\title{
EMPREGO DA ABORDAGEM SINDRÔMICA DE DOENÇAS SEXUALMENTE TRANSMISSÍVEIS, EM AMBULATÓRIO DE GINECOLOGIA DA REDE PÚBLICA DO MUNICÍPIO DE TREMEMBÉ - SP
}

\section{SANDRA IRENE SPROGIS DOS SANTOS}

Tese apresentada na área de concentração de Serviços de Saúde Pública da Faculdade de Saúde Pública da Universidade de São Paulo para obtenção do Grau de Doutor.

Área de Concentração: Serviços de Saúde Pública

ORIENTADOR: PROFa. DRa . SANDRA MARIA OTTATI DE OLIVEIRA NITRINI

São Paulo 
Autorizo, exclusivamente para fins acadêmicos e cientificos, a reprodução total ou parcial desta tese, por processos fotocopiadores.

Assinatura:

Data:

$43609 / 2003$ doc 
Aos meus filhos João Paulo, Luiz Augusto e Júlio César, com amor e carinho, dedico esta tese, por serem a razão maior da minha jornada e a luz do meu caminho... 


\section{AGRADECIMENTOS}

A Profa. Dra. Sandra Maria Otatti de Oliveira Nitrini, minha orientadora e amiga pacienciosa desde o mestrado. Ao longo desses anos, sempre esteve presente incentivando e norteando a minha criatividade com o maior empenho e profissionalismo.

Ao Secretário de Saúde do Município de Tremembé, Sr. Pedro Cunha Neto, e ao Diretor Técnico, Dr. Cláudio Ricardo Manfredini por permitirem o desenvolvimento do projeto, dando o apoio administrativo necessário.

Ao Dr. Claiton Cabral de Vasconcelos, minha maior admiração e respeito, pois, embuído de verdadeiro amor à medicina, não mediu esforços para realizar as coletas necessárias do material trabalhado nesta tese.

À enfermeira Liège Marcondes Fernandes, Sra. Dulce, Sra. Jurema, enfermeira Isabel e demais funcionários do Centro de Saúde "Dr. Carlos Borges Âncora da Luz" de Tremembé, que me receberam com atenção.

À Dra. Heloisa Maria Fileni Mendes, Diretora Técnica de Serviços de Saúde do Laboratório I - Taubaté do Instituto Adolfo Lutz, e à Dra. Regina Gomes de Almeida, Diretora da Divisão dos Laboratórios Regionais do Instituto Adolfo Lutz-São Paulo, pela inestimável colaboração para que a parte técnica deste trabalho pudesse ser desenvolvida e pela compreensão durante o periodo a que me dediquei exclusivamente a essa atividade.

Às biologistas Maria Lopes do Setor de Bacteriologia e Aguida Maria do Setor de Micologia do Instituto Adolfo Lutz de Taubaté, pela valiosa assistência no processamento microbiológico dos materiais analisados, e à Sra. Maria do Carmo Pinto Lobato e Sr. Wladimir Leme dos Santos, pelo apoio técnico.

Ás citotécnicas Rosana Pelogia Humber, Simone Ribeiro Campos Benedetti e Silvia Regina Molica Assis; à auxiliar de laboratório Rosana Naressi 
Ribeiro e ao Dr. Antonio Leônidas Coelho, responsável pelo Laboratório de Citopatologia do Vale, pela valiosa colaboração no preparo e leitura de lâminas de Papanicolaou utilizadas nesta pesquisa.

As colegas Fátima, Regina, Aracely, Sheila, pela amizade, carinho e paciência que tiveram, vivenciando comigo as alegrias e percalços dessa jornada, incentivando-me sempre, diante de tantos obstáculos por que passei no periodo.

Ao Laboratório Oswaldo Cruz de Taubaté que, na pessoa do Dr. José Domingos Abreu de Andrade, exímio conhecedor de técnicas de imunofluorêscencia para Chlamydia trachomatis, aceitou realizar os testes.

Ao Setor de Pós-Graduação da Universidade de Taubaté que investiu neste projeto, mediante bolsa de estudos concedida.

Aos consultores Prof. Dr. Carlos Roberto Chaves, Profa. Dra . Márcia Serra, Profa. Dr ${ }^{a}$. Vânia Gayer, pela inestimável orientação estatística do trabalho.

Às Profas ${ }^{2}$ Maria Elizabeth Magalhães e Ana Beatriz Rodrigues Pelogia, pelas oportunas sugestões como revisoras do texto de língua portuguesa e inglesa.

A Srt ${ }^{\mathrm{a}}$. Maria Aparecida Mendes e demais funcionários da secretaria da Comissão de Pós-Graduação da Faculdade de Saúde Pública, pela atenção dispensada.

Aos meus amigos Carmem, Jair e as minhas "norinhas" Tati e Natália, que sempre estiveram ao meu lado, dando apoio e força, nos momentos mais dificeis. De coração, fica registrada minha consideração.

A todas as mulheres, anônimas participantes deste estudo, deixo minha admiração e respeito por entenderem a relevância da pesquisa em prol da população feminina do município de Tremembé. 


\section{RESUMO}

Santos SIS. Emprego da abordagem sindrômica de doenças sexualmente transmissíveis, em ambulatório de ginecologia da rede pública do municipio de Tremembé - SP. São Paulo; 2003. [Tese de Doutorado - Faculdade de Saúde Pública da USP].

Objetivo. O estudo teve como objetivo avaliar o emprego da abordagem sindrômica de doenças sexualmente transmissíveis em mulheres que procuram um ambulatório de ginecologia da rede pública da cidade de Tremembé, com queixa clínica de corrimento e/ou para a realização do teste preventivo de Papanicolaou. Métodos. $O$ universo amostral consistiu de 105 mulheres das quais se coletou dados sociodemográficos, clínicos e amostras de secreção cérvico-vaginal, para serem submetidas às análises laboratoriais pertinentes ao diagnóstico das doenças em tela. Resultados. Cerca de $57,2 \%$ das pacientes tinham de 15 a 34 anos, sendo a maioria casada e com renda famíliar de até 2 salários mínimos. A prevalência de $T$. vaginalis foi de $1,9 \%$; C. trachomatis, 2,8\%; Candida $s p, 17,1 \%$ e vaginose bacteriana, $17,1 \%$. Nenhum caso de gonorréia foi detectado. $O$ melhor desempenho da abordagem sindrômica foi alcançado para o diagnóstico de tricomoníase e/ou vaginose bacteriana, com $95,0 \%$ de sensibilidade, $82,3 \%$ de especificidade, porém $55,9 \%$ de valor preditivo positivo. Para o diagnóstico de cervicite por $C$. trachomatis, a sensisibilidade foi de $66,7 \%$; especificidade de $83,3 \%$ e valor preditivo positivo de $10,5 \%$. Em relação aos escores de risco avaliados no estudo, tiveram associação estatisticamente significativa para infecção por $C$. trachomatis o número de parceiros sexuais e a cor do corrimento "amarelo ou outro". Conclusões. A aplicação da abordagem sindrômica mostrou ser ferramente útil para o diagnóstico de doenças sexualmente transmissíveis, além de identificar um número expressivo de verdadeiros casos negativos, diminuindo a possibilidade de tratamentos desnecessários.

Descritores: Abordagem sindrômica.

Doenças Sexualmente Transmissíveis.

Corrimento cérvico-vaginal. 


\section{SUMMARY}

Santos SIS. Emprego da abordagem sindrômica de doenças sexualmente transmissíveis em ambulatório de ginecologia da rede pública do municipio de Tremembé - SP. [Application of the syndromic management for sexually transmitted diseases at a public gynecological ambulatory in the town of Tremembé, SP-Brazi]. São Paulo (BR); 2003. [PhD Thesis - Faculdade de Saúde Pública da Universidade de São Paulo Brazil].

Objectives. The present study aimed at assessing the application of the syndromic management to STD in women who had a clinical complaint of vaginal discharge and/or carried out the Papanicolaou preventive test. Methods. The sampling consisted of 105 women from whom sociodemographical and clinical data have been collected, besides cervicalvaginal discharge samples to undergo laboratory analysis related to the associated diseases. Results. Virtually $57.2 \%$ of the patients ranged from ages 15 to 34 years old and most were married bearing a family monthly income of around $\$ 130.00$. The prevalence of $T$. vaginalis accounted for $1.9 \%$; C. trachomatis, $2.8 \%$; Candida $\mathrm{sp}, 17.1 \%$ and bacterial vaginosis, $17.1 \%$. No case of gonorrhea has been detected. The best performance of syndromic management was achieved for the diagnosis of bacterial vaginosis and/or tricomoniasis, with $95.0 \%$ sensitivity and $82.3 \%$ specificity. Nonetheless, a $55.9 \%$ positive predictive value was detected. For the diagnosis of $C$. trachomatis cervicitis the values were $66.7 \%$ sensitivity, $84.3 \%$ specificity and $11.1 \%$ positive predictive value. As for risk scores assessed in the study, the number of sexual partners and the color of the discharge "yellow or other" had a statistically significant association to $C$. trachomatis infection. Conclusions. The application of the syndromic management has demonstrated to be a useful tool for the diagnosis and treatment of Sexually Transmitted Diseases, as well as for the identification of a considerable number of true negative cases, which may contribute to a decrease in unnecessary treatments.

Key words: Syndromic management

Sexually Transmitted Diseases (STD)

Vaginal discharge 


\section{ÍNDICE}

\section{INTRODUÇÃO}

pg.

1.1 Aspectos Epidemiológicos

1

1.2. Histórico das DST

1.3. A importância das DST em mulheres

1.3.1. Aspectos anatômicos e histofisiológicos do trato genital inferior feminino

1.3.1.1. Secreção vaginal fisiológica

1.3.1.2. Flora vaginal normal

1.3.2. Comimento vaginal

1.3.3. Vulvovaginites

1.3.3.1. Vaginose bacteriana

1.3.3.2. Candidiase vulvovaginal

1.3.3.3. Tricomoníase vaginal

1.3.4. Cervicites

1.4. Abordagem Sindrômica $\quad 26$

\section{OBJETIVOS}

2.1. Principal 32

2.2. Específicos 32

3. METODOLOGIA 33

3.1. Avaliação do piloto 33

3.2. Amostra 33

3.2.1. Critérios de inclusão 34

3.2.2. Critérios de exclusão $\quad 34$

3.3. Coleta de dados 35

3.3.1. Dados demográficos e história clínica

3.3.2. Exame clínico ginecológico 35

3.3.2.1. Coleta de esfregaço cérvico-vaginal 35

3.3.2.2. Coleta de material para pesquisas microbiológicas $\quad 36$

3.3.2.3. Testes realizados durante a consulta 37

3.4. Utilização do algoritmo para corrimentos vaginais, proposto pelo 38 Ministério da Saúde

3.5. Encaminhamento do material ao laboratório 38

3.6. Procedimentos laboratoriais $\quad 38$

3.6.1. Pesquisa de Chlamydia trachomatis 38

3.6.2. Cultura de Neisseria gonorrhoea 39 
3.6.3. Cultura e identificação de leveduras $\quad 39$

3.6.3.1. Técnica do tubo germinativo $\quad 40$

3.6.3.2. Pesquisa de clamidósporo $\quad 40$

3.6.4. Bacterioscopia $\quad 40$

3.6.4.1. Exame direto "a fresco" $\quad 40$

3.6.4.2. Coloração de Gram 41

3.6.5. Teste de Papanicolaou 41

3.6.6. Parâmetros e critérios para a leitura do material 41

3.6.6.1. Exame direto "a fresco" 41

3.6.6.2. Esfregaço endocervical corado pelo Gram 42

3.6.6.3. Esfregaço de fundo de saco vaginal corado pelo Gram $\quad 42$

3.6.6.4. Esfregaço de Papanicolaou 43

3.7. Processamento e análise dos dados 44

4. RESULTADOS 45

4.1. Caracteristicas sociodemográficas 46

4.2. Histórico gineco-obstétrico e comportamental 48

4.3. Avaliação clínica, diagnóstico e tratamento 53

4.4. Resultados das análises laboratoriais $\quad 60$

4.5. Análise estatística 65

4.5.1. Prevalência, Sensibilidade, Especificidade e Valor Preditivo Positivo

4.5.2. Escores de Risco

72

4.5.2.1. Avaliação do perfil sóciodemográfico, comportamental e clínico-laboratorial como risco para mulheres com DST

4.5.2.2. Avaliação do perfil sócio demográfico, comportamental e clínico-obstétrico como fator de risco para mulheres com vaginose bacteriana ou candidiase

5. DISCUSSÃO

6. CONCLUSÕES

7. REFERÊNCIAS BIBLIOGRÁFICAS

ANEXO 1. Algoritmo para abordagem sindrômica de corrimentos (MINISTÉRIO DA SAÚDE, 1999)

ANEXO 2. Consentimento Informado

ANEXO 3. Protocolos padronizados

ANEXO 4.Quadro 1. Causas de vaginites

Quadro 2. Comparação dos sistemas de escores, desenvolvidos por Nugent e Spiegel para o diagnóstico de vaginoses bacterianas, empregando-se o método de Gram. 


\section{ÍNDICE DE TABELAS}

Tabela 1. Características socioeconômicas e demográficas das mulheres que procuraram o Centro de Saúde de Tremembé, no período de setembro a novembro de 2002, com queixa clínica de corrimento e/ou para realização do preventivo de Papanicolaou. Tremembé, 2002.

pg.

Tabela 2. Histórico gineco-obstétrico das 105 mulheres.Tremembé, 2003.

Tabela 3. Características comportamentais e de risco para DST de 105 mulheres. Tremembé, 2003.

Tabela 4. Histórico de DST de 105 mulheres. Tremembé, 2003

Tabela 5. Motivos da consulta ginecológica referidos pelas 105 mulheres. Tremembé, 2003.

Tabela 6. Histórico do exame preventivo de Papanicolaou de 105 mulheres. Tremembé, 2003

Tabela 7. Achados clínicos no colo uterino de 105 mulheres. Tremembé, 2003.

Tabela 8. Leucorréia em 105 pacientes. Tremembé, 2003.

Tabela 9. Resultados dos testes realizados no consultório e escore de risco de 105 mulheres. Tremembé, 2003

Tabela 10. Diagnóstico clínico de 105 mulheres. Tremembé, 2003

Tabela 11. Medicamentos prescritos para o tratamento de 60 pacientes. Tremembé, 2003

Tabela 12. Resultados do exame direto "a fresco" de secreção vaginal de 105 pacientes. Tremembé, 2003.

Tabela 13. Resultados das análises laboratoriais de esfregaços corados pelo método de Gram, obtidos de 105 mulheres. Tremembé, 2003.

Tabela 14. Resultados microbiológicos obtidos em secreções cérvicovaginais de 105 mulheres. Tremembé, 2003.

Tabela 15. Resultados da avaliação oncótica das secreções cérvicovaginais coradas pela técnica de Papanicolaou de 105 mulheres. Tremembé, 2003.

Tabela 16. Resultados da avaliação microbiológica das secreções cérvico-vaginais coradas pela técnica de Papanicolaou das 105 mulheres. Tremembé, 2003. 
Tabela 17. Resultados da leitura complementar realizada em esfregaços corados por Papanicolaou de 105 mulheres, para indicação de cervicite. Tremembé, 2003.

Tabela 18. Taxa de prevalência de agentes causais associados a corrimento vaginal em 105 mulheres. Tremembé, 2003.

Tabela 19. Distribuição do número e percentual de diagnósticos etiológicos dos agentes em estudo e associações, na secreção cérvico-vaginal de 105 mulheres, obtidos pelos métodos considerados padrão "ouro", na abordagem sindrômica, Papanicolaou e Gram. Tremembé, 2003

Tabela 20. Distribuição dos percentuais de sensibilidade (S), especificidade (E) e valor preditivo positivo (VPP) dos diagnósticos de corrimentos vaginais de 105 mulheres, realizados empregando-se a abordagem sindrômica, método de Papanicolaou, método de Gram e exame direto "a fresco". Tremembé, 2003.

Tabela 21. Sensibilidade (S), especificidade (E), valor preditivo positivo (NPP) e razão de proporções (ODDS) com nível de significância $(p)$ de $95 \%$ dos critérios indicadores de cervicite em esfregaços corados pelo método de Papanicolaou. Tremembé, 2003.

Tabela 22. Associação univariada de DST com variáveis de comportamento e clínicas de 105 mulheres. Tremembé, 2003.

Tabela 23. Sensibilidade (S), especificidade (E) e valor preditivo positivo (VPP) dos escores de risco originalmente propostos pelo Ministério da Saúde (MS) e os sugeridos no estudo. Tremembé, 2003.

Tabela 24. Sensibilidade (S), especificidade (E) e valor preditivo positivo (VPP) dos escores de risco originalmente propostos pelo Ministério da Saúde (MS) associados aos escores sugeridos no estudo. Tremembé, 2003.

Tabela 25. Associação univariada de vaginose bacteriana e candidiase com variáveis de comportamento e clínicas de 105 mulheres. Tremembé, 2003. 
ÍNDICE DE FIGURAS

pg

Figura 1. Fluxograma das 105 pacientes participantes do estudo 


\section{INTRODUÇÃO}

O controle das doenças sexualmente transmissiveis (DST), tem sido considerado mundialmente como um desafio, no âmbito da saúde pública. Fatores biológicos, socioeconômicos e comportamentais estão vinculados às modificações do perfil epidemiológico dessas infecções, remetendo a um quadro de relevante magnitude e transcendência.

Em franca epidemia, a Síndrome da Imunodeficiência Humana Adquirida (AIDS) resgata, nas duas ultimas décadas, o olhar da comunidade científica para as DST, destacando, em diversos estudos, o estreito relacionamento desses agravos com o aumento da susceptibilidade à infecção pelo vírus da imunodeficiência humana (HIV), além das conseqüências, que, direta ou indiretamente, resultam em gastos elevados em tratamentos e da repercussão social de tais eventos (CDC 2000; AIDSCAP 1998). Atualmente, são conhecidas mais de 15 entidades etiológicas de natureza bacteriana, viral, parasitária ou micótica que têm como característica essencial, porém não indispensável, a transmissão pelo coito. Assim, patógenos como Chlamydia trachomatis, Trichomonas vaginalis, Treponema palidum, Neisseria gonorrhoeae destacam-se ou pela importância clínica ou pela prevalência (VALDIVIA-BLONDET e ESCALANTE-JIBAJA 2000).

Enquanto as DST de origem viral, tais como as infecções causadas pelo HIV, Papilomavírus Humano (HPV), Hepatite B (HBS) ou Herpes vírus (HSV), são condições crônicas incuráveis, muitas das conseqüências e seqüelas das infecções não-viróticas podem ser evitadas e tratadas, reduzindo o periodo de infectividade e, conseqüentemente, o risco de adquirir AIDS (CDC 1998, CATCHPOLE 2001). 
Verifica-se, ainda, que principalmente a incidência das DST bacterianas é determinada, por um lado, pelo comportamento sexual dos indivíduos e, por outro, pela acessibilidade, aceitabilidade e eficácia dos serviços de saúde no diagnóstico precoce e tratamento. Ambos os fatores são radicalmente modificados por alterações político-econômicas, que geram pobreza e desemprego, afetando especialmente as mulheres (CARDOSO 2002).

Assim, o controle desses agravos, empregando-se os princípios básicos epidemiológicos da interrupção da cadeia de transmissão, detectando e tratando precocemente, tanto os casos, como os parceiros sexuais e prevenindo novas ocorrências, por meio de aconselhamento específico na adoção de práticas sexuais mais seguras, não tem sido tarefa fácil, até mesmo nos países desenvolvidos (WHO 2001b).

\section{1. ASPECTOS EPIDEMIOLÓGICOS}

A Organização Mundial de Saúde (OMS) estimou, em 1999, 340 milhões de novos casos mundiais de síflis, gonorréia, infecções por Chlamydia trachomatis e tricomoniase, atingindo homens e mulheres na faixa etária de 15 a 49 anos. Essas infecções têm prevalência mais elevada na África Subsaariana, onde a incidência combinada é de 254 casos por 1.000 indivíduos da população de risco. As DST estão entre as cinco principais causas de procura por serviços de saúde (MINISTÉRIO DA SAÚDE 1999), e as de etiologia bacteriana representam o segundo lugar das doenças tratáveis nas mulheres entre os 15 e os 44 anos de idade (WHO 2001b).

Segundo estimativas da Organização Mundial de Saúde, ocorrem no Brasil cerca de 12 milhões de DST ao ano. No entanto, apenas 200.000 casos são notificados, evidenciando que os indicadores epidemiógicos nem sempre expressam a realidade do pais (MINISTÉRIO DA SAÚDE 2002). 
Estimativas de prevalência das DST para 2001, realizadas pela UNAIDSMHO (2002), a partir de dados obtidos de referenciais brasileiros no âmbito nacional, regional e local, apontaram o vírus HPV como o mais prevalente entre as DST analisadas, representando $15,17 \%$ de casos. A sífilis contribuiu com $2,06 \%$ do total, a tricomoniase com $1,92 \%$, o virus HSV com $0,76 \%$ e a gonorréia de $0,71 \%$.

Recentemente, a imprensa nacional publicou nota em documento eletrônico (FORMENTI 2002), informando que fontes do Ministério da Saúde afirmaram que um em cada seis brasileiros é portador de uma doença sexualmente transmissível, o que corresponde a cerca de 30 milhões de pessoas, sendo que $80 \%$ são mulheres assintomáticas.

Diante dessa divergência de informaçöes, fica evidente a fragilidade do sistema de vigilância das DST e a falta de priorização dessas doenças em diversos níveis do sistema de saúde.

Segundo o MINISTÉRIO DA SAÚDE (2002), a deficiência nas tecnologias laboratoriais para um diagnóstico conclusivo, suficientemente sensivel e especifico para muitas das DST, somada ao fato que raras são as Unidades de Saúde que dispõem de testes no momento da consulta e a irregularidade na disponibilização de medicamentos contribuem tanto para o afastamento dos pacientes do serviço de saúde, como também propiciam que os clínicos, por insegurança na realização do diagnóstico com base apenas em sinais e sintomas, notifiquem a doença (MINISTÉRIO DA SAÚDE 1999, HYPPÓLITO 1996, MOHERDAUI e col. 1998).

Por outro lado, o estigma social imposto por esses agravos, muitas vezes, não conduz o seu portador à busca de serviços de saúde e sim, leva-o a procurar formas alternativas de tratamento por meio do aconselhamento com balconistas de farmácia ou de outros modos informais e rápidos, resultando, assim, não só na distorção do sistema de vigilância 
epidemiológica, subestimando substancialmente os indicadores epidemiológicos, mas também no fortalecimento de mecanismos de resistência bacteriana pelos tratamentos inadequados (WHO 2001a).

Outro fator relevante que contribui para a escassez de dados epidemiológicos em nosso meio é que apenas a AIDS e a sífilis congênita são doenças de notificação compulsória (MINISTÉRIO DA SAÚDE 1998b).

\section{2. HISTÓRICO DAS DST}

As DST acompanham a história da humanidade, com provas evidentes, tanto nos excertos bíblicos, como nos escritos dos povos do Extremo-Oriente, dos gregos e dos romanos, onde já eram conhecidas doenças relacionadas com o contato sexual, que, no tempo da Grécia antiga, foram chamadas de doenças venéreas, como referência a Vênus, a Deusa do Amor (CARDOSO 2002).

Sem dúvida, a gonorréia ou blenorragia é uma das doenças mais antigas, da qual foram encontradas referências em escritos do imperador chinês Huang Ti de 2637 a.C., bem como alusões aos sintomas no Antigo Testamento, chegando à Idade Média já com as descrições clássicas das manifestações da doença (SECRETARIA DE ESTADO DA SAÚDE DE SÃO PAULO 1989).

Em obras médicas chinesas do século VII a.C., existem descrições de lesões ulcerosas dos genitais, certamente de origem sifilitica e as descrições bíblicas da peste de Moah, que, seguramente, correspondem à sifilis. Pinturas do Leste Europeu, conservadas em Cracóvia e anteriores ao descobrimento da América, retratam uma afecção que evoluía por surtos, correspondendo, muito provavelmente, à sífilis. Em resumo, parece evidente a existência de sífilis no Velho Mundo, embora não tenha sido muito 
freqüente até o século $\mathrm{XVI}$, quando ocorreu uma epidemia sifilitica (CARDOSO 2002).

As primeiras descrições da doença devem-se a Marcellus Cumanus e Alexander Benedictus, que tiveram oportunidade de observar a ocorrência de sífilis, durante a batalha de Formino. Uma descrição clínica completa foi publicada em 1530, por Jerônimo Fracastori, num poema intitulado "Syphilis sive Morbus Gallicus". A partir do século XVI, a sifilis difundiu-se rapidamente na Europa e, durante dois séculos, foi considerada a única doença venérea (BELDA $1985 \mathrm{a}$ b).

$\mathrm{Na}$ idade Média as doenças venéreas acometiam democraticamente o povo, clero e nobreza, segundo os relatos daquele tempo, deixando evidente a conotação estigmatizante, pela associação dessas doenças ao imoral, proibido e ao possível relacionamento com prostituição ou promiscuidade sexual.

A partir da segunda metade de séc. XIX, com o advento do microscópio, agentes etiológicos das doenças venéreas mais conhecidas foram observados, e a descrição de um método de coloração por Christian Gram, em 1884, contribuiu decisivamente para a "Era Microbiológica". A partir dessa nova técnica laboratorial, passou-se a caracterizar as bactérias em dois grandes grupos: Gram-positivas e Gram-negativas, devido às características dos constituintes da parede celular bacteriana (BIER 1994).

No início do séc. $X X$, era crescente o conhecimento a respeito dos agentes causais das doenças venéreas, como também sua incidência, o que invocou medidas de saúde pública por parte dos governantes, principalmente a partir da eclosão da primeira Guerra Mundial. Naquela época, já eram bem definidas, clínica e etiologicamente, a sífilis, a gonorréia, o cancro mole, o linfogranuloma venéreo e a donovanose. 
Caracterizavam-se, assim, as doenças venéreas como de sintomatologia inicial predominantemente na genitália, transmissão fundamentalmente pelo coito, freqüência maior na população masculina dos 20 aos 30 anos e com estreito relacionamento com a prostituição (BELDA 1991, SECRETARIA DE ESTADO DA SAÚDE 1989).

A genial descoberta da penicilina por Fleming, em 1922 e sua eficácia contra Treponema pallidum e o gonococo, permitiram obter a primeira grande vitória sobre estas doenças venéreas, de tal modo que muitos acreditaram que elas estariam erradicadas do mundo. Essa crença levou à desativação de ambulatórios públicos de venereologia, e também o ensino de doenças venéreas nas faculdades de medicina foi negligenciado, por volta de 1950 (SECRETARIA DE ESTADO DA SAÚDE DE SÃO PAULO 1989).

A revolução cultural, por volta de 1960, induziu em âmbito geral, à uma liberação de costumes e particularmente, expressiva em relação às mulheres, com o advento da pilula anticoncepcional. Paralelamente, uma série de movimentos sociais emergiram, como: a legalização do aborto, a organização dos homossexuais em grupos, lutando por direitos legais e sociais, dando nova dimensão à sexualidade humana, que até então era mantida velada na maioria da sociedades.

Em 1979, foi descrito, nos Estados Unidos, o aparecimento de febre prolongada em pacientes adultos jovens, homossexuais, que desenvolviam doenças pouco comuns, como pneumonia por Pneumocistys carinii e sarcoma de Kaposi, apresentando importante comprometimento imunológico. Concluiu-se que se tratava de doença ainda não classificada, de etiologia provavelmente infecciosa e de possivel transmissão sexual, e que, em 1982, passa a ser conhecida como Acquired Immunodeficiency Syndrome - AIDS (Síndrome da Imunodeficiência Adquirida) (MINISTÉRIO DA SAÚDE 1999). 
Nessas últimas décadas, observou-se que, além da AIDS, um novo grupo de doenças ligadas por um traço comum, ou seja, possivel transmissão sexual, caráter epidêmico e características epidemiológicas diversas, crescia ao lado do recrudescimento das doenças venéreas clássicas. Estas compreendiam infecções pelos vírus HSV, HPV e da hepatite $B$, o molusco contagioso, os corrimentos genitais não gonocócicos, a escabiose, a pediculose púbis, entre outras (BELDA 1991).

Ao longo das décadas de 80 e 90 , o mundo assistia a convulsões políticas, sociais e culturais globalizadas, as quais, refletindo na economia dos países em desenvolvimento, apresentavam como denominador comum o empobrecimento das populações.

Ao mesmo tempo, a epidemia do HIV avançava a partir de inúmeros contextos ambientais, culturais e sociais, revelando sua ação letal, sem perspectiva terapêutica, o que gerou pânico social e, conseqüentemente, trouxe novas modificações na sexualidade humana que trocou, então, o sexo pela drogadição que, por sua vez, leva à prostituição (FERNANDES e col. 2000).

Em comunidades menos favorecidas, os programas de controle bem sucedidos enfrentam problemas, tais como pobreza, desigualdades de gênero, emigração e violência, que contribuem para o aumento da epidemia de HIV (PATH/UNFPA 2001).

Nos últimos anos, importantes mudanças vêm ocorrendo no perfil epidemiológico da AIDS que, no início, caracterizava-se pela transmissão entre homens homossexuais ou bissexuais, de escolaridade elevada, passando gradativamente a se caracterizar pela transmissão sangüínea, especialmente entre usuários de drogas injetáveis, associando-se à um processo de pauperização, interiorização e atualmente de feminilização, uma vez que a pandemia de AIDS tem evidenciado um número cada vez maior 
de mulheres, que são infectadas através de relações heterossexuais (MINISTÉRIO DA SAÚDE 1999, PATH/UNFPA 2001).

\section{3. A IMPORTÂNCIA DAS DST EM MULHERES}

Verifica-se que é sobre a população feminina que esse grupo de doenças causam maior impacto, seja pelo aumento da prevalência da infecção pelo HIV, seja pela gravidade das complicações e seqüelas geradas, tais como: infertilidade; gravidez ectópica; doença inflamatória pélvica (DIP); aborto espontâneo; câncer de colo uterino; infecções neonatais, dentre outras (CASTLE e col. 2001, DAVIES e PATRUNO 2000, JIMÉNEZ e col. 2201, FERNANDES e col. 2000). Um agravante da maioria dessas condições é que a sintomatologia pode estar presente ou não, sendo que cerca de $70 \%$ dos casos de infecções gonocócicas ou por $C$. trachomatis em mulheres podem ser assintomáticas (ONUSIDA 1998).

Vários estudos, como o de PERLMAN e col. (1998) reportam a alta prevalência de DST em populações jovens associadas a relevantes indices de morbi-mortalidade, destacando o HPV, com vários sorotipos diretamente relacionados à gênese do câncer de colo uterino.

Sob o ponto de vista cultural, as ações preventivas visando ao aconselhamento dificilmente são alcançadas, pois, na maioria das sociedades, a mulher tem pouco ou nenhum controle quanto às decisões relativas a quando e sob quais condições ter relações sexuais ou em relação ao uso do condom pelo parceiro, e, menos ainda, das condutas sexuais dele (van DAM 1995, JIMENEZ e col. 2001). 


\subsubsection{Aspectos anatômicos e histofisiológicos do trato genital inferior feminino}

Por trato genital inferior entende-se o segmento do aparelho genital feminino que engloba a vulva, as glândulas Skene e de Bartholin, a vagina e o colo, até a junção escamo-colunar. A vulva é formada pelos grandes e pequenos lábios, pelo clitóris, pelo vestibulo, onde se abrem os orificios das glândulas vestibulares e também a vagina e a uretra.

A parede vaginal é desprovida de glândulas, exibindo mucosa flexível, brilhante, rosada, estriada com pregas, revestida por epitélio estratificado escamoso e ricamente vascularizada, o que leva à produção de um transudato que auxilia na lubrificação vaginal. Essa mucosa passa por modificações devido ao ciclo menstrual que, sob estímulo estrogênico, faz com que o epitélio sintetize e acumule grande quantidade de glicogênio que é lançado na luz vaginal, quando as células epiteliais descamam (GARDNER e col. 1988).

O colo uterino é a porção estreita e cilíndrica do útero que faz saliência no fundo da vagina, recoberto externamente pelo mesmo tipo de epitélio da vagina e constitui a ectocérvice. A endocérvice, por sua vez, corresponde à mucosa da luz do colo uterino composta pelo epitélio colunar simples de células mucinógenas, o qual se apoia em lâmina própria rica em glândulas mucosas cervicais, responsáveis pela produção do muco, desempenhando papel importante na fertilização (TAKAHASHI 1982).

\subsubsection{Secreção vaginal fisiológica}

A cavidade vaginal é fisiologicamente úmida, isto é, contém o produto de secreção das glândulas sebáceas, sudoríparas, vestibulares e endocervicais, além da transudação da mucosa vaginal, e, todos esses 
elementos, misturados com células epiteliais descamadas. O conteúdo vaginal altera-se com a idade, em decorrência de influências hormonais, estímulo sexual e fatores psíquicos, o que explica a natural variação individual na sua qualidade e quantidade (EGAN e LIPSKY 2000, POZO e col. 2000).

Segundo EGAN e LIPSKY (2000), HALBE (2000), DAVIES e PATRUNO (2000) o conteúdo vaginal normal, geralmente, tem $\mathrm{pH} \leq 4,5$, é inodoro, de coloração branca ou ligeiramente castanha, tem aspecto flocular e pouca quantidade, não fluindo ao exame especular. Quando seca, pode adquirir a cor amarelada devido aos pigmentos presentes, principalmente de origem bacteriana. $\mathrm{O}$ colo do útero secreta muco de aspecto translúcido, sendo um dos principais componentes da secreção vaginal, principalmente no meio-ciclo, pela influência dos estrógenos, quando se torna mais abundante e fluido.

\subsubsection{Flora vaginal normal}

Em 1894, Döderlein constatou a predominância de um grupo de bacilos anaeróbios facultativos, Gram-positivos, na flora normal de mulheres em idade reprodutiva, conhecidos também como bacilos de Döderlein, os quais, atualmente, são classificados no gênero Lactobacillus (VALLOR e col. 2001).

Posteriormente, outros bacilos anaeróbios, geralmente Gramnegativos pertencentes aos gêneros Bacteroides e Fusobacterium; cocos Gram positivos dos gêneros Peptococcus e Peptostreptococcus; e bacilos Gram positivos dos gêneros Propionibacterium, Bifidobacterium e Actinomyces também foram reconhecidos como componentes normais da flora vaginal. Portanto, a microbiota vaginal de mulheres saudáveis é composta de uma grande variedade de bactérias aeróbias e anaeróbias, com predominância dos Lactobacillus spp, representando cerca de $10^{7}$ a $10^{8}$ 
CFU/g (unidades fromadoras de colônias por grama) do conteúdo vaginal, os quais mantêm uma inter-relação dinâmica (EGAN e LIPSKY 2000, MENDES 1991).

Os lactobacilos possuem propriedades de antagonismo microbiano e produzem vários metabólitos que são importantes na manutenção da microbiota normal da região vaginal. Quando o epitélio descama, sob influência hormonal, o glicogênio lançado no canal vaginal é degradado à glicose, por enzimas de células epiteliais e dos lactobacilos. A glicose, por sua vez, é fermentada pelos lactobacilos, resultando no ácido lático como produto final, o qual contribui para a manutenção de um pH entre 4,0 e 4,5. Algumas espécies são também produtoras de peróxido de hidrogênio, substância de poder oxidante e com grande atividade antimicrobiana, enquanto outras produzem bactericinas ou surfactantes com atividade similar (HALBE 2000, ROSSI e col. 2000, LARSEN e MONIF 2001).

As espécies de lactobacilos mais comuns incluem $L$. acidophilus e L. fermentum, e os menos freqüentes são $L$. plantarum, $L$. brevis, $L$. jensenii, $L$. casei, $L$. delbrueckii, e $L$. salivarius, sendo que mais de uma espécie pode ser encontrada num mesmo indivíduo, e variação das espécies mais prevalentes também são referidas (LARSEN e MONIF 2001, VALLOR e col. 2001, ANTONIO e col. 1999).

De acordo com van DAM (1995), a área de exposição da mucosa cérvico-vaginal, por ser relativamente ampla, torna a mulher mais vulnerável a infecções por diversos agentes, inclusive o HIV, mas, por outro lado, nos diversos estudos realizados com lactobacilos, fica evidente que essas bactérias também exercem um importante fator de proteção, não só para infecção do HIV, como também para gonorréia e vaginose bacteriana. 


\subsubsection{Corrimento vaginal}

A percepção do corrimento varia entre as mulheres, algumas podendo apresentar secreção abundante, mesmo sem queixa clínica. $O$ corrimento vaginal, também chamado de leucorréia, é um sintoma que indica a presença de secreção vulvovaginal excessiva ou anormal (HALBE 2000). As causas são geralmente de natureza inflamatória ou de outros fatores de caráter biológico ou não, como mostra o anexo 4 , com possibilidade de ocorrer associações entre os fatores causais.

As colpites ou vaginites são as causas mais comuns do corrimento vaginal e geralmente estão associadas com as cérvico-colpites e vulvites. $\mathrm{Na}$ prática, o processo inflamatório não se limita a uma só região, tendo em vista a solução de continuidade da área, portanto, as vaginites estão normalmente associadas às vulvites $e$, nesse caso, a denominação é vulvovaginite (FERNANÁNDEZ e LOMBARDIA 2001, HALBE 2000).

\subsubsection{Vulvovaginites}

Segundo o MINISTÉRIO DA SAÚDE (1999), considera-se como vulvovaginite toda manifestação inflamatória e/ou infecciosa do trato genital feminino inferior, ou seja, vulva, vagina e epitélio escamoso do colo uterino (ectocérvice).

Os sintomas podem aparecer isolados ou associados e, de modo geral, são representados por corrimento, sensação de desconforto hipogástrico, prurido de intensidade variável, disúria e dispareunia.

Dentre as vulvovaginitis de maior importância clínica destacam-se: 


\subsubsection{Vaginose bacteriana}

Segundo CANTO-DE CETINA e col. (2002), ROSSI e col. (2000), a vaginose bacteriana, em todo o mundo, é a mais freqüente das vulvovaginites nas mulheres em idade reprodutiva e sexualmente ativas. Tanto nos Estados Unidos como em nosso meio, são diagnosticadas cerca de $18 \%$ a $23 \%$ das mulheres atendidas em clínicas de planejamento familiar, correspondendo a $45 \%$ de todos os casos de corrimentos vaginais.

A importância da vaginose bacteriana não se limita apenas à sua elevada freqüência, podendo também levar ao desencadeamento de complicações obstétricas, como: corioamnionite; amniorrexi; trabalho de parto prematuro; endometrite puerperal; abcessos pélvicos; salpingites; infecções pós-operatórias e infecções do trato urinário. Alguns estudos têm evidenciado, sua possível associação à neoplasia cervical intra-epitelial e, mais recentemente, também ao vírus HIV (CASTLE e col. 2001, CHECA e SÁNCHEZ 2001, CANTO-DE CETINA e col. 2002).

Por outro lado, vários fatores de risco predispõe à vaginose bacteriana: múltiplos parceiros sexuais, uso de dispositivo intra-uterino e presença de outras DST. Embora diversos estudos apontem sua relação com a atividade sexual, ela não é considerada uma DST, posto que não está claro se é adquirida por um agente transmitido sexualmente, uma vez que houve constatação da presença daquelas bactérias em mulheres virgens (ROSSI e col. 2000, POZO e col. 2000)

Conceitualmente, a vaginose bacteriana é caracterizada por um desequilíbrio da flora vaginal normal, devido a um aumento exagerado de Gardnerella vaginalis; espécies de Mobiluncus; Mycoplasma hominis; algumas espécies de bactérias Gram-negativas anaeróbias, pertencentes ao gênero Prevotella, Porphyromonas, Bacteróides sp, e ainda, distintas espécies de peptoestreptococos, dentre outras. A causa provável dessa 
proliferação ainda é desconhecida (CANTO-DE CETINA e col. 2002, CHECA e col. 2001, ROSSI e col. 2000, EGAN e LIPSKY 2000, POZO e col. 2000, DAVIES E PATRUNO 2000).

Esse aumento é associado à ausência ou à diminuição acentuada dos lactobacilos acidófilos, porém sem desencadear uma resposta inflamatória significativa, o que implica a escassez ou ausência de leucócitos. Assim, ao longo dos anos desde sua descoberta, houve um consenso em classificar o processo como uma vaginose e não vaginite como inicialmente era conhecida (POZO e col.2000, DAVIES e PATRUNO 2000).

Clinicamente, quase metade das mulheres com vaginose bacteriana é completamente assintomática. $O$ corrimento, quando presente, é de cor acinzentada, de aspecto homogêneo, algumas vezes bolhoso, com odor fétido, e referido como mais acentuado depois do coito e no periodo menstrual, com ou sem dispareunia (MINISTÉRIO DA SAÚDE 1999).

Por muito tempo, o diagnóstico foi motivo de controvérsia, mas atualmente, os critérios estabelecidos por Amsel e colaboradores, descritos por NAVARRRETE e col. (2000), EGAN e LIPSKY (2000), ROSSI e col. (2000), são aceitos mundialmente e baseiam praticamente em elementos clínicos, diagnosticando, dessa forma, mais de $90 \%$ dos casos. Assim, a vaginose bacteriana é reconhecida quando pelo menos três dos quatro critérios descritos abaixo estiverem presentes (ROSSI e col. 2000):

1. alteração do conteúdo vaginal: presença de secreção acinzentada, esbranquiçada ou amarelada, fluida, homogênea, recobrindo as paredes vaginais; 
2. medida do $\mathrm{pH}$ vaginal superior a 4,5: avalia-se por meio de uma fita de nitrazida em contato com secreção depositada no espéculo vaginal ou coletada no fundo de saco vaginal;

3. teste das aminas positivo: liberação de odor fétido quando uma amostra da secreção vaginal é misturada com uma gota de hidróxido de potássio a $10 \%$ (whiff test) - sugere a presença de anaeróbios, devendo-se às aminas biovoláteis (cadaverina, putrescina e trimetilamina), cujo odor se assemelha ao peixe podre;

4. presença de clue cells ou células-guia (mais de $20 \%$ ) em exame "a fresco" da secreção vaginal com soro fisiológico: correspondem a células epiteliais totalmente tomadas pelas bactérias, conferindo um contorno irregular ou granular ao citoplasma.

Outros pesquisadores como Nugent e Spiegel, citados por NAVARRRETE e col. (2000), EGAN e LIPSKY (2000), desenvolveram parâmetros para o diagnóstico de vaginose bacteriana, tendo empregado testes laboratoriais simples, aplicando o método de Gram em esfregaços vaginais. A leitura semi-quantitativa da lâmina é realizada com o uso de um sistema de escores, pontuando a presença de lactobacilos, G. vaginalis e outros morfotipos bacterianos Gram-variáveis ou Gram-negativos e, também, a presença de clue cells, como descrito no anexo 4.

O método de Papanicolaou, embora não seja recomendado para o diagnóstico de vaginose bacteriana devido à baixa sensibilidade, serve para excluí-la, em razão da alta espeficidade (AVILÉS 2001).

As principais alterações citológicas consistem na escassez de lactobacilos e leucócitos, alterações nucleares pouco evidentes e na presença de clue cells. Estas representam células epiteliais vaginais ou 
ectocervicais descamadas, intensamente parasitadas em sua superfície pela Gardnerella sp ou Mobiluncus sp, que thes confere aspecto granuloso característico (TAKAHASHI 1982, GIRALDO e col. 2002).

A cultura de secreção vaginal não é indicada, devido à característica polimicrobiana da vaginose bacteriana. Além disso, a $G$. vaginalis é um componente da flora normal endógena e está presente em mais de $55 \%$ mulheres normais. Alguns ensaios referentes a produtos bacterianos como 0 ácido succínico, por exemplo, estão sendo desenvolvidos, porém não estão incorporados à prática clínica. (ROSSI e col. 2000)

Quanto à terapêutica medicamentosa, as drogas de eleição representam os nitro-imidazólicos, tais como: metronidazol, tinidazol, secnidazol ou ainda, clindamicina ou tianfenicol, administrados via oral ou por aplicação tópica (MINISTÉRIO DA SAÚDE 1999). Os índices de cura são superiores a $90 \%$, e a via oral confere uma rápida absorção e elevada biodisponibilidade. Quanto ao parceiro, o tratamento é recomendado só nos casos de recidivas, embora haja controvérsias sobre este procedimento (ROSSI e col. 2000, HALBE 2000).

\subsubsection{Candidiase vulvovaginal}

É uma infecção da vulva e vagina, causada por um fungo comensal que habita tanto a mucosa vaginal quanto a mucosa digestiva e que cresce quando o meio se torna favorável para o seu desenvolvimento (MINISTÉRIO DA SAÚDE 1999).

A candidíase corresponde à segunda causa mais freqüente de vulvovaginite, e estima-se que $75 \%$ das mulheres terão ao menos um episódio ao longo de sua vida. Cerca de $40 \%$ a $50 \%$ das mulheres 
apresentariam uma segunda infecção e, em $5 \%$ dos casos, a candidíase adquire um padrão crônico com recorrências freqüentes de quatro ou mais episódios ao ano (EGAN e LIPSKY 2000, DAVIES e PATRUNO 2000).

De acordo com EGAN e LIPSKY (2000), são raras as complicações decorrentes à candidíase vulvovaginal, as quais se correlacionam à corioamnionite, gestação e à vestibulite vulvar.

Os fatores de predisposição a episódios dessa vulvovaginite são de natureza endógena e exógena. LARSEN e MONIF (2001) descrevem a estreita ligação das infecções com variações estrogênicas, com a quantidade de glicogênio disponível na cavidade vagina e com a quantidade de lactobacilos presentes.

Outros autores (ROSSI e col. 2000, HALBE 2000) acrescentam deficiências do sistema imunológico e presença de reservatórios extragenitais de fungos, como orofaringe e trato intestinal. Assim, as infecçōes por fatores internos ocorrem com maior freqüência: na gravidez; em casos de diabetes mellitus descompensado; com o uso de contraceptivos orais de alta dosagem, antibióticos de amplo espectro e medicamentos imunossupressores; ou ainda, com agravos que deprimem o sistema imune, como na infecção pelo HIV.

Quanto aos fatores exógenos, verifica-se o aumento da doença pelo contato com substâncias alérgenas e/ou irritantes; em mulheres com hábitos de higiene ou vestuário inadequados ou obesas, pelo fato de não favorecerem a ventilação, propiciando o aumento da umidade junto ao intróito vaginal, facilitando, desse modo a proliferação fúngica (FERNÁNDEZ e LOMBARDIA 2002). 
Dentre as vulvovaginites associadas ao gênero Candida, a espécie mais prevalente é a representada pela C. albicans, com $90 \%$ dos casos. Outras espécies chamadas não-albicans, tais como: $C$. tropicalis, $C$. glabrata, C. krusei, C. parapsilosis podem levar a quadros clínicos semelhantes e são responsáveis por aproximadamente $20 \%$ do total de casos (DAVIES e PATRUNO 2000). Essas espécies tendem ser mais prevalentes nos casos crônicos, como também apresentar resistência aos tratamentos habituais, e $33 \%$ dos casos de recorrência das infecções são atribuidos a C. glabrata, C. parapsilosis e Saccharomyces cerevisiae (NYIRJESY 2001).

Por outro lado, CHECA e SÁNCHEZ (2001) reportam que a candidiase vulvovaginal não é considerada uma DST, visto que pode ser componente da flora endógena em até $50 \%$ das mulheres em idade fértil, porém não se exclui a contaminação por essa via, uma vez que alguns estudos demonstram a interrelação da infecção com o início da atividade sexual, mas sem evidenciar associação com o número de parceiros e freqüência do coito.

Os sinais e sintomas dependem do grau de infecção, podendo se apresentar isolados ou associados, sendo que a principal queixa é o prurido vulvovaginal, muitas vezes acompanhado de ardor ou dor na micção e dispareunia. O corrimento é geralmente branco, grumoso, inodoro e com aspecto caseoso de "leite coalhado". A inspeção clínica pode revelar hiperemia; edema vulvar; fissuras e maceração da vulva e pele; vagina e colo recobertos por placas brancas ou branco-acinzentadas aderidas à mucosa. Os sintomas são exacerbados na semana que antecede a menstruação, trazendo alívio após o início do sangramento menstrual. (NYIRJESY 2001, EGAN e LIPSKY 2000).

Candida é um fungo dimorfo que pode ser encontrado na forma unicelular, como blastosporos, e filamentar, como pseudo-hifas. Os 
blastosporos constituem a forma resistente do fungo e estariam associados com as colonizações assintomáticas. Por outro lado, as hifas ou micélios são as formas germinativas, tendo capacidade de invadir os tecidos e ocasionar a sintomatología própria da infecção (HALBE 2000).

A patogênese da candidiase envolve processos de adesão celular, e a habilidade de adesão de $C$. albicans, é superior à de outras espécies o que poderia explicar a maior freqüência de candidíase, causadas pela espécie albicans (ZIARRUSTA 2002).

A adesão ocorre pela união de uma proteína transmembrana da membrana micótica (análoga à integrina), a um receptor de membrana (iCb3 e fibronectina) da célula epitelial. Existem fatores, que podem atuar como promotores ou facilitadores do processo de adesão. Assim, um ambiente hiperestrogénico incrementa a exposição dos complexos epiteliais glicoproteicos, que atuam como receptores, facilitando a adesão dos fungos à superficie epitelial, enquanto situações de hipoestronismo, como prémenarca e menopausa, têm efeito contrário. Por outro lado, a flora lactobacilar representa um fator de proteção para essas infecções, pois compete, com o fungo, pelos receptores de membrana responsáveis pela adesão celular (HALBE 2000, ZIARRUSTA 2002).

Os mesmos autores revelam que 0 desencadeamento do processo inflamatório ocorre quando as pseudo-hifas invadem as células epiteliais, quebrando proteínas e causando danos à sua estrutura devido à produção de toxina ou protease celulares.

O diagnóstico laboratorial pode ser realizado por exame direto "a fresco" do conteúdo vaginal, que revela a presença de pseudo-hifas birrefrigentes e/ou de pequenas formações leveduriformes arredondadas e birrefringentes, denominadas blastosporos. No caso de $C$. glabrata, não há 
formação de pseudo-hifas in vivo, portanto, no exame "direto a fresco" são observados apenas blastosporos (DAVIES e PATRUNO 2000).

A visualização dos fungos é facilitada, adicionando-se $\mathrm{KOH}$ a $10 \%$ à lâmina a ser examinada e o pH é ácido, situando-se abaixo de 4,5 (MINISTÉRIO DA SAUDE 1999).

Outros métodos de coloração, como Papanicolaou, Gram, Giemsa, Azul de Cresil, também podem ser empregados em esfregaços do conteúdo vaginal, onde são visualisadas leveduras e/ou pseudo-hifas coradas, de acordo com a técnica empregada. Porém, o simples achado de leveduras na citologia oncótica em uma paciente assintomática não permite o diagnóstico de infecção clínica devido à sua baixa sensibilidade e, eventualmente ser, apenas representante da microbiota normal, razões pelas quais, não se justifica o tratamento (POWER 1998, ROSSI e col. 2000).

As culturas são realizadas em meios especificos como Sabouraud ou Nickerson, e devem ser restritas aos casos nos quais a sintomatologia é muito sugestiva e todos os exames anteriores sejam negativos, ou ainda, nos casos recorrentes, para identificar a espécie ou para a realização do teste de sensibilidade a antifúngicos (ROSSI e col. 2000).

O esquema terapêutico recomendado pelo MINISTÉRIO DA SAÚDE (1999) é realizado com diferentes apresentações dos fármacos: miconazol, tioconazol, isoconazol, terconazol, clotrimazol e nistatina, nas formas orais ou em aplicações tópicas de cremes ou óvulos. O tratamento sistêmico com itraconazol, fluconazol ou cetoconazol deve ser feito somente nos casos recorrentes ou de difícil controle, e, nestes casos, deve-se investigar causas sistêmicas predisponentes. Para alívio do prurido deve ser prescrito, quando necessário, embrocação vaginal, com violeta de genciana a $2 \%$. 


\subsubsection{Tricomoniase vaginal}

É uma DST causada pelo protozoário flagelado Trichomonas vaginalis, tendo como reservatório a cérvice uterina, a vagina e a uretra, podendo levar a um quadro de cervicocolpite.

De acordo com a OMS (WHO 2001b), a incidência mundial é a de aproximadamente 170 milhões de casos ao ano, com taxas decrescentes em países industrializados.

No Brasil, a UNAIDS/WHO (2002) refere incidência global de $2,32 \%$ na população, e ADAD e col. (2001), em estudo retrospectivo de quatro décadas, quando foi analisada a freqüência de $T$. vaginalis em secreções vaginais pelo teste de Papanicolaou, revelam que houve diminuição significativa desse protozoário, afirmando que a freqüência, em 1968 era de $17,3 \%$, passando, em 1998 , a menos de $3,4 \%$.

No entanto, em outros trabalhos, verifica-se incidência variável, de acordo com a população estudada. Assim, WIESE e col. (2000) em estudo meta-analítico de diagnósticos de tricomoníase vaginal obtidos através do exame direto "a fresco" e Papanicolaou, reportam prevalências de 2 a $26 \%$.

Mais da metade das mulheres portadoras de tricomoníase vaginal são completamente assintomáticas, e os protozoários são encontrados em mais de $50 \%$ dos parceiros sexuais de mulheres infectadas (MINISTÉRIO DA SAÚDE 1999).

As principais consequêencias clínicas associadas à tricomoniase são relacionadas a complicações perinatais como ruptura prematura de membranas, parto pré-termo e em recém nascidos de baixo peso (WHO 2001b). 
A tricomoníase é considerada fator de risco para outras DST e, mais recentemente, estudos revelaram que mulheres infectadas pelo protozoário têm risco duas vezes maior de contaminação pelo vírus HIV, devido a erosões da mucosa, comuns nos quadros de tricomoniase, que facilitam a penetração do vírus HIV (WHO 2001b, WIESE e col. 2000, CHECA e SÁNCHEZ 2001).

Por outro lado, os fatores de risco associados à ocorrência do quadro de tricomoniase são: múltiplos parceiros sexuais, raça negra, infecções virais por HPV, HSV e gonorréia coexistentes, abstinência de contraceptivos hormonais ou de métodos de barreira. Apesar da transmissão sexual ser a mais freqüente, outras formas de contágio menos freqüentes são consideradas, como o uso de toalhas molhadas, assentos sanitários, piscinas, contato indireto com urina, secreção vaginal ou sêmem contaminados (ROSSI e col. 2000).

As queixas clínicas mais freqüentes são disúria, dispareunia, polaciúria e dor abaixo do ventre, ocorrendo piora do quadro, após a menstruação ou relação sexual. $O$ exame ginecológico mostra hiperemia vulvar, vaginal e do colo uterino, que pode apresentar colpite focal e teste de "Schiller" positivo, em significativo número de pacientes. Acompanha freqüentemente um profuso corrimento vaginal amarelo-esverdeado, bolhoso e fétido (HALBE 2000, DAVIES e PATRUNO 2000).

O protozoário Trichomonas vaginalis apresenta quatro flagelos e uma membrana ondulante ântero-lateral, responsáveis pela grande mobilidade. O tempo de incubação da doença é de dois a oito dias, podendo o protozoário permanecer vivo no meio exterior durante seis horas e em água clorada de piscina, por 15 minutos (HALBE 2000).

O exame "a fresco" do conteúdo vaginal, com uma gota de soro fisiológico em microscópio comum, identifica o agente com facilidade, 
devido à sua grande motilidade. Em geral, são duas a três vezes maiores do que os leucócitos que são abundantes nesse quadro (FERNÁNDEZ e LOMBARDIA 2002, CHECA E SÁNCHEZ 2001).

Freqüentemente, também o método de Papanicolaou é empregado no diagnóstico de tricomoníase, embora sua sensibilidade seja questionada (AVILÉS e col. 2001). Já WIESE e col. (2000) ressaltam que, em populações com alta prevalência, o Papanicolaou tem boa sensibilidade.

O quadro citológico observado na tricomoníase, empregando o método de Papanicolaou, é de uma grande quantidade de leucócitos e histiócitos, em meio a células epiteliais, as quais evidenciam hipercromasia, pseudo-eosinofilia, vacúolos citoplasmáticos, halos perinucleares. 0 protozoário apresenta-se como um organismo unicelular ovóide, corado palidamente, mostrando granulaçōes eosinófilas no citoplasma e um núcleo central ou excêntrico vesiculoso e alongado (TAKAHASHI 1982, POWERS 1998, ADAD e col. 2001).

Outros métodos de coloração, como Gram e Giemsa, também são utilizados, principalmente em locais de poucos recursos, e mostram sensibilidade semelhante ao exame "a fresco", porém a especificidade é bem inferior. A cultura está indicada nos casos repetitivos, em que não se encontra $\mathrm{o}$ agente no exame microscópico e o pH vaginal situa-se entre 5,0 e 5,5 (DAVIES e PATRUNO 2000, EGAM e LIPSKY 2000).

O tratamento deve incluir o parceiro, e as drogas de eleição são os derivados imidazólicos em dose única ou fracionada, associados a cremes à base de metronidazol ou clotrimazol para alivio da sintomatologia (ROSSI e col. 2000). 


\subsubsection{Cervicites}

Conceitua-se cervicite ou endocervicite como a inflamação da mucosa endocervical ou, mais especificamente, do epitélio colunar do colo e de suas glândulas, acompanhado geralmente de corrimento patológico do canal endocervical (HALBE 2000).

Dentre os agentes causais associados à etiologia da cervicite, destacam-se, por sua importância clínico-epidemiológica: Neisseria gonorrhoeae e Chlamydia trachomatis. Outras bactérias, além de vírus como - HSV e HPV e patógenos da própria flora cérvico-vaginal, também são relacionados (AIDSCAP 1998, ONUSIDA 1998).

Na maioria das mulheres, as infecções por Chlamydia tracomatis e a gonorréia seguem curso assintomático. No entanto, podem causar sérias complicações, tais como infertilidade, doença inflamatória pélvica, gravidez tubária. Esse quadro associa-se, por sua vez, à possivel infecção de seus conceptos, causando-lhes pneumonia ou cegueira (SEADI e col. 2202, ONUSIDA 1998).

Essas infecções são passiveis de cura com tratamentos antimicrobianos; daí depreende-se a grande repercussão social que tais agravos podem causar. Segundo a OMS (WHO 2001b), a prevalência de Chlamydia em mulheres jovens pode chegar a $27 \%$. No Brasil, AMARAL (1998) reporta uma prevalência de $16 \%$ em estudos realizados em clínicas de planejamento familiar e de pré-natal.

As taxas de gonorréia são flutuantes ao redor do mundo variando de 5 a 17\%, tendo prevalência elevada em países africanos (WHO 2001b). Em nosso meio, alguns estudos mostram prevalência de $8 \%$ (AMARAL 1998). 
$\mathrm{Na}$ cervicite causada por ambos os agentes, alguns sintomas genitais leves, como corrimento vaginal, dispareunia ou disúria, podem ocorrer. O colo uterino fica habitualmente edemaciado, sangrando facilmente ao toque da espátula; às vezes, pode ser verificada a presença de mucopus no orifício externo do colo, caracterizando um quadro de cervicite mucupurulenta (MINISTÉRIO DA SAÚDE 1999).

A bactéria N. gonorrhoeae é um diplococo Gram-negativo anaeróbio facultativo, e a Chlamydia trachomatis é um organismo intracelular obrigatório. Os sorotipos $D, E, F, G, H, I, J$ e $K$ são responsáveis pela infecção da endocérvice de $C$. trachomatis, que é uma bactéria imóvel, com ciclo de desenvolvimento bifásico e replicação dentro de vacúolos na célula hospedeira, formando inclusões citoplasmáticas características. A replicação apresenta um ciclo multimórfico e sem sincronismo de desenvolvimento, ocorrendo duas formas bem distintas: os corpos elementares e os corpos reticulares (SEADI e col. 2002, HALBE 2000).

O método ideal para o diagnóstico de $N$. gonorrhoeae é a cultura do gonococo em meio seletivo de Thayer-Martin, a partir de amostras endocervicais, pois a coloração pelo método de Gram tem sensibilidade limitada da ordem de apenas $30 \%$. O diagnóstico definitivo da cervicite causada por Chlamydia trachomatis é feito pela cultura, uma técnica altamente sofisticada, e por meio de testes que empregam imunufluorescência direta, enzimaimunoensaios ou técnicas de amplificação de DNA (SEADI e col. 2002, WHO 1999a).

Nas últimas décadas, vários ensaios vêm descrevendo critérios para demonstrar o envolvimento dessas bactérias na cervicite mucopurulenta. Assim, KIVIAT e col. (1985), empregando o método de Papanicolaou, descreveram critérios, alcançando $95 \%$ de sensibilidade e $50 \%$ de valor preditivo positivo no diagnóstico de infecções por Chlamydia trachomatis. Outros autores, como Brunhamm, citado por FERNÁNDEZ E 
LOMBARDIA (2001), descreveram critérios de contagem de leucócitos, em esfregaços corados pelo método de Gram para o diagnóstico presuntivo dessas cervicites (SELLORS e col. 1998).

O tratamento recomendado envolve os dois agentes bacterianos, tendo em vista as dificuldades de se obter um diagnóstico preciso, sendo que as drogas de eleição, administradas via oral, são: azitromicina ou oxiciclina ou eritromicina associada a uma das seguintes drogas: ofloxacina, ciprofloxacina, cefixima, ceftriaxona ou tianfenicol.

\subsection{ABORDAGEM SINDRÔMICA}

Diante das dificuldades encontradas para a realização de diagnósticos etiológicos de diversas DST, a OMS, a partir de 1990, propõe o manejo sindrômico para os pacientes sintomáticos que procuram os centros de atenção primária de saúde. As características principais da abordagem sindrômica de casos baseiam-se na classificação dos principais agentes patógenos causais, por meio de síndromes clínicas produzidas pelos mesmos; utilização de diagramas ou polígonos de decisão derivados dessa classificação, para abordar uma sindrome especifica; tratamento de todas as causas importantes da síndrome; notificação e tratamento dos parceiros sexuais; emprego, desde que possível, de procedimentos de laboratório simples e baratos; e ações educativas e de aconselhamento (WHO 2001a; MINISTÉRIO SAÚDE 1999).

Posteriormente, foi acrescida a avaliação de risco, a fim de implementar a acurácia da abordagem sindrômica, principalmente no caso dos corrimentos elou dor pélvica, objetivando associar fatores comportamentais e sócioculturais da paciente, que poderiam estar correlacionados às DST. Esses fatores foram mensurados e pontuados por um sistema de escore com validade apenas local, uma vez que implicam 
situações demográficas e de comportamento específicas (ONUSIDA 1998; MAYAUAD e col. 1998).

A introdução da avaliação de risco foi incorporada, para sanar a limitação dessa metodologia focada apenas nos aspectos clínicos, principalmente nos locais de baixa prevalência de DST, porém com alta freqüência de corrimentos, associados à vaginites endógenas, principalmente em mulheres jovens. Assim, poderia ocorrer tratamento desnecessário devido a diagnósticos incorretos de infecções gonocócicas ou por C. trachomatis e, por outro lado, muitas pacientes deixariam de ser tratadas pois, na maioria das vezes, esses casos são assintomáticos.

Desta forma, parece de consenso na comunidade científica que o maior entrave no emprego do manejo sindrômico é no que se refere ao diagnóstico e tratamentos corretos da gonorréia e das infecçōes por $C$. trachomatis em mulheres. Assim, vários algoritmos foram testados e adaptados às realidades locais, direcionados principalmente ao manejo sindrômico das DST em mulheres (HAWKES e col. 1999, FONCK e col. 2000).

AMARAL (1998) descreve que o manejo sindrômico foi testado em diversos países, como Tanzânia, resultando em redução da incidência em $42,0 \%$ dos casos de infecção por HIV, num período de dois anos a partir da intervenção. Outros estudos também evidenciam redução significativa de outras DST, como úlceras genitais e tricomoníase (AIDSCAP 1998; ONUSIDA 1998, DALLABETA e col. 1998).

No Brasil, o trabalho multicêntrico realizado por MOHERDAUI e col. (1998) foi reconhecido e validou essa proposta. O Ministério da Saúde passou a reforçar a adoção da abordagem sindrômica e a estimular a realização da notificação das DST, para o controle epidemiológico desses agravos. 
A definição de casos para o manejo sindrômico em mulheres com queixa clinica de corrimento, de acordo com o MINISTÉRIO DA SAÚDE (1999), ficou caracterizada como: síndrome do corrimento cervical, quando há presença de mucupus cervical, verificado obrigatoriamente durante o exame especular, associada etiologicamente à gonorréia e cervicite por Chlamydia trachomatis; e síndrome do corrimento vaginal, quando há presença de corrimento vaginal associado à hiperemia, elou edema da mucosa vaginal, associado ou não a sinais de colpite, com ou sem ectrópio e etiologicamente vinculada à tricomoníase, candidiase e vaginose bacterina.

Mesmo na ausência dos sinais clínicos para cervicite, a paciente é considerada portadora assintomática $e$ deve receber 0 tratamento concomitante para gonorréia e clamídia, quando tiver a atribuição de um escore igual ou maior que dois, de acordo com os critérios de risco previamente estabelecidos, conforme descritos no anexo 1.

Devido às dificuldades e limitações encontradas desde a implantação da Vigilância Aprimorada de DST, recentemente foi proposto um sistema simplificado de notificação de DST, que utiliza o Sistema de Informações de Agravos de Notificação (SINAM), para notificar três síndromes e três doenças específicas, consideradas estratégicas do ponto de vista epidemiológico, na tentativa do melhor controle das DST, sendo que a síndrome do corrimento cervical é integrante desse sistema (MINISTÉRIO DA SAÚDE 1998b 1999 2000).

No entanto, não existe ainda um impacto significativo dessa intervenção em nosso país, visto que, segundo dados publicados no Boletim Epidemiológico de DST (MINISTÉRIO DA SAÚDE, 1998a), os mais freqüentes casos de DST diagnosticados etiologicamente em maiores de 12 anos e notificados no período de março de 1997 a junho de 1998 faziam parte de um universo amostral de apenas 4.824 casos, dentre os quais a 
vaginose, a infecção por HPV e a tricomoniase foram as DST mais freqũentes.

O Grupo de Epidemiologia do Programa Estadual de DSTIAIDS (PEDST/AIDS-SP) de São Paulo compilou 10.575 de casos, notificados no período de 1987 a novembro de 1997, nos quais as vulvovaginites, chegam a representar $68,6 \%$ de todos aqueles notificados, decorrentes principalmente da demanda nos ambulatórios de ginecologia, deixando claro, que tais dados não refletem a realidade estadual (SECRETARIA DE ESTADO DA SAÚDE 1998).

Em relação ao diagnóstico e tratamento de DST em mulheres no Brasil, o que se constata é que, na rotina dos ambulatórios de ginecologia, as queixas de corrimento representam o maior contingente de consultas (EGAN e LIPSKY 2000, HALBE 2000, ROSSI e col. 2000), e que, historicamente há uma maior demanda espontânea e aceitabilidade desses serviços e também dos serviços de prevenção de câncer de colo. Dessa forma, o clínico, por sua vez, utiliza o protocolo de resultados do teste de Papanicolaou, que sugere presuntivamente o diagnóstico da maioria das DST para instituir o tratamento (AMARAL 1998).

Verifica-se, assim, que a irregularidade de informações nos prontuários das pacientes associada à falta de integralização dos Programas de Prevenção de Câncer do Colo Uterino e DSTIAIDS, pode levar à realização de exames repetitivos e desnecessários de Papanicolaou, com possiveis sub ou sobretratamentos dos quadros de corrimento. Por outro lado, o serviço de prevenção é importante porta de entrada de pacientes potencialmente portadoras de DST, pois, na prática diária, constata-se que a maioria esmagadora de mulheres procura o serviço quando estão apresentando algum sintoma da área genital, principalmente, corrimento. 
Por outro lado, há várias decádas a sensibilidade desse método vem sendo testada para o diagnóstico de DST, com uma variabilidade muito grande nos resultados que possam garantir sua eficiência e, por essa razão, alguns autores não recomendam seu emprego para esse fim, devido à baixa sensibilidade. Outros admitem sua utilização, geralmente associada à clínica, para o diagnóstico de vaginoses, tricomoníase e alterações citopáticas causadas por HPV e HSV (AVILÉS e col. 2001, HALBE 2000, PLATZ-CHRISTENSEN e col. 1995, PERLMAN e col. 1998, POWERS 1998, ROSSI e col. 2000, WIESE e col 2000).

Ocorre ainda que alguns estudos apontam uma certa resistência por parte do clínico em tratar o paciente sem um diagnóstico laboratorial de apoio, visto que é tradicional no seu aprendizado da graduação, a recomendação de que, para exercer a boa medicina, há necessidade de se indicar a realização de diagnósticos laboratoriais, antes da prescrição do medicamento, o que, de certa forma, impõe certo prestígio frente ao paciente (AIDSCAP 2000; DADIAN 1996, MOHERDAUI 1998).

Assim, inferimos que o clínico, não vendo outro recurso para o diagnóstico, colhe material para realização do teste preventivo, em vez de aplicar o sistema de abordagem sindrômica, que parece ser uma ferramenta simples de tratamento das DST e permite potencialmente, prevenir contra doenças muito mais graves, como, por exemplo, a infecção pelo vírus HIV.

Tendo como fundamento, os dados da literatura até agora descorridos, verifica-se que:

- a tendência atual da AIDS no Brasil é caracterizada pela feminização, pauperização, heterossexualização e interiorização em cidades de médio e pequeno porte, e que ações voltadas para as DST no país, direcionadas às populações femininas, que, sem dúvida nenhuma, se 
encontram em maior situação de risco e vulnerabilidade, não têm sido contempladas;

- na prática, há nítida verticalização das ações, dentro do próprio programa "DST"IAIDS, onde grandes investimentos são direcionados ao controle, prevenção e tratamento da AIDS em detrimento às DST, cuja transcendência foi claramente pontuada;

- mesmo o corrimento sendo o motivo mais freqüente de consultas em ginecologia, pouco se conhece sobre a prevalência das DST associadas a esse quadro, visto que os dados obtidos pela da Vigilância Epidemiológica, ainda são escassos e irregulares, não permitindo extrapolar tendências desses agravos para ações de controle;

- a abordagem sindrômica, ainda pouco praticada em nosso meio, deve ser estimulada, pois trata-se de uma metodologia simples, e barata, que propicia o controle e tratamento nos serviços de atenção primária da saúde, sem a necessidade de métodos laboratoriais sofisticados para 0 diagnóstico, desde que se conheça a prevalência das principais DST e os fatores de risco associados em determinada localidade.

Dessa forma, essas premissas foram norteadoras da definição dos objetivos deste projeto. 


\section{OBJETIVOS}

\subsection{PRINCIPAL}

Avaliar o emprego da abordagem sindrômica para diagnóstico e tratamento de DST em mulheres que procuram os ambulatórios de ginecologia da rede pública da cidade de Tremembé, com queixa clínica de corrimento e/ ou para realização do teste preventivo de Papanicolaou.

\subsection{ESPECÍFICOS}

Conhecer a prevalência dos principais agentes etiológicos associados à presença de corrimento cérvico-vaginal, tais como: vaginose bacteriana, candidiase, tricomoníase, gonorréia e infecções por Chlamydia tracomatis;

Conhecer os principais fatores de risco sociocomportamentais de mulheres de Tremembé relacionados, às DST em estudo;

Comparar a sensibilidade, especificidade e valor preditivo positivo do fluxograma proposto pelo Ministério da Saúde (anexo 1) para o manejo de corrimento, frente ao diagnóstico clínico e dos resultados microbiológicos obtidos no teste de Gram e de Papanicolaou;

Testar a sensibilidade de critérios diagnósticos já descritos na literatura, empregando-se métodos laboratoriais simples e baratos como o de Gram e de Papanicolaou, que possam vir a contribuir para o diagnóstico presuntivo de cervicites por Chlamydia trachomatis, associando-os com alguns fatores de risco identificados no estudo;

Adaptar o algoritmo para a realidade local. 


\section{METODOLOGIA}

O estudo foi realizado no município de Tremembé-SP que tem cerca de $85 \%$ da população distribuída em área urbana. A população feminina é representada por 18.916 habitantes, com maiores percentuais nas faixas etárias de 10 a 34 anos. $O$ atendimento em gineco-obstetrícia é realizado por quatro médicos, em regime de 20 horas semanais e com demanda de quatro consultas/hora.

O médico que aceitou participar da pesquisa era lotado no único Centro de Saúde do município e foi treinado previamente para obtenção das coletas específicas, e para o preenchimento do protocolo clínico de anamnese.

\subsection{AVALIAÇÃO DO PILOTO}

Inicialmente, foram convidadas a participar da pesquisa inicialmente, cinco pacientes para realização do pré-teste com os questionários padronizados (anexo 3 ), visando verificar a clareza e compreensão dos itens. Dessa mulheres, que assinaram o consentimento informado (anexo 2), foi coletado material para avaliar itens de procedimento técnico e de fluxo.

\subsection{AMOSTRA}

O cálculo da amostra foi obtido, tendo como base uma população finita de 15.792 mulheres de 10 anos ou mais, residentes no município em 2000, segundo dados do MINISTÉRIO DA SAÚDE (2002a). O tamanho da 
amostra foi calculado para uma prevalência de $3 \%$ de DST, nível de confiança de $95 \%$ e margem de erro de 3,3\%, resultando em 102 mulheres.

Assim, participaram do estudo 105 mulheres que procuraram o Centro de Saúde de Tremembé de agosto a outubro de 2002, com queixa clínica de corrimento e/ou para realização do teste preventivo de Papanicolaou.

\subsubsection{Critérios de inclusão}

Todas as mulheres que aceitaram participar da pesquisa, conforme o termo de consentimento informado, que atente às exigências da resolução 196/96 do Ministério da Saúde (anexo 2), com idade a partir de 12 anos;

Mulheres com fluxo vaginal e ou prurido; desconforto ou dor no baixo ventre; mulheres com ou sem queixa, que procuraram o serviço de saúde para exame preventivo de Papanicolaou; mulheres sem tratamento prévio nos 30 dias que antecederam a consulta.

\subsubsection{Critérios de exclusão}

Gestantes; mulheres em período menstrual; as que mantiveram relações sexuais nas 48 horas precedentes à consulta; aquelas que fizeram uso de duchas vaginais, ou aquelas que, na hora da inspeção clínica, não apresentavam secreção cérvico-vaginal suficiente para a realização dos testes. 


\subsection{COLETA DE DADOS}

\subsubsection{Dados demográficos e história clínica}

Cada paciente foi argüida antes da consulta, pela autora do estudo, com relação a dados demográficos, histórico gineco-obstétrico e comportamentais.

As respostas informadas pelas pacientes foram assinaladas seguindo-se o protocolo padronizado (anexo 3 ).

\subsubsection{Exame clínico ginecológico}

Foi realizado o exame da genitália externa e da região anal, seguido da introdução do espéculo sem lubrificação, para observar a vagina, suas paredes, fundo de saco e colo uterino. Na presença de corrimento, a quantidade $e$ as características físicas do mesmo foram anotadas no protocolo (anexo 3).

\subsubsection{Coleta de esfregaço cérvico-vaginal}

A coleta de material para o teste de Papanicolaou foi realizada com espátula de Ayre na região ectocervical e no fundo posterior da vagina que foi distendido na lâmina, sempre ocupando a primeira metade do leito laminar, após a extremidade fosca. Com escova endocervical, coletou-se material da endocérvice que foi distendido na porção distal da lâmina e todo o esfregaço foi imediatamente fixado com carbovax.

Os esfregaços foram encaminhados ao "Laboratório do Vale Taubaté" para serem processados, conforme recomendado pelo programa de prevenção de câncer do colo uterino (INCA 2002). 


\subsubsection{Coleta de material para pesquisas microbiológicas}

Os procedimentos técnicos a seguir foram descritos de acordo com aqueles rotineiramente, utilizados em laboratórios de saúde pública e em manuais da OMS (WHO 1999a).

Do canal endocervical, foram realizadas duas tomadas de material na seguinte ordem:

a) Para pesquisa de Chlamydia trachomatis, foi introduzido um swab alginatado específico para coleta endocervical (CB-Labcenter), o qual foi rotacionado por aproximadamente 5 segundos, e impresso por decalque, no espaço delimitado de uma lâmina especifica (Perfecta-marcada para Clamídia). A lâmina foi acondicionada numa caixa plástica para transporte à temperatura ambiente.

Com o mesmo swab, foi confeccionado um outro esfregaço para realização da coloração de Gram.

b) Para cultura de N. gonorrhoea, foi introduzido o swab que acompanha o meio de transporte Stuart (CB-Labcenter), rotacionando-o por aproximadamente 5 segundos e acondicionando-o no tubo com meio de transporte.

Da parede posterior da vagina e fundo de saco vaginal foi coletado material com um swab estéril e seco, com o qual se confeccionou, primeiramente, um esfregaço em lâmina para coloração de Gram, e logo a seguir, foi introduzido num tubo de ensaio, contendo $1 \mathrm{ml}$ de solução salina que foi mantido em temperatura ambiente, destinado à cultura de Candida sp e exame direto "a fresco", para pesquisa de vaginose bacteriana, leveduras em brotamento ou pseudo-hifas e Trichomonas vaginalis. 


\subsubsection{Testes realizados durante a consulta}

a) Após todas as coletas, o clínico procedeu ao teste de pH com fita de escala colorimétrica (Merck), encostando a mesma na parede vaginal por 1 minuto.

Valores normais do $\mathrm{pH}$ vaginal situam-se entre 4 a 4,5. Assim, valores menores que 4 sugerem a presença de candidiase e valores acima de 4,5 sugerem tricomoniase e/ou vaginose bacteriana.

b) $O$ teste de "Schiller" (solução de lugol 10\%) foi aplicado para evidenciar lesões do colo e ectopias. Áreas iodo-claras indicam um teste positivo, podendo sugerir cervicite.

c) Após a retirada do espéculo, aproveitou-se o próprio instrumento, na região de maior concentração dos restos de secreção para realização do teste de "Whiff", que resulta na emanação de cheiro de "peixe podre" ao se gotejar uma gota de solução de $\mathrm{KOH}$ a $10 \%$ sobre o fluido vaginal. Nesse caso, considera-se positivo, fornecendo o diagnóstico sugestivo de vaginose bacteriana e, em alguns casos, da tricomoníase.

d) Foi realizado o exame de toque vaginal, observando-se se há dor à mobilização do colo e/ou anexos.

A medida de $\mathrm{pH}$, o teste de "Whiff", os aspectos clínicos do colo uterino e características do corrimento foram anotados no protocolo padronizado (anexo 3). 


\subsection{UTILIZAÇÃO DO ALGORITMO PARA CORRIMENTOS VAGINAIS, PROPOSTO PELO MINISTÉRIO DA SAÚDE}

Ao final do exame clínico e tendo definido o escore de risco da paciente, segundo o algoritmo proposto (anexo 1), foi emitido o diagnóstico, associando-se o valor de $\mathrm{pH}$ e o teste de "Whiff". O clínico anotou os resultados no protocolo da pesquisa, e o tratamento foi instituído, tanto para a paciente como para o parceiro, quando necessário. Procedeu-se a aconselhamento e encaminhou-se a paciente para o retorno.

\subsection{ENCAMINHAMENTO DO MATERIAL AO LABORATÓRIO}

Todos os materiais coletados, devidamente identificados, foram encaminhados ao Setor de Bacteriologia do Laboratório I de Taubaté, no mesmo dia, com os devidos cuidados de biossegurança e não ultrapassando 4 horas após a coleta. Nesse laboratório foram realizadas as análises microbiológicas.

\subsection{PROCEDIMENTOS LABORATORIAIS}

\subsubsection{Pesquisa de Chlamydia trachomatis}

A lâmina foi fixada em metanol por 5 minutos e mantida em freezer a $-20^{\circ} \mathrm{C}$. 
As lâminas foram encaminhadas semanalmente ao Laboratório Oswaldo Cruz de Taubaté, para a realização dos testes de imunofluorescência direta, onde foi avaliada a presença de corpúsculos elementares em microscópio de fluorescência com epi-iluminação, seguindo os procedimentos e a interpretação dos resultados em relação ao número de células epiteliais e corpúsculos elementares presentes no esfregaço, conforme recomendados pelo fabricante do kit (Chlamydia Direct IF bioMérieux)

Foram consideradas positivas, as lâminas com 10 ou mais corpúsculos elementares fluorescentes por campo microscópico de $400 \mathrm{X}$ e com, no mínimo, cinco células epiteliais presentes no campo demarcado da lâmina (MELLES e col. 2000).

\subsubsection{Cultura de Neisseria gonorrhoea}

O material foi inoculado em meio seletivo de Thayer-Martin modificado e incubado em atmosfera de 5 a $10 \%$ de $\mathrm{CO}_{2}$, usando-se o método da "jarra com vela" a $35^{\circ} \mathrm{C}$ por $24-48$ horas. A identificação presuntiva é determinada pela morfologia das colônias; características tintoriais de diplococos Gram-negativos e pela reação de oxidase positiva.

\subsubsection{Cultura e identificação de leveduras}

Retirou-se um inóculo, com alça, da secreção acondicionada em salina e semeou-se em agar-Sabouraud dextrose, em tubos acrescidos de cloranfenicol, que foram incubados à $30^{\circ} \mathrm{C}$ por um periodo de até 15 dias (SILVA e col. 1997).

As colônias morfologicamente distintas, foram repicadas em agarSabouraud dextrose em placas e incubadas à $30^{\circ} \mathrm{C}$, por 48 horas. 
A partir das colônias isoladas neste meio, foi realizada a identificação de $C$. albicans, empregando-se:

\subsubsection{Técnica do tubo germinativo}

As colônias foram repicadas em soro humano e incubadas a $36^{\circ} \mathrm{C}$, por três horas. Durante o período de incubação, ou seja, entre duas horas e meia a três horas, uma gota de soro foi depositada entre lâmina e lamínula e observada ao microscópio, com aumento de 400X, para pesquisa de formação de tubo germinativo.

\subsubsection{Pesquisa de clamidósporo}

As colônias obtidas em isolamento do agar Sabouraud em placas, foram cultivadas em lâmina, usando-se agar-fubá com tween 80 , pesquisando-se, após 72 horas sob o microscópio: presença de filamentos com produção de hifas/pseudo-hifas características de Candida sp; formação de clamidósporos, característicos da espécie $C$. albicans; e eventualmente só presença de blastoconídios, indicando leveduras.

Não era escopo do trabalho, realizar a identificação de outras espécies do gênero Candida.

\subsubsection{Bacterioscopia}

\subsubsection{Exame direto "a fresco"}

Do tubo com salina contendo o material coletado com swab da parede vaginal, foi retirada de uma a duas gotas do sedimento que foi depositado em uma lâmina, coberto por lamínula, e imediatamente observado em microscópio de luz, sob aumento de 100 e $400 \mathrm{X}$. 


\subsubsection{Coloração de Gram}

As lâminas com esfregaço da endocérvice e do fundo de saco foram coradas pelo método de Gram modificado (SIQUEIRA e ALMEIDA 1990) e observadas ao microscópio de luz, com aumento de 400X e 1000X sob óleo de imersão.

\subsubsection{Teste de Papanicolaou}

Os esfregaços para o exame preventivo foram corados segundo as normas padronizadas pelo Programa de Prevenção de Câncer do Colo Uterino (INCA 2002) e avaliados por três citotécnicas participantes do estudo que desconheciam os resultados da avaliação clínica e microbiológica das pacientes.

A avaliação oncótica e microbiológica dos esfregaços seguiu os padrōes empregados nos laboratórios de citopatologia e os laudos foram emitidos num protocolo semelhante à requisição de exame citopatológico preconizada pelo Ministério da Saúde, acrescido de três itens específicos definidos pela autora (anexo 3).

\subsubsection{Parâmetros e critérios para a leitura do material}

A leitura de todas as lâminas e culturas realizadas no Setor de Bacteriologia e de Micologia do Instituto Adolfo Lutz de Taubaté, foram efetuadas pelos respectivos biologistas responsáveis de cada setor.

\subsubsection{Exame direto "a fresco"}

Foi considerado um resultado positivo ou negativo, quando visualizou-se ou não a motilidade de $T$. vaginalis; leveduras em brotamento 
elou pseudo-hifas sugestivas de Candida sp; mais de $20 \%$ de clue cells (células epiteliais recobertas por pequenas bactérias, conferindo aspecto granuloso com bordos celulares indistintos), indicadoras de vaginose bacteriana (NAVARRETE e col. 2000).

\subsubsection{Esfregaço endocervical corado pelo Gram}

Foi contado o número de polimorfonucleares encontrados em cinco campos microscópicos não-adjacentes, usando objetiva para aumento de 1000X, sob óleo de imersão (SELLORS e col. 2000).

Um resultado maior ou igual a 10 polimorfonucleares foi considerado como sugestivo de cervicite mucopurelenta.

Pesquisou-se a presença ou ausência de diplococos Gramnegativos intracelulares, sugestivos de gonorréia.

\subsubsection{Esfregaço de fundo de saco vaginal corado pelo Gram}

Com objetiva para aumento de 100 e 400X, foi considerado um resultado positivo o encontro de: blastoconídios; pseudo-hifas; $T$. vaginalis; clue cells.

Para o diagnóstico de vaginose bacteriana, foram empregados os critérios descritos por NUGENT e col., citados por EGAN e LIPSKY (2000), ROSSI e col. (2000) e NAVARRETE e col. (2000), ou seja, uma escala de escores de zero a 7 , como descrito no quadro 2 (anexo 4).

Assim, um escore variando de zero a 3, indicou flora normal; de 4 a 6, flora intermediária; e igual a 7 , vaginose bacteriana, considerando-se ainda a presença de mais de $20 \%$ das células epitelias recobertas por 
pequenos bacilos Gram-variáveis ou Gram-negativos e/ou pequenos bacilos Gram-negativos curvos.

\subsubsection{Esfregaço de Papanicolaou}

Os parâmetros adicionados à avaliação oncótica de rotina, foram analisados, observando-se 5 campos não adjacentes do esfregaço, na região onde foi depositada a coleta endocervical (identificada pela presença de muco cervical e células endocervicais), com aumento de $400 \mathrm{X}$ visando:

A) quantificar polimorfonucleares no seguinte sistema de escore (KIVIAT e col. 1985):

zero $=$ nenhum polimorfo

$1+=$ quando menos da metade de células presentes no campo microscópico, estiver obscurecida por leucócitos polimorfonucleares.

$2+$ = quando mais da metade de células presentes no campo microscópico, estiver obscurecida por leucócitos polimorfonucleares

B) presença ou ausência de células endocervicais reativas (isoladas, representadas por núcleos desnudos e aumentados).

C) presença ou ausência de células metaplásicas com vacúolos sem inclusões.

A indicação de cervicite foi dada pelo escore $2+$ associado a $B$ elou C. 


\subsection{PROCESSAMENTO E ANÁLISE DOS DADOS}

Os questionários foram digitados num banco de dados criado no programa Sphinx Léxica 2000. Tabelas de freqüências absolutas e percentuais foram montadas com o objetivo de descrever caracteristicas sociodemográficas, gineco-obstétricas e comportamentais das pacientes amostradas.

Para análises descritivas, foram calculadas as médias com respectivo desvio padrão. Testes de sensibilidade, especificidade e valor preditivo positivo, com intervalo de confiança de $95 \%$, foram calculados para avaliar o desempenho dos diagnósticos empregados.

Para a comparação de proporções entre variáveis de interesse, foi empregado o teste razão de odds (odds ratio), para tabelas $2 \times 2$ bivariada. Quando 0 software tornou-se limitado para a análise estatística, o banco de dados foi transferido para o software SAS (Statistical Analysis System) para tabelas com dupla entrada, estabelecendo-se o nível de significância em 0,05 . 


\section{RESULTADOS}

Das 109 mulheres que aceitaram participar da pesquisa, quatro foram excluídas por problemas na coleta dos materiais necessários para as análises laboratoriais. Portanto, de 105 pacientes participantes, obteve-se os dados demográficos, o histórico gineco-obstétrico e comportamental, bem como os resultados dos exames laboratoriais realizados nas secreções cérvico-vaginais. Esses dados, com as respectivas frequências, são descritos na série de tabelas de 1 a 17 e o fluxograma das pacientes, seguindo o modelo proposto pelo Ministério da Saúde para abordagem e tratamento dos corrimentos vaginais, é demonstrado na figura abaixo.

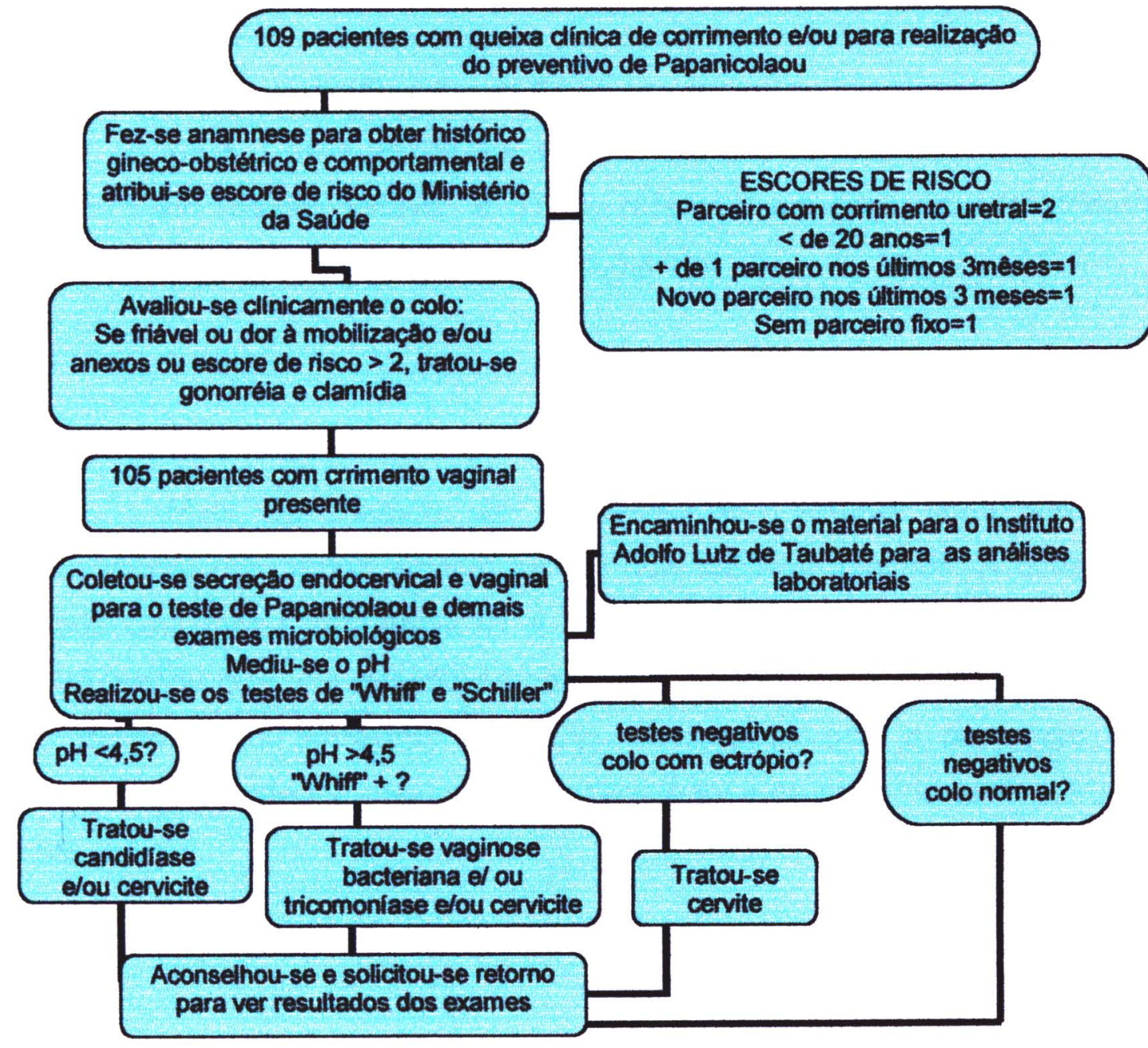

Figura 1. Fluxograma das 105 pacientes participantes do estudo. 


\subsection{CARACTERISTICAS SOCIODEMOGRÁFICAS}

Em relação às caracteristicas socioeconômicas e demográficas (tabela 1), verificou-se que a idade das pacientes estudadas situou-se entre 15 a 68 anos, com distribuição de $34,3 \%$ na faixa etária compreendida entre 25 a 34 anos. Cerca de $62,9 \%$ mulheres eram casadas ou viviam com parceiro em relação estável, e $37,1 \%$ referiram um grau de escolaridade equivalente ao $2^{\circ}$ grau completo ou incompleto.

Mais da metade da população em estudo tinha atividade remunerada com renda familiar de até dois salários mínimos. A ocupação citada com maior frequência foi a de empregada doméstica, faxineira ou babá, sendo que, em relação às pacientes que declararam terem parceiros no momento da entrevista $(n=99)$, verificou-se que a ocupação dos companheiros referida com maior freqüência foi a de operário da construção civil. 
Tabela 1. Características socioeconômicas e demográficas das mulheres que procuraram o Centro de Saúde de Tremembé, no período de setembro a novembro de 2002, com queixa clínica de corrimento e/ou para realização do preventivo de Papanicolaou. Tremembé, 2002.

\begin{tabular}{|c|c|c|}
\hline Caracteristicas & $n=105$ & $\%$ \\
\hline \multicolumn{3}{|l|}{ Distribuição por faixa etária } \\
\hline $15-24$ & 24 & 22,9 \\
\hline $25-34$ & 36 & 34,3 \\
\hline $35-44$ & 28 & 26,7 \\
\hline $45-54$ & 13 & 12,4 \\
\hline$\geq 55$ & 4 & 3,8 \\
\hline \multicolumn{3}{|l|}{ Estado marital } \\
\hline Solteira & 24 & 22,9 \\
\hline Casada & 57 & 54,3 \\
\hline União estável & 9 & 8,6 \\
\hline SeparadaNiưva & 15 & 14,3 \\
\hline \multicolumn{3}{|l|}{ Escolaridade } \\
\hline Nenhuma & 3 & 2,9 \\
\hline $1^{a}$ a $4^{a}$ série do ensino fundamental & 25 & 23,8 \\
\hline $5^{a}$ a $8^{a}$ série do ensino fundamental & 35 & 33,3 \\
\hline $2^{\circ} \mathrm{grau}$ & 39 & 37,1 \\
\hline Superior & 3 & 2,9 \\
\hline \multicolumn{3}{|l|}{ Atividade } \\
\hline Trabalha & 55 & 52,4 \\
\hline Näo trabalha & 46 & 43,8 \\
\hline Só estuda & 4 & 3,8 \\
\hline \multicolumn{3}{|l|}{ Atividade do parceiro $(n=99)^{*}$} \\
\hline Trabalha & 87 & 87,8 \\
\hline Não trabalha & 8 & 8,1 \\
\hline Só estuda & 3 & 3,0 \\
\hline \multicolumn{3}{|l|}{ Renda familiar } \\
\hline Até 2 salários mínimos & 53 & 50,5 \\
\hline 3 a 6 salários mínimos & 51 & 48,6 \\
\hline 7 a 10 salários mínimos & 1 & 1,0 \\
\hline
\end{tabular}

* excluídas seis mulheres que declararam não ter parceiro. 


\subsection{HISTÓRICO GINECO-OBSTÉTRICO E COMPORTAMENTAL}

$\mathrm{Na}$ tabela 2, observa-se que as pacientes tiveram, em média, dois filhos nascidos vivos, excetuando-se $15,2 \%$, que eram nuliparas. Das 89 mulheres multíparas, 1/5 mencionou a ocorrência de pelo menos um aborto espontâneo e apenas uma referiu um aborto provocado.

Quanto ao tipo de parto, verificou-se que pouco mais da metade das mulheres teve seus filhos somente através de parto normal, sendo que a média dessa categoria de parto foi de $2 \pm 2$, enquanto a de cesariana foi de $1 \pm 1$. O uso de algum método contraceptivo foi relatado pela maioria das pacientes, destacando-se o emprego de contraceptivo oral por $19,0 \%$ das argüidas, seguido de preservativo masculino com $18,1 \%$ das mulheres que fizeram seu uso, como método único. $A$ associação do uso de preservativo masculino com outros métodos foi verificada em $12,4 \%$ dos casos, e pouco mais de $1 / 5$ delas não usavam nenhum método contraceptivo, incluindo-se, nessa fração, todas as menopausadas.

Um percentual de $37,1 \%$ do universo de mulheres amostradas declarou ter se submetido de uma a três cauterizaçōes, na maioria dos casos, uma vez somente, e num período anterior a seis meses. Em relação à fisiologia menstrual, as participantes da pesquisa com ciclo normal compunha a maioria do grupo, com exceção de $3,8 \%$, que estavam em período de amamentação e $8,6 \%$ que eram menopausadas. 
Tabela 2. Histórico gineco-obstétrico das 105 mulheres.Tremembé, 2003.

\begin{tabular}{|c|c|c|c|}
\hline Caracteristicas & $\begin{array}{c}\text { Média e } \\
\text { desvio-padrão }\end{array}$ & $n$ & $\%$ \\
\hline Paridade & $2 \pm 2$ & & \\
\hline nenhum & & 16 & 15,2 \\
\hline 1 & & 27 & 26,7 \\
\hline 2 a 3 & & 36 & 34,3 \\
\hline 4 a 5 & & 19 & 18,1 \\
\hline 6 ou mais & & 6 & 5,7 \\
\hline Tipo de parto & & $n=89$ & 100,0 \\
\hline Só normal & & 51 & 57,3 \\
\hline Só cesariana & & 17 & 19,1 \\
\hline Normal + cesariana & & 21 & 23,6 \\
\hline Total de partos normais $=189$ & $2 \pm 2$ & & \\
\hline Total de partos cesarianas $=37$ & $1 \pm 1$ & & \\
\hline Mulheres com história de aborto & & $n=22$ & 100,0 \\
\hline provocados & & 1 & 4,5 \\
\hline espontâneos & & 21 & 95,4 \\
\hline 1 aborto & & 17 & 77,3 \\
\hline 2 abortos & & 3 & 13,6 \\
\hline 3 abortos & & 1 & 4,5 \\
\hline $\mathrm{N}^{\circ}$ de mulheres cauterizadas & & 39 & 37,1 \\
\hline Há menos de seis meses & & 4 & 10,3 \\
\hline Há mais de 6 meses & & 35 & 89,7 \\
\hline \multicolumn{4}{|l|}{ Métodos anticoncepcionais } \\
\hline Nenhum & & 22 & 21,0 \\
\hline Oral & & 20 & 19,0 \\
\hline Preservativo masculino & & 19 & 18,1 \\
\hline Dispositivo intra uterino & & 1 & 1,0 \\
\hline Progesterona injetável & & 5 & 4,8 \\
\hline Coito interrompido & & 3 & 2,9 \\
\hline Laqueadura / vasectomia do parceiro & & 17 & 16,2 \\
\hline Tabela de Ogino Knaus & & 5 & 4,8 \\
\hline Preservativo masculino + oral & & 10 & 9,5 \\
\hline Preservativo masculino + injetável & & 1 & 1,0 \\
\hline Preservativo masculino + coito interrompido & & 2 & 1,9 \\
\hline
\end{tabular}


$\mathrm{Na}$ tabela 3, são apontadas as características comportamentais e de risco para DST. O início da atividade sexual ocorreu em média aos $18 \pm 3$ anos com um percentual de $40,0 \%$ de mulheres que começaram a vida sexual entre 15 a 17 anos, e apenas $5,7 \%$ das mulheres não mantinham mais atividade sexual devido à separaçăo ou viuvez.

Cerca de $2 / 3$ das mulheres revelou que nunca fez uso de preservativo masculino, enquanto aquelas que têm o preservativo masculino como seu método eletivo de contracepção, fazem seu uso sempre. A maioria das mulheres, revelou que não era adepta do uso de ducha e/ou absorvente íntimo, ficando seu uso freqüente referido por uma minoria de $1,9 \%$ da população amostrada.

Em relação à atividade sexual das pesquisadas, constatou-se que $81,0 \%$ tinham parceiro fixo; $10,5 \%$ referiram relacionamento sexual com mais de um parceiro nos últimos três meses; e 2,8\% tiveram contato sexual com um novo parceiro no mesmo periodo de tempo. Nenhuma declarou ter se relacionado com outras mulheres ou ter se relacionado com homens e mulheres. 
Tabela 3. Características comportamentais e de risco para DST de 105 mulheres. Tremembé, 2003.

\begin{tabular}{|c|c|c|}
\hline $\begin{array}{c}\text { Média e desvio- } \\
\text { padrão }\end{array}$ & $n=$ & $\%$ \\
\hline Início da atividade sexual & & \\
\hline Menos de doze anos & 1 & 1,0 \\
\hline 12 a 14 anos & 11 & 10,5 \\
\hline 15 a 17 anos & 42 & 40,0 \\
\hline 18 a 20 anos & 33 & 31,4 \\
\hline 21 a 23 anos & 14 & 13,3 \\
\hline 24 a 26 anos & 4 & 3,8 \\
\hline \multicolumn{3}{|l|}{ Freqüência do uso de preservativo masculino } \\
\hline Nunca & 70 & 66,7 \\
\hline Às vezes & 16 & 15,2 \\
\hline Sempre & 19 & 18,1 \\
\hline \multicolumn{3}{|l|}{ Freqüência do uso de ducha elou absorvente íntimo } \\
\hline Nunca & 89 & 84,8 \\
\hline Às vezes & 14 & 13,3 \\
\hline Sempre & 2 & 1,9 \\
\hline \multicolumn{3}{|l|}{ Atividade sexual } \\
\hline Com parceiro fixo & 85 & 81,0 \\
\hline Com mais de um parceiro nos últimos três meses & 11 & 10,5 \\
\hline Com novo parceiro nos últimos três meses & 3 & 2,8 \\
\hline Não mantêm atividade sexual & 6 & 5,7 \\
\hline
\end{tabular}

A declaração de DST prévia ou outra condição clínica associada a esse grupo de doenças foi observada em pouco mais de $1 / 4$ das pacientes, destacando-se a ocorrência de parto prematuro em $12,4 \%$ dos casos, e de HPV, em $8,6 \%$. Também $1 / 5$ das mulheres referiu ocorrência de DST nos parceiros sexuais ou outras queixas clínicas da área genital deles, constatando-se que as mais freqüentes foram: ardência $(5,7 \%)$ e prurido no pênis $(4,7 \%)$. Foi relatado um caso de gonorréia, um de herpes genital e outro de corrimento, porém todos foram declarados como casos tratados e de ocorrência num periodo anterior a um ano da coleta desta pesquisa. As 
demais queixas, em sua maioria, também ocorreram num periodo anterior a um mês, e para $38,1 \%$ dos parceiros, segundo as pacientes, a menos de um mês (tabela 4).

Tabela 4. Histórico de DST de 105 mulheres. Tremembé, 2003

\begin{tabular}{|c|c|c|}
\hline Caracteristicas & $n$ & $\%$ \\
\hline \multicolumn{3}{|c|}{$\begin{array}{l}N^{0} \text { de mulheres com história de DST anterior ou outras } \\
\text { condições clinicas associadas }\end{array}$} \\
\hline Nenhuma & 75 & 71,4 \\
\hline Parto prematuro & 13 & 12,4 \\
\hline HPV & 9 & 8,6 \\
\hline DIP & 4 & 3,8 \\
\hline Gonorréia & 1 & 1,0 \\
\hline HIV & 1 & 1,0 \\
\hline Tricomoniase & 1 & 1,0 \\
\hline HIV+HPV & 1 & 1,0 \\
\hline \multicolumn{3}{|c|}{$\begin{array}{l}N^{0} \text { de mulheres com parceiros sexuais com história de DST } \\
\text { prévia ou outra queixa clínica na região genital }\end{array}$} \\
\hline Nenhum & 84 & 80,0 \\
\hline Ardência no pênis & 6 & 5,7 \\
\hline Prurido no pênis & 5 & 4,7 \\
\hline Irritação alérgica da pele do pênis & 2 & 1,9 \\
\hline Gonorréia & 1 & 1,0 \\
\hline Herpes & 1 & 1,0 \\
\hline Condiloma + HIV & 1 & 1,0 \\
\hline Corrimento & 1 & 1,0 \\
\hline Ferida purulenta no pênis & 1 & 1,0 \\
\hline Fissuras e prurido no pênis & 1 & 1,0 \\
\hline Verrugas na pele do pênis & 1 & 1,0 \\
\hline Prurido na virilha & 1 & 1,0 \\
\hline
\end{tabular}

Nenhuma paciente declarou ter procurado outro meio de tratamento a não ser o médico. Quando argüidas à respeito da ocorrência de outras 
doenças não ginecológicas, $26(24,7 \%)$ das pacientes fizeram referência principalmente a quadros de: hipertensão (7/26); diabetis mellitus (4/26); infecção do trato urinário inferior (3/26); hipotireoidismo (3/26); anemia (2/26); e bronquite (2/26).

No entanto, pouco menos da metade delas relatou o uso de algum medicamento continuo, sendo a hidroclorotiazida e hormônios tireoidianos os mais citados. Apenas uma paciente menopausada fazia uso de terapia de reposição hormonal e todas as pacientes declararam procurar sempre o médico, para qualquer tipo de tratamento.

\subsection{AVALIAÇÃO CLÍNICA, DIAGNÓSTICO E TRATAMENTO}

Os motivos da consulta expressos pelas pacientes são apresentados na tabela 5, e compreendem: as principais queixas clínicas e/ou a realização do teste preventivo de Papanicolaou, motivos pelos quais as mulheres procuraram o ambulatório de ginecologia.

Apenas a realização do exame preventivo foi o motivo responsável por $10,5 \%$ das consultas, enquanto que a percepção só de corrimento foi a razão da consulta de $20,0 \%$ das mulheres.

A associação de corrimento a outros sinais e sintomas foi referida como causa da consulta de $29,5 \%$ do total de mulheres; já a visita ao médico, para $9,5 \%$ das pacientes foi devida à realização do teste preventivo, além da presença de outros sinais e sintomas clínicos; e ainda, 10,5\% referiram que o motivo da consulta era para realização do exame preventivo, além de, corrimento e outra queixa. 
Tabela 5. Motivos da consulta ginecológica referidos pelas 105 mulheres. Tremembé, 2003.

\begin{tabular}{lcc}
\hline Motivos da consulta & $n$ & $\%$ \\
\hline Preventivo & 11 & 10,5 \\
Corrimento & 21 & 20,0 \\
Corrimento + outra queixa associada \# & 31 & 29,5 \\
Preventivo*+corrimento & 21 & 20,0 \\
Preventivo e outra queixa associada\# menos corrimento & 10 & 9,5 \\
Preventivo + corrimento + outra queixa associada\# & 11 & 10,5 \\
\hline
\end{tabular}

* Exame preventivo de Papanicolaou " dor ou desconforto pélvico e/ou prurido

A realização de pelo menos um teste de Papanicolaou anterior à coleta da pesquisa foi referida por $95,2 \%$ das mulheres. Cerca de $13,0 \%$ dessas pacientes afirmou ter recebido um resultado anormal do exame colpocitológico que compreendia, na maioria das vezes, a quadro citológico de HPV associado ou não à neoplasia intra-epitelial cervical (NIC) (tabela 6).

Tabela 6. Histórico do exame preventivo de Papanicolaou de 105 mulheres. Tremembé, 2003

\begin{tabular}{cccc}
\hline Realização do teste de Papanicolaou anterior & $\boldsymbol{n}$ & $\%$ \\
\hline Não & & 5 & 4,8 \\
$\operatorname{Sim}$ & 100 & 95,2 \\
\hline Resultado do citopatológico anterior & & \\
& Normal & 73 & 73,0 \\
& Anormal HPV e/ou NIC & 13 & 13,0 \\
& Ignorado & 14 & 14,0 \\
\hline
\end{tabular}

A avaliação clínica deu ênfase à utilização do fluxograma da abordagem sindrômica para o diagnóstico e tratamento dos corrimentos vaginais (anexo 1)

Os achados clínicos foram distribuidos na tabela 7 , verificando-se que mais da metade das mulheres atendidas apresentava colo normal e 
$19,0 \%$ apresentavam ectrópio. Na presença de colo friável ao toque ou dor à mobilização do colo ou anexos, independentemente de outras combinações clínicas, tais como presença de hiperemia, colpite e/ou ectrópio, essas alterações foram estratificadas numa só variável, pois tratavam-se de quadros sugestivos de cervicite por $C$. trachomatis ou $N$. gonorrhoeae. Portanto, segundo o preconizado pelo MINISTÉRIO DA SAÚDE (1999), $14,3 \%$ das mulheres apresentaram aspectos clínicos que poderiam sugerir a presença dessas infecções.

Tabela 7. Achados clínicos no colo uterino de 105 mulheres. Tremembé, 2003.

\begin{tabular}{lcc}
\hline Achados na inspeção clínica do colo uterino & $n$ & $\%$ \\
\hline Normal & 63 & 60,0 \\
Colpite e/ou hiperemia & 7 & 6,7 \\
Ectrópio (ulcerado ou não, associado à colpite ou não) & 20 & 19,0 \\
$\begin{array}{l}\text { Ectrópio, colpite, colo ulcerado (associados à friabilidade ao toque } \\
\text { e/ou dor à mobilização do colo e anexos) }\end{array}$ & 15 & 14,3 \\
\hline
\end{tabular}

Todas as pacientes participantes do estudo apresentaram leucorréia, variando quanto ao aspecto. Dessa forma, na tabela 8, a distribuição dessas características podem ser evidenciadas. Os aspectos de maior freqüência foram leucorréia em grande quantidade, de cor branca, aspecto mucoso e com cheiro ausente, registrando percentuais de $41,9 \%$; $75,2 \% ; 56,2 \%$ e $93,3 \%$, respectivamente.

Notou-se ainda que a combinação "pouca quantidade, cor branca, consistência mucosa e cheiro ausente" foi observada em $19,0 \%$ das mulheres; seguida de "quantidade moderada, cor branca, consistência mucosa e cheiro ausente" em 13,3\% pacientes; e "quantidade grande, cor branca, consistência mucosa e cheiro ausente" em 10,5\% mulheres. 
Tabela 8. Leucorréia em 105 pacientes. Tremembé, 2003.

\begin{tabular}{|c|c|c|}
\hline Aspecto da leucorréia & $n$ & $\%$ \\
\hline \multicolumn{3}{|l|}{ Quantidade } \\
\hline Grande & 44 & 41,9 \\
\hline Moderada & 26 & 24,8 \\
\hline Pouca & 35 & 33,3 \\
\hline \multicolumn{3}{|l|}{ Cor } \\
\hline Branca & 79 & 75,2 \\
\hline Amarelada & 10 & 9,5 \\
\hline Acinzentada & 7 & 6,7 \\
\hline Esverdeada & 1 & 1,0 \\
\hline Sanguinolenta & 8 & 7,6 \\
\hline \multicolumn{3}{|l|}{ Consistência } \\
\hline Aquoso & 4 & 3,8 \\
\hline Pastoso & 19 & 18,1 \\
\hline Mucoso & 59 & 56,2 \\
\hline Bolhoso & 16 & 15,2 \\
\hline Aderente à parede & 7 & 6,7 \\
\hline \multicolumn{3}{|l|}{ Cheiro } \\
\hline Ausente & 98 & 93,3 \\
\hline Ácido & 5 & 4,8 \\
\hline Peixe & 2 & 1,9 \\
\hline
\end{tabular}

No consultório foram aplicados os testes de "Whiff", "Schiller" e realizada a medida de $\mathrm{pH}$ das secreções, para o clínico concluir o diagnóstico e instituir o tratamento, empregando também, o escore de risco. Os resultados podem ser observados na tabela 9 .

O teste de "Whiff" foi positivo em $23,8 \%$ dos casos, enquanto a medida do $\mathrm{pH}$ foi maior que 4,5 em $38,1 \%$ das pacientes. $O$ teste de "Schiller" foi positivo em $1 / 4$ da população estudada. Quanto ao escore de risco para o diagnóstico de cervicite por $C$. trachomatis ou $N$. gonorrhoeae, 
verificou-se que $4,8 \%$ das mulheres apresentavam fatores de risco para os agravos.

Tabela 9. Resultados dos testes realizados no consultório e escore de risco de 105 mulheres. Tremembé, 2003

\begin{tabular}{ccc}
\hline Resultados dos testes clínicos e escore de risco & $n$ & $\%$ \\
\hline Teste de "Whiff" & 65 & 61,9 \\
Negativo & 25 & 23,8 \\
Positivo & 15 & 14,3 \\
Fracamente positivo & & \\
\hline Teste de "Shiller" & 78 & 74,3 \\
Negativo & 27 & 25,7 \\
Positivo & & \\
Medida do pH & 65 & 61,9 \\
$\leq 4,5$ & 40 & 38,1 \\
$>4,5$ & & \\
Escore de Risco* & 81 & 77,0 \\
0 & 19 & 18,1 \\
1 & 5 & 4,8 \\
2 & &
\end{tabular}

* Escore $\geq 2$, considera-se paciente de risco para gonorréia e/ou infecção por $C$. trachomatis (MINISTÉRIO DA SAÚDE 1999).

A partir da história clínica, do escore de risco e dos testes realizados no consultório, o clínico firmou seu diagnóstico, prescrevendo o tratamento, quando necessário, e esses dados estão descritos na tabela 10.

Mais da metade da população da pesquisa apresentou alguma alteração cérvico-vaginal. De acordo com o ginecologista, $18,1 \%$ dos quadros clínicos eram de vaginose bacteriana elou tricomoniase e 9,5\% eram de candidiase. 
Os diagnósticos de C. trachomatis foram caracterizados por aspectos clínicos do colo, típicos de infecção por C. trachomatis e/ou gonorréia, bem como pelos escores de risco. Dos $18,1 \%$ de casos sugestivos dessa infecção, $13,3 \%$ estavam associados à vaginoses ou vaginites. Havia associação de quadros de vaginose bacteriana e/ou tricomoníase ou candidiase ou cervicite em mais da metade dos casos. Dois casos de vulvovaginites foram associados à infecção por $C$. trachomatis, pois as pacientes apresentaram escore de risco igual a 2. Em nenhum caso foi observada a presença de mucopus exclusivamente para classificar o caso como cervicite. Cerca de $5,7 \%$ de mulheres, apresentaram cervicite, considerada de outra causa, e não associada a nenhum agente em estudo.

Tabela 10. Diagnóstico clínico de 105 mulheres. Tremembé, 2003

\begin{tabular}{lcc}
\hline Diagnóstico & $n$ & $\%$ \\
\hline Normal & 45 & 42,9 \\
Cervicite+vaginose bacterianae/ou tricomoníase & 4 & 3,8 \\
Candidiase & 10 & 9,5 \\
Cervicite+candidiase & 1 & 1,0 \\
C. trachomatis & 5 & 4,8 \\
Vaginose bacteriana e/ ou tricomoniase & 19 & 18,1 \\
C. trachomatis + candidiase & 4 & 3,8 \\
C. trachomatis + vaginose bacteriana e/ ou tricomoniase & 10 & 9,5 \\
Cervicite & 6 & 5,7 \\
Vaginose bacteriana+candidiase & 1 & 1,0 \\
\hline
\end{tabular}

Todas as pacientes e seus parceiros foram tratados, segundo o esquema terapêutico recomendado pelo MINISTÉRIO DA SAÚDE (1999) para tratamento de corrimentos vaginais, quando se emprega a abordagem sindrômica para esse fim.

Dessa forma, conforme a disponibilidade de medicamentos no Centro de Saúde de Tremembé, foi prescrito metronidazol para $28,3 \%$ 
(17/60) das pacientes; tinidazol para $13,3 \%$ (8/60) e cetoconazol para $11,7 \%$ (8/60). A eritromicina foi o antimicrobiano de eleição para os casos de cervicite mucopurulenta, o qual, foi prescrito associado ao metronidazol em 8,3\% (5/60) dos casos. Em oito casos, a critério do ginecologista, foi prescrito o ácido metacresossulfônico com metanal (tabela 11) e, nos casos das três vulvovaginites com um perfil também de gonorréia ou infecção por C. trachomatis, o clínico optou pelo tratamento convencional das vulvovaginites, às quais, estavam associadas, sem administrar antimicrobianos.

Por opção do clínico, $30,2 \%$ dos parceiros de pacientes com vaginose bacteriana e candidiase também foram tratados, sendo administrados os mesmos medicamentos daqueles administrados às suas mulheres, em dose única.

Tabela 11. Medicamentos prescritos para o tratamento de 60 pacientes. Tremembé, 2003

\begin{tabular}{lcc}
\hline Principio ativo & $n$ & $\%$ \\
\hline Metronidazol & 17 & 28,3 \\
Tinidazol & 8 & 13,3 \\
Ácido metacresossulfônico com metanal & 8 & 13,3 \\
Cetoconazol & 7 & 11,7 \\
Metronidazol+eritromicina & 5 & 8,3 \\
Doxiciclina & 3 & 5,0 \\
Metronidazol+tinidazol & 2 & 3,3 \\
Tioconazol+tinidazol & 2 & 3,3 \\
Ácido metacresossulfônico com metanal + metronidazol & 1 & 1,7 \\
Ácido tricloacético & 1 & 1,7 \\
Azitromicina+metronidazol & 1 & 1,7 \\
Fluconazol & 1 & 1,7 \\
Fluconazol+tinidazol & 1 & 1,7 \\
Miconazol & 1 & 1,7 \\
Tinidazol+vibramicina & 1 & 1,7 \\
Tioconazol+tinidazol e cloridrato de tetraciclinatanfotericina B & 1 & 1,7 \\
\hline
\end{tabular}




\subsection{RESULTADOS DAS ANÁLISES LABORATORIAIS}

$\mathrm{Na}$ tabela 12 são apontados os resultados obtidos no exame direto "a fresco" das secreções vaginais, verificando-se que a positividade do teste foi mais freqüente pela presença de clue cells em $18,1 \%$ dos casos, seguida de blastoconídios e/ou hifas com $9,5 \%$.

Houve, ainda, associação de clue cells e blastoconídios e/ou hifas em 2,9\% das pacientes. Trichomonas vaginalis móveis foram observadas apenas em dois casos, estando um deles também associado à presença de blastoconídios e/ou hifas.

Tabela 12. Resultados do exame direto "a fresco" de secreção vaginal de 105 pacientes. Tremembé, 2003.

\begin{tabular}{ccc}
\hline Resultado & $n$ & $\%$ \\
\hline Negativo & 71 & 67,6 \\
Positivo & 34 & 32,4 \\
\hline Trichomonas vaginalis & 1 & 1,0 \\
Leveduras e/ou hifas & 10 & 9,5 \\
Clue cells & 19 & 18,1 \\
Leveduras e/ou hifas + clue cells & 3 & 2,9 \\
Levedura e ou hifas + Trichomonas vaginalis & 1 & 1,0 \\
\hline
\end{tabular}

Os resultados das análises das secreções obtidas da endocérvice e do fundo de saco vaginal, coradas pelo método de Gram são apresentados na tabela 13. Em relação à secreção endocervical, verificou-se que $38,1 \%$ dos casos tinham uma contagem de leucócitos maior ou igual a 10 células, em campo de aumento de 1000 vezes, porém não se evidenciou nenhum diplococo intracelular no material analisado. 
O quadro de vaginose bacteriana, que foi caracterizado pela presença de mais de $20 \%$ do esfregaço com presença de clue cells e escore de sete ou mais, esteve presente em $18,1 \%$ dos casos, além das combinações de vaginose bacteriana e candidiase, que foram detectadas em 2,9\% das pacientes. A presença de blastoconídios e/ou hifas sugestivas de Candida sp e Trichomonas vaginalis, também foi observada em percentuais de $13,3 \%$ e 1,9\% respectivamente, considerando-se o agente, independentemente de associações entre si ou com outros morfotipos bacterianos. Uma flora mista de cocos e bacilos foi notada em secreções vaginais de $10,5 \%$ das mulheres. Salienta-se ainda a ocorrência do quadro citolítico por lactobacilos em $8,3 \%$ dos esfregaços analisados.

Tabela 13. Resultados das análises laboratoriais de esfregaços corados pelo método de Gram, obtidos de 105 mulheres. Tremembé, 2003.

\begin{tabular}{|c|c|c|}
\hline Lâminas coradas pelo método de Gram & $n$ & $\%$ \\
\hline \multicolumn{3}{|l|}{ Esfregaço endocervical } \\
\hline \multicolumn{3}{|l|}{ Contagem de leucócitos } \\
\hline$<10 /$ campo/1000X & 65 & 61,9 \\
\hline$\geq 10 /$ campo/1000X & 40 & 38,1 \\
\hline \multicolumn{3}{|l|}{ Esfregaço de fundo de saco vaginal } \\
\hline Flora normal & 33 & 31,4 \\
\hline Flora intermediária & 19 & 18,1 \\
\hline Vaginose bacteriana & 19 & 18,1 \\
\hline Flora mista & 11 & 10,5 \\
\hline Flora normal + citólise & 8 & 7,6 \\
\hline Candidiase +flora normal & 5 & 4,8 \\
\hline Candidiase + vaginose bacteriana & 3 & 2,9 \\
\hline Candidiase + flora mista & 3 & 2,9 \\
\hline Tricomoníase + candidiase + flora intermediária & 1 & 1,0 \\
\hline Candidiase + flora lintermediária & 1 & 1,0 \\
\hline Tricomoniase +flora mista & 1 & 1,0 \\
\hline Candidíase + flora normal + citólise & 1 & 1,0 \\
\hline
\end{tabular}


Quanto às culturas realizadas, verificou-se que nenhuma das pacientes do estudo apresentou cultura positiva para gonorréia, enquanto nas culturas para fungo, todos casos positivos $(17,1 \%)$ foram identicados como sendo do gênero Candida e, em todos eles, identificou-se apenas a espécie albicans.

A pesquisa de Chlamydia trachomatis por imunofluorescência direta, detectou três casos, pela presença, de pelo menos, 10 corpúsculos elementares verdes fluorescentes e de, no mínimo, 5 células epiteliais no material analisado, para considerá-lo adequado. Esses resultados estão expressos na tabela 14.

Tabela 14. Resultados microbiológicos obtidos em secreções cérvico-vaginais de 105 mulheres. Tremembé, 2003.

\begin{tabular}{ccc}
\hline Resultados microbiológicos & $\boldsymbol{n}$ & $\%$ \\
\hline Culturas negativas & 87 & 82,8 \\
Culturas positivas & 18 & 17,1 \\
\hline Neisseria gonorrhoeae & 0 & 0,0 \\
Candida sp & 18 & 17,1 \\
\hline Pesquisa de Chlamydia trachomatis & 3 & 2,9 \\
\hline
\end{tabular}

A tabela 15 mostra os resultados da avaliação oncótica de esfregaços cérvico-vaginais corados pelo método de Papanicolaou. Os resultados dessa avaliação foram compilados com base nos dados emitidos no modelo adaptado (anexo 3 ) de requisição de exame preventivo de câncer 
do colo uterino do Programa Viva Mulher que é utilizado para o cadastro no Sistema de Informação do Câncer do Colo do Útero - SISCOLO estabelecido pelo MINISTÉRIO DA SAÚDE (INCA 2002), o qual é empregado nos serviços de citopatologia da rede pública.

Verificou-se que $83,8 \%$ pacientes apresentavam quadro citológico inflamatório e, em $47,6 \%$, notou-se a presença de metaplasia escamosa. Foram registrados dois casos de efeito citopático sugestivo de infecção por HPV e dois casos de NIC II, nos quais, não foi visualizada qualquer alteração sugestiva de efeito virótico nas células epiteliais.

Tabela 15. Resultados da avaliação oncótica das secreções cérvico-vaginais coradas pela técnica de Papanicolaou de 105 mulheres. Tremembé, 2003.

\begin{tabular}{lcc}
\hline Resultados da avaliação oncótica & $n$ & $\%$ \\
\hline $\begin{array}{c}\text { Dentro dos limites da normalidade } \\
\text { Sem células anormais }\end{array}$ & 13 & 12,4 \\
\hline Alteraçōes celulares benignas (reativas ou reparativas) & 36 & 34,3 \\
Inflamação & 50 & 47,6 \\
Inflamação com metaplasia escamosa & 2 & 1,9 \\
Atrofia com inflamaçăo & 2 & 1,9 \\
\hline Alteraçōes em células epiteliais escamosas & 2 & 1,9 \\
Efeito citopático compativel com HPV & 2 &
\end{tabular}

Em relação aos resultados microbiológicos dos esfregaços corados pelo método de Papanicolaou, esses podem ser vistos na tabela 16, notando-se que mais da metade dos esfregaços apresentou flora de bacilos de Döderlein de permeio às células epiteliais, ressaltando-se que, em 7,6\% das lâminas, foi apontado quadro de citólise. Em 12,4\% dos esfregaços. foi sugerida a presença de flora de Gardnerella vaginalis; $13,3 \%$ apresentaram 
flora mista e $8,3 \%$ tinham flora bacilar. A presença de Trichomonas vaginalis foi visualizada em $3,8 \%$ das lâminas, associada à flora bacilar ou mista e à leveduras assinaladas como Candida sp, segundo o protocolo do INCA (2002), em 4,8\%. Houve também a indicação de um caso sugestivo de infecção por Chlamydia trachomatis.

Tabela 16. Resultados da avaliação microbiológica das secreções cérvico-vaginais coradas pela técnica de Papanicolaou das 105 mulheres. Tremembé, 2003.

\begin{tabular}{lcc}
\hline \multicolumn{3}{c}{ Resultados da avaliação microbiológica pelo método de Papanicolaou } \\
\hline Bacilos de Döderlein & $n=105$ & $\%$ \\
Bacilos de Döderlein + Citólise & 50 & 47,6 \\
Gardnerella vaginalis & 8 & 7,6 \\
Flora mista & 13 & 12,4 \\
Flora bacilar & 14 & 13,3 \\
Candida sp + bacilos de Döderlein & 9 & 8,6 \\
Trichomonas vaginalis + flora mista & 5 & 4,8 \\
Flora cocóide & 2 & 1,9 \\
Trichomonas vaginalis + flora bacilar & 1 & 1,0 \\
Sugestivo de Chlamydia sp + flora bacilar & 2 & 1,9 \\
\hline
\end{tabular}

Quanto aos critérios sugeridos neste trabalho para indicação de cervicite, por meio da leitura complementar das lâminas coradas pelo método de Papanicolaou, em que se fez uma avaliação semiquantitativa da presença de leucócitos, acompanhada de presença de células endocervicais reativas e/ou metaplasia com vacúolos sem inclusão, verificou-se que $34,3 \%$ apresentou contagem de leucócitos equivalente a duas cruzes (2+), correspondendo a mais da metade células epiteliais, obscurecidas por leucócitos polimorfonucleares, em cinco campos não-adjacentes, empregando aumento de 400 vezes. Células endocervicais com características reativas estiveram presentes em $40 \%$ das lâminas e 
metaplasia escamosa com vacúolos sem inclusão foi perceptivel em $26,7 \%$. Considerando-se as combinações que poderiam sugerir quadro de cervicite por Chlamydia trachomatis, notou-se que $21,9 \%$ dos esfregaços contemplavam os quesitos, como mostra a tabela 17.

Tabela 17. Resultados da leitura complementar realizada em esfregaços corados por Papanicolaou de 105 mulheres, para indicação de cervicite. Tremembé, 2003.

\begin{tabular}{ccc}
\hline Critérios & $n$ & $\%$ \\
\hline Contagem de leucócitos (L) & & \\
Zero & 51 & 15,2 \\
$1+$ & 38 & 36,2 \\
$2+$ & 42 & 40,0 \\
\hline Células endocervicais reativas (CER) & & \\
\hline Metaplasia escamosa com vacúolos sem inclusões(MEV) & 28 & 26,7 \\
& & \\
\hline Combinações de critérios na mesma paciente & 19 & 18,1 \\
L 2+; CER; MEV & 4 & 3,8 \\
L 2+; CER & 2 & 1,9 \\
L 2+; MEV & 13 & 12,4 \\
L 2+ & \multicolumn{3}{c}{4} \\
\hline
\end{tabular}

\subsection{ANÁLISE ESTATÍSTICA}

\subsubsection{Prevalência, Sensibilidade, Especificidade e Valor Preditivo Positivo}

Na tabela 18, observa-se a distribuição da taxa de prevalência dos principais agentes causais envolvidos em quadros de corrimento vaginal, determinados por métodos considerados como padrão "ouro" neste estudo. 
Para efeito dos cálculos da prevalência e testes de sensibilidade, especificidade e valores preditivos positivos, considerou-se como padrão "ouro" os resultados obtidos nas culturas para fungos e N. gonorrhoeae, bem como da pesquisa de $C$. trachomatis obtida por imunofluorêscencia direta. Para Trichomonas vaginalis, considerou-se a positividade obtida em três testes realizados simultaneamente, ou seja, no exame direto "a fresco", Gram e Papanicolaou.

O quadro de vaginose bacteriana foi considerado positivo quando, na mesma paciente, obteve-se: teste de "Whiff" positivo ou fracamente positivo e/ou medida do $\mathrm{pH}$ superior a 4,5 ; presença de pelo menos $20 \%$ de clue cells no exame direto "a fresco" ou Gram; e escore de Nugent no esfregaço corado pelo Gram superior a 7.

Tabela 18. Taxa de prevalência de agentes causais associados a corrimento vaginal em 105 mulheres. Tremembe, 2003.

\begin{tabular}{lcc}
\hline Agentes causais * $^{*}$ & $\boldsymbol{n}$ & $\%$ \\
\hline T.vaginalis & 2 & 1,9 \\
C. trachomatis & 3 & 2,8 \\
Candida albicans & 18 & 17,1 \\
Bactérias (vaginose bacteriana) & 18 & 17,1 \\
\hline
\end{tabular}

* Não foi detectado nenhum caso de $N$. gonorrhoeae em cultura.

A distribuição percentual de todos os diagnósticos etiológicos e associações, os quais foram obtidos pelo emprego da abordagem sindrômica para corrimentos vaginais e pelos métodos de Papanicolaou e Gram, foram comparados com os diagnósticos considerados padrão "ouro" (tabela 19). 
Do total de culturas positivas para C. albicans, houve associações com vaginose bacteriana em $4(3,8 \%)$ de casos e tricomoníase em $1(1,0 \%)$. Observou-se vaginose bacteriana associada à $C$. trachomatis, também em $1,0 \%$ de casos. Foram descartados quatro resultados de vaginose bacteriana que, embora fossem positivos no método de Gram, não contemplaram os outros quesitos, ou seja, medida de $\mathrm{pH}>4,5$ e teste de "Whiff" positivo.

Para o diagnóstico clínico sugestivo de cervicite por $C$. trachomatis, foram considerados os parâmetros recomendados pelo MINISTÉRIO DA SAÚDE (1999), ou seja, um escore de risco maior igual a 2 ou colo friável ou dor à mobilização do colo e/ ou anexos, sendo que a presença de qualquer um desses parâmetros sugere cervicite por $C$. trachomatis elou por $N$. gonorrhoeae. Nesse grupo também foram incluídos casos de vaginites e vaginoses, quando estavam associadas aos parâmetros descritos.

$\mathrm{Na}$ abordagem sindrônica, o diagnóstico de cervicite por outras causas, quando estava associado a quadros de vaginites ou vaginoses, foi analisado em conjunto ao diagnóstico de candidíase elou vaginose e tricomoníase. Os quadros de cervicite sem associação clínica a nenhum dos agentes em estudo, foram agrupados como casos "negativos".

Assim, empregando-se a abordagem sindrômica, foi emitido um diagnóstico de vaginose bacteriana para $16,2 \%$ das pacientes e $10,5 \%$ de candidiase. A cervicite sugestiva de gonorréia ou infecção por $C$. trachomatis foi observada em $3,8 \%$ dos casos, e associada com quadros de vaginites e vaginoses, foi notada em $14,3 \%$ mulheres.

A contagem de leucócitos $210 /$ campo/1000X no esfregaço endocervical corado por Gram também foi considerada como diagnóstico sugestivo de cervicite. Vale ressaltar que houve uma correlação total dos 
resultados bacterioscópicos em relação à identificação de clue cells e de blastoconidios ou pseudo-hifas, os quais foram visualisados simultaneamente em secreções da mesma paciente.

Já pelo método de Papanicolaou, menos da metade dos diagnósticos de candidíase foi relatado e nenhuma co-infecção pode ser observada; no entanto, a tricomoniase foi atestada em quatro pacientes. Pelo método de Gram, considerando-se apenas a contagem de leucócitos, $38,1 \%$ de cervicites foram sugeridas. 
Tabela 19. Distribuição do número e percentual de diagnósticos etiológicos dos agentes em estudo e associações, na secreção cérvico-vaginal de 105 mulheres, obtidos pelos métodos considerados padrão "ouro", na abordagem sindrômica, Papanicolaou e Gram. Tremembé, 2003

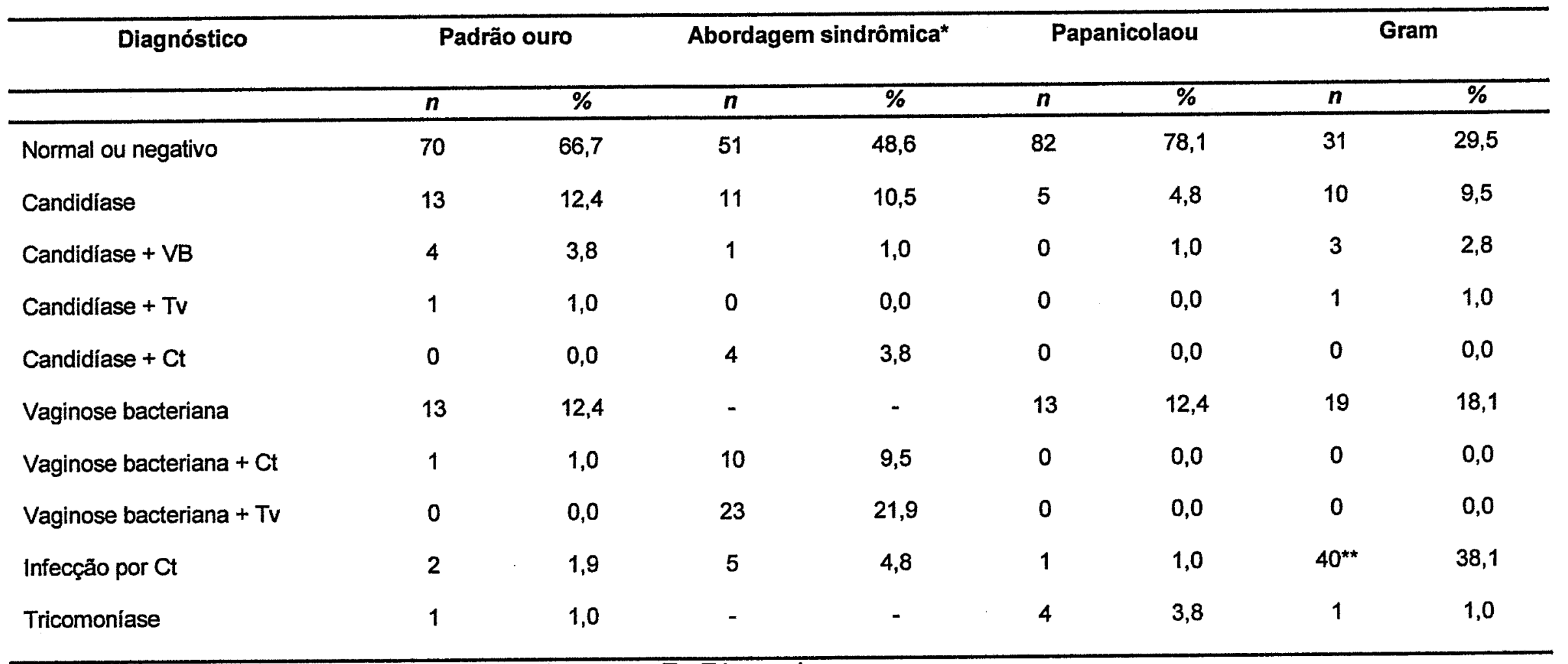

$\mathrm{Ct}=$ Chlamydia trachomatis $\mathrm{VB}=$ vaginose bacterina TV=Tricomoníase

*Na abordagem sindrômica a vaginose bacteriana e tricomoníase foram diagnosticados em conjunto

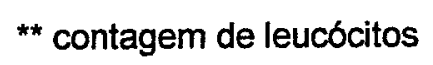


A tabela 20 relaciona os valores de sensibilidade, especificidade e valor preditivo positivo, calculados com intervalo de confiança de $95 \%$, para os métodos diagnósticos em estudo. Nota-se que os melhores resultados foram alcançados por meio dos exames bacterioscópicos, em relação ao diagnóstico de candidíase, vaginose bacteriana e tricomoníase, nos quais os resultados de falso-negativos foram bem menores daqueles obtidos pelo Papanicolaou ou pela abordagem sindrômica. Porém, no caso do diagnóstico das cervicites pela simples contagem de leucócitos, observou-se baixo desempenho do teste tanto na sensibilidade como na especificidade, tendo $5 \%$ de chance apenas, para identificar um verdadeiro caso positivo.

A cervicite diagnosticada por meio da abordagem sindrômica, obteve um taxa de $66,7 \%$ de sensibilidade, porém um valor preditivo positivo de apenas $10,5 \%$, correspondendo, a esse pequeno percentual, a probabilidade de que essa metodologia, idendifique casos que sejam realmente positivos.

O diagnóstico de candidiase foi aquele que obteve os menores percentuais de sensibilidade em todos os testes e a vaginose bacteriana foi diagnosticada com ótima sensibilidade nos exames bacterioscópicos alcançando $100,0 \%$.

A especificidade foi boa em todos os métodos diagnósticos, assim, todos eles são capazes de identificar os verdadeiros casos negativos. 
Tabela 20. Distribuição dos percentuais de sensibilidade (S), especificidade (E) e valor preditivo positivo (VPP) dos diagnósticos de corrimentos vaginais de 105 mulheres, realizados empregando-se a abordagem sindrômica, método de Papanicolaou, método de Gram e exame direto "a fresco". Tremembé, 2003.

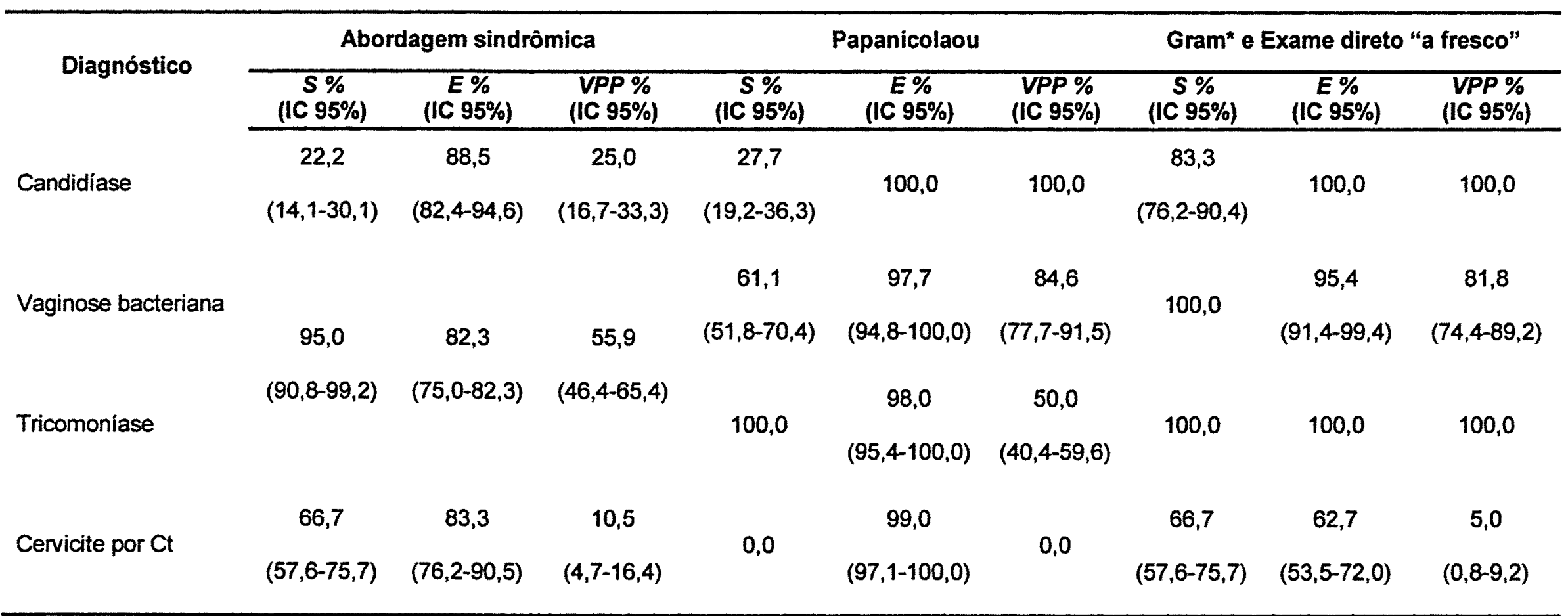

\footnotetext{
$\mathrm{Ct}=$ Chlamydia trachomatis

IC = Intervalo de confiança
}

* a identificação presuntiva de cervicite por $C$. trachomatis foi realizada pela contagem de leucócitos nos esfregaços endocervicais corados por Gram apenas e não no exame direto. 


\subsubsection{ESCORES DE RISCO}

Para determinar fatores individuais da população em estudo, relacionados com as DST, foi realizada análise univariada, com finalidade de observar-se a significância desses fatores, bem como foi aplicado o teste razão de odds (odds ratio $=$ OR), com intervalo de confiança de $95 \%$. Todas as tabelas, cujas categorias permitiram uma reoganização no formato $2 \times 2$, foram reestruturadas para adequar a análise, de acordo com o programa estatístico aplicado SAS (Statistical Analysis System ).

Para os critérios propostos nesse estudo como indicadores de uma infecção por $C$. trachomatis, em secreções coradas pelo método de Papanicolaou, obteve-se os resultados de sensibilidade, especificidade e valor preditivo positivo (intervalo de confiança de $95 \%$ ), como mostra a tabela 21 . O critério de metaplasia escamosa com presença de vacúolos sem inclusão, quando considerado isoladamente, foi significamente estatístico $(p=0,0262)$ e $O R=12$. Esse parâmetro foi $100,0 \%$ sensivel, tendo regular especificidade, porém com valor preditivo positivo baixo. As demais variaveis, não foram significativas.

O diagnóstico sugestivo de cervicite englobava a presença de leucócitos no esfregaço, avaliados como $2+$, associada à presença de células endocervicais reativas e/ou de metaplasia escamosa com vacúolos, sem inclusão citoplasmática, na mesma paciente. Essa associação foi significativa $(p=0,0262)$ e indicou risco superior a 5 vezes de ter a doença. Quanto à sensibilidade e especificidade, observaram-se percentuais de $66,7 \%$ e $83,3 \%$, respectivamente, e valor preditivo de apenas $10,5 \%$.

A contagem de leucócitos no método de Gram, não foi significativa estatisticamente. 
Tabela 21. Sensibilidade (S), especificidade (E), valor preditivo positivo (VPP) e razão de proporções (ODDS) com nível de significância (p) de $95 \%$ dos critérios indicadores de cervicite em esfregaços corados pelo método de Papanicolaou. Tremembé, 2003.

\begin{tabular}{lccccc}
\hline \multicolumn{1}{c}{ Critérios } & $\begin{array}{c}\text { S \% } \\
\text { (IC 95\%) }\end{array}$ & $\begin{array}{c}E \% \\
\text { (IC 95\%) }\end{array}$ & $\begin{array}{c}\text { VPP \% } \\
\text { (IC 95\%) }\end{array}$ & $\begin{array}{c}\text { ODSS } \\
\text { (IC 95\%) }\end{array}$ & $p=$ \\
\hline $\begin{array}{l}\text { Metaplasia escamosa com } \\
\text { vacúolos sem inclusões (MEV) }\end{array}$ & 100,0 & $\begin{array}{c}72,5 \\
(64,0-81,1)\end{array}$ & $\begin{array}{c}9,7 \\
(4,0-15,3)\end{array}$ & 12,6668 & 0,00262 \\
\hline $\begin{array}{l}\text { Combinações de critérios na } \\
\text { mesma paciente }\end{array}$ & & & & & \\
\multicolumn{1}{l}{ L 2+ CER; MEV } & $\begin{array}{c}66,7 \\
(57,6-75,7)\end{array}$ & $\begin{array}{c}83,3 \\
(76,2-90,5)\end{array}$ & $\begin{array}{c}10,5 \\
(4,7-16,4)\end{array}$ & 5,3182 & 0,0262 \\
\hline
\end{tabular}

IC = intervalo de confiança

\subsubsection{Avaliação do perfil sociodemográfico, comportamental e clinico-laboratorial como risco para mulheres com DST}

A partir das cinco pacientes $(5,8 \%)$ que apresentaram tricomoníase e infecção por $C$. trachomatis confirmados pelos métodos de padrão "ouro", foram analisadas as características que tiveram expressão estatística para a pesquisa (Tabela 22).

Para a maioria das mulheres com DST a escolaridade era até a $8^{\mathrm{a}}$ série do ensino fundamental; o estado marital era de união estável; e a renda familiar de até dois salários mínimos. $A$ atividade sexual iniciou-se, para a maioria, na faixa de 17 anos ou mais e tiveram dois ou mais filhos, através de parto normal. Nenhuma delas referiu parto cesariana, aborto, parto prematuro, DIP ou DST anterior.

Em relação ao método contraceptivo, três tomavam pílula anticoncepcional, e apenas uma, declarou o uso esporádico de preservativo 
masculino. Todas procuraram o serviço, com no mínimo, queixa de corrimento e uma citou o resultado anormal do preventivo anterior. No entanto, verificou-se que nenhuma variável demográfica e gineco-obstétrica teve significância estatística, nem representou fator de risco $(p \geq 0,10)$.

Por outro lado, observou-se que a variável do comportamento sexual, em relação a ter mais de um parceiro nos últimos três meses e novo parceiro no mesmo período de tempo, foi estatisticamente significativa com valores de $p=0,0995$ e 0,0026 , respectivamente, tendo no primeiro caso, risco de 4,8 , e no segundo, 32,6 superior de ter DST, do que aquelas mulheres que não tiveram esse comportamento.

Dentre as variavéis clínicas, foram significativas: cor da leucorréia "amarela ou outra" ( $p=0,0871)$, com risco 5 vezes maior para ocorrência de DST; $p H>4,5(p=0,0846$; OR=7); teste de "Whiff" positivo $(p=0,0846$; e $\mathrm{OR}=7$ ). As variávies relacionadas ao aspecto clínico do colo, que pudessem sugerir infecção por $C$. trachomatis, não foram significativas neste estudo. 
Tabela 22. Associação univariada de DST com variáveis de comportamento e clínicas de 105 mulheres. Tremembé, 2003.

\begin{tabular}{|c|c|c|c|c|c|c|c|c|c|c|c|}
\hline \multirow{3}{*}{ VARIÁVEL } & \multicolumn{6}{|c|}{ DST } & \multirow{3}{*}{ ODDS } & \multirow{3}{*}{$\begin{array}{l}\text { Erro } \\
\text { padrão }\end{array}$} & \multirow{3}{*}{ p valor } & \multirow{2}{*}{\multicolumn{2}{|c|}{ IC $95 \%$}} \\
\hline & \multicolumn{2}{|c|}{ SIM } & \multicolumn{2}{|c|}{ NĀO } & \multicolumn{2}{|c|}{ TOTAL } & & & & & \\
\hline & $n=5$ & $\%$ & $n=100$ & $\%$ & $n=105$ & $\%$ & & & & $\mathrm{LI}$ & LS \\
\hline \multicolumn{12}{|c|}{ Mais de um parceiro nos últimos 3 meses } \\
\hline Sim & 2 & 40 & 12 & 12 & 14 & 13 & 4,8891 & 0,9633 & 0,0995 & 0,7400 & 32,3024 \\
\hline Não & 3 & 60 & 88 & 88 & 91 & 87 & 1,0000 & & & & \\
\hline Novo parceiro nos últimos 3 meses & 2 & 40 & 2 & 2 & 4 & 4 & & & & & \\
\hline $\begin{array}{l}\text { Sim } \\
\text { Não }\end{array}$ & 3 & 60 & 98 & 98 & 101 & 96 & $\begin{array}{c}32,6698 \\
1,0000\end{array}$ & 1,1591 & 0,0026 & 3,3689 & 316,8121 \\
\hline \multicolumn{12}{|l|}{ Cor da leucorréia } \\
\hline Amarela ou outra & 3 & 60 & 23 & 23 & 26 & 25 & 5,0218 & 0,9433 & 0,0871 & 0,7905 & 31,9007 \\
\hline Branca & 2 & 40 & 77 & 77 & 79 & 75 & 1,0000 & & & & \\
\hline \multicolumn{12}{|l|}{ Medida do pH } \\
\hline$>4,5$ & 4 & 80 & 36 & 36 & 40 & 38 & 7,1111 & 1,1373 & 0,0846 & 0,7654 & 66,0700 \\
\hline$<4,5$ & 1 & 20 & 64 & 64 & 65 & 62 & 1,0000 & & & & \\
\hline \multicolumn{12}{|l|}{ Teste de "Whiff" } \\
\hline Positivo & 4 & 80 & 36 & 36 & 40 & 38 & 7,1111 & 0,5678 & 0,0846 & 2,3368 & 21,6397 \\
\hline Negativo & 1 & 20 & 64 & 64 & 65 & 62 & 1,0000 & & & & \\
\hline \multicolumn{12}{|l|}{ Escore de Risco do Ministério da Saúde } \\
\hline 2 & 2 & 40 & 3 & 3 & 5 & 95 & 21,5556 & 1,0849 & 0,0046 & 2,5709 & 180,7312 \\
\hline o a 1 & 3 & 60 & 97 & 97 & 100 & 5 & 1,0000 & & & & \\
\hline
\end{tabular}

$\mathrm{IC}=$ intervalo de confiança 
A partir desses dados, analisou-se quais as variáveis que poderiam representar um ganho de qualidade no diagnóstico, especificamente, para cervicites por $C$. trachomatis, uma vez que, não houve nenhum caso de gonorréia.

Verificou-se que a aplicação dos escores de risco originalmente propostos resulta em sensibilidade, especificidade e valor preditivo positivo de, respectivamente, $66,7 \% ; 97,1 \%$ e $40,0 \%$. O escore de risco igual ou superior a dois, referendado pelo Ministério da Saúde, foi estatisticamente significativo $(p=0,0046)$, indicando risco 21 vezes maior para DST (Tabela 23).

No caso de infecção por C. trachomatis, a variável cor "amarela ou outra" do corrimento, apresentou uma sensibilidade de $66,7 \%$, especificidade de $79,4 \%$ e valor preditivo positivo de $8,63 \%$. O teste de "Whiff" e a medida de $\mathrm{pH}$ apresentaram percentuais próximos de sensibilidade, especificidade e valor preditivo positivo, aos da cor do corrimento.

Tabela 23. Sensibilidade (S), especificidade (E) e valor preditivo positivo (VPP) dos escores de risco originalmente propostos pelo Ministério da Saúde (MS) e dos escores sugeridos no estudo. Tremembé, 2003.

\begin{tabular}{lccc}
\hline \multicolumn{1}{c}{ Escores } & $\begin{array}{c}\text { S\% } \\
(I C 95 \%)\end{array}$ & $\begin{array}{c}E \% \\
(I C 95 \%)\end{array}$ & $\begin{array}{c}\text { VPP\% } \\
(I C 95 \%)\end{array}$ \\
\hline Escore do MS $\geq 2$ & 66,7 & 97,1 & 40,0 \\
Medida de pH $>$ 4,5 & $(57,6-75,7)$ & $(93,8-100,0)$ & $(30,6-49,4)$ \\
& 66,7 & 62,7 & 5,0 \\
Teste de "Whiff" positivo & $(57,6-75,7)$ & $(53,5-72,0)$ & $(0,8-9,2)$ \\
& 66,7 & 74,5 & 7,4 \\
Corrimento "amarelo ou outro" & $(57,6-75,7)$ & $(66,0-82,9)$ & $(2,4-16,2)$ \\
& 66,7 & 79,4 & 8,6 \\
\hline
\end{tabular}

IC = intervalo de confiança 
$\mathrm{Na}$ tabela, 24 fez-se uma associação dos fatores de risco comportamentais já estabelecidos pelo Ministério da Saúde, com os fatores identificados no estudo que tiveram melhor desempenho nos testes estatísticos. A finalidade foi saber se haveria algum acréscimo na sensibilidade, especificidade e valor preditivo positivo, e assim, indicar o modelo para ser aplicado no município de Tremembé.

Verificou-se que não houve acréscimo significativo em nenhum dos quatro modelos propostos, em relação à especificidade e valor preditivo positivo. No caso da cor da leucorréia, a sensibilidade aumentou para $100,0 \%$, não alterando a especificidade e nem o valor preditivo positivo, porém foi o melhor desempenho observado dentre os demais.

Tabela 24. Sensibilidade (S), especificidade (E) e valor preditivo positivo (VPP) dos escores de risco originalmente propostos pelo Ministério da Saúde (MS) associados aos escores sugeridos no estudo. Tremembé, 2003.

\begin{tabular}{|l|c|c|c|}
\hline \multicolumn{1}{|c|}{ Escores } & $\begin{array}{c}\text { S \% } \\
(I C 95 \%)\end{array}$ & $\begin{array}{c}E \% \\
(I C ~ 95 \%)\end{array}$ & $\begin{array}{c}\text { VPP\% } \\
(I C 95 \%)\end{array}$ \\
\hline Escore do MS $\geq 2$ ou Medida de $\mathrm{pH}>4,5$ & $\begin{array}{c}66,7 \\
(57,6-75,7)\end{array}$ & $\begin{array}{c}68,6 \\
(64,7-72,8)\end{array}$ & $\begin{array}{c}5,8 \\
(2,0-13,6)\end{array}$ \\
\hline $\begin{array}{l}\text { Escore do MS } \geq 2 \text { ou Teste de "Whiff" } \\
\text { positivo }\end{array}$ & $\begin{array}{c}66,7 \\
(57,6-75,7)\end{array}$ & $\begin{array}{c}65,7 \\
(56,8-74,6)\end{array}$ & $\begin{array}{c}5,4 \\
(1,6-12,4)\end{array}$ \\
\hline $\begin{array}{l}\text { Escore do MS } \geq 2 \text { ou corrimento "amarelo } \\
\text { ou outro" }\end{array}$ & 100,0 & $\begin{array}{c}79,4 \\
(71,5-87,2)\end{array}$ & $\begin{array}{c}12,5 \\
(7,3-25,7)\end{array}$ \\
\hline $\begin{array}{l}\text { Escore do MS } \geq 2 \text { ou escore de } \\
\text { Papanicolaou (L 2+; MEV e/ou CER) }\end{array}$ & $\begin{array}{c}66,7 \\
75,4\end{array}$ & $\begin{array}{c}7,4 \\
(67,6-75,7)\end{array}$ \\
\hline
\end{tabular}

IC = intervalo de confiança

L 2+ =leucócitos (duas cruzes)

$\mathrm{MEV}=$ metaplasia escamosa com vacúolos sem inclusão

CER=células endocervicais reativas 


\subsubsection{Avaliação do perfil sociodemográfico, comportamental e clinico-obstétrico como fator de risco para mulheres com vaginose bacteriana ou candidiase}

Do mesmo modo que para as DST, avaliou-se também os perfis demográficos, comportamentais e gineco-obstéricos do grupo de 13 $(100,0 \%)$ mulheres com quadros exclusivamente atribuídos à vaginose bacteriana e $13(100,0 \%)$ de candidiase, comparados com o restante da população que foi considerada negativa para ambas condiçōes (tabela 25)

A distribuição dos casos por faixa etária foi maior dos 35 a 44 anos porém essa distribuição não demonstrou ser estatisticamente significativa $(p>0,30)$. A maioria das mulheres era casada e $69,2 \%$ das pacientes com candidiase cursaram o $2^{\circ}$ grau, diferença significativa comparada as demais mulheres $(p<0,0166)$. No grupo das mulheres com vaginose, o ensino fundamental de $1^{\mathrm{a}}$ a $8^{\mathrm{a}}$ série teve 0 maior número de representantes. $O$ equivalente a $46,1 \%$ das mulheres com vaginose bacteriana tinham renda familiar de até dois salários mínimos, enquanto $69,2 \%$ de pesquisadas com candidiase tinham renda de 3 a 6 salários, sem significância estatística.

As variáveis do início de atividade sexual, ocorrendo em maiores de 17 anos pela maioria do grupo das mulheres com candidiase em menores de 17 anos, pelo grupo de mulheres com vaginose bacteriana, não tiveram significância estatística. $O$ número de partos foi maior para o grupo de mulheres com vaginose bacteriana $(61,5 \% p=0,0868)$. $O$ nenhum uso de método contraceptivo ou não uso de preservativo masculino, foi mais frequente entre as mulheres com vaginose bacteriana $(92,3 \% p=0,0474) .0$ parto prematuro foi igualmente referido por $23,1 \%$ dos dois grupos e também cerca de $23,1 \%$ de mulheres com vaginose bacteriana, referiu DST anterior e, $30,8 \%$, referiu aborto, porém, sem significância estatística. 
A freqüência do uso de ducha elou absorvente intimo, tiveram distribuição similar ao restante da população, sem significância estatística, bem como as demais variáveis de comportamento e clínicas.

Entre as pacientes com candidiase, foram significativas as variáveis da leucorréia com aspecto não mucoso $(p=0,08 ; O R=4) ; p H<4,5$ $(p=0,0006 ; O R=155)$ e teste de "Whiff" negativo $(p=0,0009 ; O R=71)$.

Tabela 25. Associação univariada de vaginose bacteriana e candidiase com variáveis de comportamento e clínicas de 105 mulheres. Tremembé, 2003.

\begin{tabular}{|c|c|c|c|c|}
\hline \multirow{2}{*}{ Caracteristicas } & \multicolumn{2}{|c|}{ Candidiase $(n=13)$} & \multicolumn{2}{|c|}{$V B^{*} V B(n=13)$} \\
\hline & $\mathbf{p}$ & ODSS & $\mathbf{p}$ & ODSS \\
\hline \multicolumn{5}{|l|}{ Escolaridade } \\
\hline até $8^{\mathrm{a}}$ série & 0,0166 & 1,0000 & 1,0000 & 1,0000 \\
\hline $2^{\circ}$ grau ou mais & & 8,3333 & & 1,0000 \\
\hline \multicolumn{5}{|l|}{ Paridade } \\
\hline 2 ou mals filhos & 1,0000 & 1,0000 & 0,0868 & 4,3750 \\
\hline 0 a 1 filho & & 1,0000 & 1,0000 & \\
\hline \multicolumn{5}{|l|}{ Método contraceptivo } \\
\hline preservativo masculino & 1,0000 & 1,0000 & & \\
\hline outro & & 1,0000 & 0,0474 & 10,8321 \\
\hline \multicolumn{5}{|l|}{ Aspecto da leucorréia } \\
\hline não mucoso & 0,0888 & 4,0500 & 1,0000 & 1,0000 \\
\hline mucoso & & 1,0000 & & 1,0000 \\
\hline \multicolumn{5}{|l|}{ Medida de $\mathrm{pH}$} \\
\hline$<4,5$ & 0,0006 & 155,9610 & & 1,0000 \\
\hline$>4,5$ & & 1,0000 & 0,001 & 129,9800 \\
\hline \multicolumn{5}{|l|}{ Teste de "Whiff" } \\
\hline positivo & & 1,0000 & & 1,0000 \\
\hline negativo & 0,0009 & 71,4966 & 1,0000 & 1,0000 \\
\hline
\end{tabular}

*VB= vaginose bacteriana 


\section{DISCUSSÃO}

A abordagem sindrômica trouxe, na década de 90 , uma nova proposta para o tratamento de DST, principalmente nos paises em desenvolvimento ou de poucos recursos, visto que os testes laboratoriais para muitos desses agravos demandam infra-estrutura sofisticada, pessoal especializado e, conseqüentemente, aumento do custo.

No entanto, a visão promissora de se ter à disposição metodologia simples, barata e custo-efetiva mostrou, ao longo do tempo, dificuldades no emprego satisfatório dos algoritmos. A síndrome do corrimento vaginal, principalmente no que concerne ao diagnóstico das cervicites por $C$. trachomatis e gonorréia, foi a que demonstrou, segundo vários críticos, 0 pior resultado.

Assim, nos últimos anos, em diversos trabalhos tem-se buscado novos parâmetros para garantir o desempenho da abordagem sindrômica nas mulheres com corrimento vaginal, dada a importância dessas DST no contexto da saúde reprodutiva da mulher e a relevância de se obter um diagnóstico fidedigno e tratamento eficaz no âmbito da saúde pública.

Por outro lado, muitos estudos também demonstraram que a abordagem sindrômica mostra uma melhor relação custo-benefício a longo prazo, uma vez que as complicações advindas de tratamentos inadequados ou da falta de tratamento podem resultar em custos elevadíssimos para 0 sistema de saúde e, nesse caso, o manejo sindrômico funcionaria como uma ação preventiva de baixo custo relativo (AMARAL 1998, BRABIN 2000, BENZAKEN e col. 2001, CATCHPOLE 2001, DADIAN 1996, FONK 2000, HAWKES 1999, MAYAUD e col. 1998, MOHERDAUI e col. 1998). 
A proposição do presente estudo também buscou investigar novas alternativas para subsidiar um melhor aproveitamento da abordagem sindrômica, além de conhecer o perfil epidemiológico das mulheres portadoras de corrimento vaginal de uma localidade com menos de 100.000 habitantes, como é o caso do município de Tremembé.

De acordo com os dados demográficos da tabela 1 , cerca de $57,2 \%$ das mulheres que buscaram assistência no Centro de Saúde de Tremembé tinham, até 34 anos. A FUNDAÇÃO PERSEU ABRAMO (2001), num amplo estudo sociodemográfico sobre a mulher brasileira, revala, percentual de 53,0\%, na mesma faixa etária. Esse percentual é semelhante também ao descrito em vários estudos, tanto, por autores que pesquisaram leucorréia, quanto, por aqueles que avaliaram exames colpocitológicos em ambulatórios de ginecologia (RODRIGUEZ e col. 2000, DI BARTOLOMEO e col. 2002, AVILÉS e col. 2001, MOTTA e col. 2001).

Verifica-se, ainda, que a distribuição de mulheres quanto ao estado marital, também foi concordante com dados divulgados pela FUNDAÇÃO PERSEU ABRAMO (2001), que revela uma taxa de $57,0 \%$ de mulheres casadas, em nivel nacional. $O$ maior extrato das entrevistadas $(37,1 \%)$, declarou ter nivel de escolaridade equivalente ao $2^{\circ} \mathrm{grau}$, o que diferencia este grupo do restante da população brasileira, mesmo considerando que, no protocolo da pesquisa, esse item não discriminava se o curso era completo ou incompleto $(p=0,001$ para pacientes com candidiase). A região sul do Brasil, considerada a de maior nivel de escolaridade, tem $12,1 \%$ de mulheres que cursaram de 8 a 10 anos de escola (IBGE 2002). A mesma fonte acrescenta que municípios com menos de 100.000 habitantes tendem a ter menores taxas de nivel de escolaridade. Dessa forma, a população estudada evidencia elevado padrão escolar, o que teoricamente seria um ponto favorável para melhor compreensão e assimilação de ações educativas no campo das DST. 
Cerca de $52,4 \%$ das mulheres trabalha e a renda familiar compreende até dois salários mínimos. A média nacional de mulheres com participação no mercado de trabalho é de $32,9 \%$, em municípios de 20.000 a 100.000 habitantes (FUNDAÇÃO SEADE 2002, IBGE 2002). Em relação ao nivel salarial, parece retratar o panorama nacional com mulheres com rendimento médio de 1,4 salários mínimos.

Segundo a FUNDAÇÃO SEADE (2002), a dificuldade de inserção no mercado de trabalho tem levado cada vez mais mulheres a procurar obter maior nivel de escolaridade, como forma de assegurar a conquista de novas ocupações, porém isso não significa melhora no salário, nem tampouco da conquista de empregos diferenciados, o que se confirma quando observamos, no presente estudo, que a maioria das mulheres trabalhavam como empregadas domésticas. Em relação aos seus parceiros, a ocupação de operário da construção civil foi o mais referido entre as pesquisadas, contribuindo, assim, presumidamente, à renda familiar baixa.

Em relação às características gineco-obstétricas (tabela 2), as mulheres reportaram ter em média $2 \pm 2$ filhos $(p=0,0868$ para mulheres com vaginose), com $34,3 \%$ referindo ter de 2 a 3 filhos nascidos vivos. No entanto, RADO e col. (2001), não confirmaram significância estatística entre o número de filhos superior a dois e a vaginose bacteriana.

Por outro lado, OLINTO E GALVÃO (1999) citam média de 2,4 filhos em estudo sobre as características reprodutivas de mulheres da cidade de Pelotas, e o IBGE (2002) afirma que, a taxa de fecundidade do Brasil é de 2,38 filhos por mulher. Todas as taxas encontradas são semelhantes e garantem a reposição das gerações, sob o ponto de vista demográfico.

Mais da metade das mulheres teve seus filhos através do parto normal, porém, somando as mulheres que tiveram parto normal elou pelo 
menos uma cesariana, verifica-se um percentual de $42,7 \%$, que, embora alto, ainda é pouco menor do que os percentuais do Estado de São Paulo, os quais chegam a $48,2 \%$ (FUNDAÇÃO SEADE 2002). Essa taxa está muito acima do recomendado, até para casos de gravidez de risco, que eleva a morbimortalidade materna. $O$ mesmo texto descreve que o motivo dessas taxas serem altas, está aliado ao fato de que esse procedimento é o meio mais freqüente para a realização da esterilização, o que também é confirmado por VIEIRA e col. 2001.

Mulheres com história de aborto constituíram 20,9\% das entrevistadas, revelando percentual pouco inferior ao referido pelo SEADE (2002), que é de $27,7 \%$. A questão do aborto é relevante pela associação com vaginose bacteriana e outras DST, como já descrito anteriormente, porém não se constatou significância estatística, neste trabalho.

A cauterização do colo uterino foi pesquisada no sentido de procurar mulheres com histórico de processos inflamatórios acentuados que requerem esse procedimento, e eventualmente remeter a possiveis casos de $N$. gonorrhoeae ou $C$. trachomatis. Verificou-se que os $37,1 \%$ haviam se submetido à cauterização pelo menos uma vez na vida, porém, na maioria das vezes num periodo superior a seis meses da data da coleta dos dados, e os quatro casos recentes, estavam relacionados com o tratamento de HPV, como preconiza o Programa Viva Mulher para esses casos (INCA 2002).

Em relação ao uso de métodos contraceptivos, os mais freqüentes foram o contraceptivo oral, preservativo masculino e laqueadura tubária. Segundo VIEIRA e col. (2001), o uso de pilula no Estado de São Paulo é referido sob um percentual de $17,0 \%$ e, no Brasil, em 15,8\%. A laqueadura é citada no mesmo trabalho, tendo percentual de $23,6 \%$ e $27,3 \%$, em São Paulo e no Brasil, respectivamente; e ainda, o uso de preservativo masculino nas mesmas populações é descrito com o percentual de $6,6 \%$ e $4,3 \%$. 
OLINTO E GALVÃO (1999) também encontraram percentuais semelhantes: $7,5 \%$. Assim, chama a atenção a diferença do uso de preservativo masculino pelas usuárias do serviço de saúde de Tremembé, que foi citado por $18,1 \%$ das mulheres. Essa diferença pode estar relacionada ao nivel de escolaridade das pacientes entrevistadas do presente estudo, fato esse, constatado também no trabalho de JIMÉNEZ e col. (2001), que descreveu o uso de preservativo masculino por $28,0 \%$ mulheres adultas de médio-alto nível sócio-econômico. Verificou-se significância estatística entre pacientes com candidíase que cursaram $2^{\circ}$ grau, as quais, faziam uso do preservativo masculino como método contraceptivo, ao contrário das pacientes portadoras de vaginose que, em maior número, não eram adeptas a seu uso $(p=0,04)$ e tinham menor nivel de escolaridade.

Na tabela 3 constatou-se que o ínicio da atividade sexual ocorreu, em média, aos $18 \pm 3$ anos, demonstrando ser algo superior àquela referida pela pesquisa nacional da FUNDAÇÃO PERSEU ABRAMO (2001) como de 15 a 19 anos, porém semelhante à descrita por CANTO-DE-CETINA e col. (2002), que foi aos $17,6 \pm 2$ anos, num estudo de prevalência de vaginose bacteriana por mulheres com vaginose bacteriana e de $18 \pm 1,8$ anos, para aquelas que não apresentavam o quadro bacteriano.

O início tardio da atividade sexual pode ser entendido como um fator protetor para DST, uma vez que a atividade sexual precoce caracteriza um dos principais fatores de risco para esses agravos, como já bem referendado por diversos autores, porém sem significância estatística no presente estudo (CCD 2000, MINISTÉRIO DA SAÚDE 1998b 1999)

A frequeência do uso de preservativo masculino, que é um importante indicador da prática de medidas preventivas individuais contra DST, foi citada como de uso constante apenas por aquelas mulheres que não queriam a gravidez, demonstrando a necessidade de maior conscientização dessa população quanto aos perigos das DST. Esse fato 
também foi observado por FERNANDES e col. (2000), que, abordando o conhecimento de DST por mulheres atendidas na rede básica de saúde, revelaram que apenas $2,4 \%$ de mulheres declaram o uso do preservativo masculino para prevenir DST. Os motivos do uso, segundo os autores, pela ordem de freqüência, são: gravidez, laqueadura, parceiro fixo e como método de contracepção.

O uso de ducha e/ou absorvente intimo tem sido relacionado com a promoção de alteração da microbiota normal lactobacilar, corroborando com a instalação de processos patogênicos pela modificação bioquímica do meio e, ainda, pela ducha, facilita-se a ascensão desses agentes ao trato genital superior. Os dados desta pesquisa apontaram o uso de ducha e/ou absorvente íntimo por $15,2 \%$ das entrevistadas e apenas duas relataram o uso constante, diferindo do percentual referido por SCHWEBKE e RICHEY (1999), que descreveram percentual de $36,7 \%$ para o uso de ducha e $63,3 \%$ para o uso de absorvente intimo, sendo que mais da metade daquelas mulheres tinha essa conduta com freqüência superior a duas vezes ao mês, nos dois casos.

O comportamento sexual, de acordo com todos os autores que referendam este trabalho, sem dúvida nenhuma, é o fator de maior expressão na aquisição ou não de uma DST. Portanto, para delinear o perfil de risco da população estudada conforme o fluoxograma proposto pelo Ministério da Saúde, perguntou-se sobre a atividade sexual com parceiro fixo; com mais de um; ou com novo parceiro nos últimos três meses. A maioria das mulheres referiu parceria fixa; $10,5 \%(p=0,0995)$ relatram mais de uma parceria sexual, nos últimos três meses; e 2,8\% ( $p=0,0026)$, um novo parceiro no mesmo período de tempo. STORCK e col. (2001), numa pesquisa de DST entre donas de casa, registraram um percentual de $5,8 \%$ de mulheres que declararam ter mais de dois parceiros nos últimos dois anos. 
No entanto, esses dados diferem dos percentuais encontrados por FONCK e col. (2000) em população de grávidas e não-grávidas da África, cujos percentuais foram de $14,0 \%$ para mais de um parceiro nos últimos três meses, e de 17,0\% para um novo parceiro, no mesmo periodo. Em Gâmbia, a pesquisa de WALRAVEN e col. (2001) com pacientes de uma zona rural refere $61,8 \%$ de $18,0 \% \%$, respectivamente, para esses comportamentos; porém, relatam que a poligamia é freqüente naquele país. Contrastando com esses dados, ARAÚJO e col. (2002), que pesquisaram pacientes de uma unidade de referência para DST, verificaram que apenas $7,7 \%$ de mulheres declararam ter mais de um parceiro, concluindo que mulheres de alto risco não estão procurando tratamento nessas unidades específicas.

Esse dado leva à inferência da importância da detecção de DST em clínicas de planejamento familiar ou outras que possam atender as mulheres com corrimento pois, dentre elas, certamente estarão as de risco, o que se confirmou quando duas pacientes desta pesquisa, referiram sorologia positiva para HIV.

Por outro lado, isso demonstra a necessidade de maior divulgação dos serviços especializados de DST, mediante articulaçōes com organizações não-governamentais e os centros especializados, para promover 0 acesso da população de maior risco aos serviços de referência.

Em relação ao histórico de DST anterior ou de outra condição que estivesse relacionada a esse grupo de doenças (tabela 4), a maior freqüência $(12,4 \%)$ foi observada em mulheres com relato de parto prematuro. Trata-se de um dado importante, visto que esse tipo de parto é referido como uma das principais conseqüências da vaginose bacteriana na gravidez, no entanto, não foi significativo neste trabalho. De acordo com CANTO-DE-CETINA e col. (2000), houve diferença significativa na declaração de ocorrência de parto prematuro em mulheres com e sem vaginose bacteriana da ordem de $14,6 \%$ e $3,1 \%$, respectivamente. RADO e 
col. (2001), citaram ocorrência de $5,2 \%$ de partos prematuros, num estudo sobre vaginose bacteriana em gestantes. Frisaram, porém, não haver diferença estatisticamente significativa entre as gestantes com vaginose bacteriana que tiveram parto prematuro $(4,5 \%)$ e aquelas sem essa condição, que também tiveram um parto pré-termo. Um percentual de $9,9 \%$ de prematuridade em mulheres não esterilizadas também foi encontrado por OLINTO E GALVÄO (1999), sem a explicação, entretanto, da correlação entre ambas as condiçōes.

Quanto às queixas de parceiros com DST prévia, ou sintomatologia referida na região genital, foi declarado um caso de corrimento uretral, um de herpes e um de gonorréia, porém todos de ocorrência superior a um ano, segundo as pacientes na pesquisa. Apenas um portador de condiloma foi referido por uma das pacientes, HIV positiva, cujo parceiro também era sororeagente. As outras queixas relacionadas foram ardência, prurido e irritação da pele do pênis, o que poderia estar relacionado com um quadro de candidiase da paciente, como sugerem CHECA e SÁNCHEZ (2001), no entanto, não houve associação estatística significativa daquela variável, com as pacientes que apresentaram cultura positiva para Candida albicans.

Como era de se esperar, mais de $59,5 \%$ das consultas foi realizada devido à presença de corrimento vaginal, no entanto, o restante da população estudada procurou o serviço para realização do exame preventivo ou por causa de ambos (tabela 5).

Esta constatação parece demandar uma ação mais ampla, de abrangência política, pois mostra o desencontro do Programa de DST/AIDS e do Programa de Prevenção do Câncer do Colo Uterino. Essa divergência evidencia o caráter paralelo que ambos se inserem no contexto da saúde pública, necessitando a promoção de linhas estratégicas, para que juntos alcancem suas metas fundamentais que são prevenir e tratar, reduzindo 
assim, o impacto que esses agravos têm na população, porém sem duplicar recursos desnecessários, como se observa atualmente.

Desse modo, a mulher que pouco sabe sobre o que é realmente um corrimento e como deve ser tratado, achando muitas vezes tratar-se de processo "fisiológico", raramente relaciona como uma possível DST e, quando percebe 0 corrimento, procura realizar 0 exame preventivo (STORCK e col. 2001, FERNANDES e col. 2000).

Por outro lado, há o médico que atende pacientes no pré-natal e na gineco-obstetricia, o qual geralmente não tem nem treinamento e nem experiência em DST, o que o conduz a tornar o resultado do teste de Papanicolaou seu principal instrumento de apoio ao tratamento (AMARAL 1998).

O Programa de Prevenção do Câncer tem boa aceitabilidade entre as mulheres e realmente pode ser aproveitado, para que, nos locais onde se desenvolve, também seja promovida a abordagem sindrômica para corrimentos vaginais. $O$ alcance do Programa também pode ser observado nesta pesquisa, em que $95,2 \%$ das mulheres atendidas relataram já ter realizado um exame preventivo anterior. Esse percentual é superior àquele referido pelo INCA (2002) para o Estado de São Paulo, onde são apontados percentuais de $34,8 \%$ e $46,8 \%$ das mulheres com menos de 35 anos e entre de 35 a 49 anos, respectivamente, as quais nunca fizeram um exame preventivo (tabela 6 ).

De acordo com o INCA (2002), no passado, as ações dirigidas à detecção precoce do câncer do colo do útero, no Brasil, caracterizaram-se, na maioria das vezes, por estratégias isoladas e pontuais, sem o impacto necessário para o controle da doença. A partir da implantação do Programa Viva Mulher, diversas metas e estratégias visaram estabelecer: ações de gerenciamento, de comunicação social, padronização de normas técnicas, 
preparação quantitativa e qualitativa da rede de serviços, estabelecimento de referências e contra-referências, incorporação de novas tecnologias de tratamento, monitoramento de ações e financiamento do sistema de saúde.

As principais estratégias, no entanto, destacam: a disponibilização do exame citopatológico de Papanicolaou para as mulheres entre 25 e 59 anos de idade, 0 tratamento adequado da doença e de suas lesões precursoras em todos os casos e monitoramento da qualidade do atendimento à mulher, nas suas diferentes etapas. Confirmando a abrangência do Programa em nivel nacional, o INCA (2002) ressalta que, entre agosto de 1998 e julho de 2002, foram realizados 37.446 .158 exames citopatológicos 191.453 exames anatomopatológicos do colo do útero e 76.943 cirurgias de alta frequêencia.

Assim, parece claro, pelos dados expostos, que a articulação política entre o Programa DSTIAIDS e o de Prevenção do Câncer de Colo uterino, seria extremamente oportuno, visto que, ambos preconizam metodologias simples, como principal estratégia de ação, beneficiando desta forma, o enorme contingente de mulheres que são atendidas pelo Programa de Prevenção do Câncer de Colo Uterino, aproveitando toda uma estrutura técnica e política bem organizada e operante, já existente.

Por outro lado, a abordagem sindrômica, tal como a OMS concebeu inicialmente, foi sofrendo adaptações ao longo do tempo, e várias estratégias como a adição de fatores de risco comportamental ou parâmetros clínicos diversos, foram adotadas em diversas localidades, com o fim de melhorar o desempenho da metodologia BRABIN (2000), HAWKES e col. (1999).

No entanto, a questão da sensibilidade e do valor preditivo positivo continua sendo questionada. Isso se deve a uma série de fatores, tais como: a prevalência da doença, o que influencia no resultado dos testes de 
sensibilidade (GRIMES e SCHULZ 2002); os casos assintomáticos de C. trachomatis e gonorréia, muito freqüentes na população feminina e das características inespecificas do colo uterino ao exame clínico, cujas alterações podem mimetizar cervicites de outras etiologias (VAN DAM 1995, MAYAUD e col. 1998).

Mais recentemente, foram incluidos testes de laboratório simples para melhorar o diagnóstico, porém, para os casos de cervicites, os fatores de risco comportamental são aqueles que podem realmente, aumentar a sensibilidade e o valor preditivo positivo, segundo MOHERDAUI e col. (1998).

A proposta deste estudo foi empregar a abordagem sindrômica, usando-se os critérios clínicos e escores de risco comportamental recomendados pelo Ministério da Saúde, acrescidos dos testes simples obtidos no consultório, como a medida de $\mathrm{pH}$ e o teste de "Whiff", que embora também preconize seu uso, não é uma prática constante nos ambulatórios de ginecologia da rede pública.

Assim, após a avaliação clínica, o médico instituiu o tratamento, aconselhou a paciente e marcou o seu retorno para a conferência dos exames laboratoriais microbiológicos e do teste de Papanicolaou.

De acordo com WARD e col. (2001), 26,2\% das pacientes de uma clínica de planejamento familiar apresentaram colo friável, percentual superior ao encontrado neste trabalho, que foi de $14,3 \%$. ORTAYLI e col. (2001) referem $4,0 \%$ de pacientes com o colo friável, numa população de mulheres com DST, e $2,8 \%$ de mulheres sem DST, com o mesmo quadro clínico (tabela 7). 
Em relação ao aspecto da leucorréia, RADO e col. (2001) descreveram secreção vaginal "leitosa e homogênea" na maioria das pacientes estudadas $(73,8 \%)$. Vale destacar que a maioria dos trabalhos que pesquisou secreçőes vaginais de mulheres com vaginose bacteriana mostrou forte associação da leucorréia "cinza e homogênea" com esse quadro. Assim, NAVARRETE e col. (2000) referem $61,3 \%$ de pacientes com essa característica no corrimento; CANTO-DE-CETINA e col. (2002), referendam 33,3\%; RODRIGUEZ e col. (2000) citam $52,5 \%$ de pacientes. Esse achado não foi evidenciado no presente estudo, posto que apenas $6,7 \%$ do total de pacientes apresentaram corrimento acinzentado (tabela 8), embora tenha sido confirmado o quadro de vaginose bacteriana em $17,1 \%$ mulheres (tabela 17). No entanto, a análise univariada, demonstrou que a cor da leucorréia, interpretada como "amarela ou outra", foi significativa para as pacientes com DST $(p=0,0871)$.

O teste de "Whiff" foi positivo em $23,8 \%$ das pacientes (tabela 9), e $17,1 \%$ das mulheres estudadas apresentaram vaginose bacteriana e esse dado, surpreendentemente, não foi significativo entre as mulheres com esse quadro, e sim, para as mulheres com DST ( $p=0,001)$. RADO e col. (2001) citaram $2,9 \%$ pacientes sem vaginose bacteriana, mas, com teste de aminas positivo. O pH maior ou igual a 4,5 foi referido por NAVARRETE e col. (2000) em $71,2 \%$ de mulheres sem vaginose bacteriana, e em $96,0 \%$ com vaginose bacteriana, enquanto que no presente estudo, encontrou-se uma medida de $\mathrm{pH}$ superior a 4,5 em $38,1 \%$ das pacientes. Esses dados contrastantes são atribuídos, segundo HALBE (2000), NAVARRETE e col. (2000), SOBEL (1997), ROSSI e col. (2000) e POZO e col. (2000) a fatores que alteram o teste de "Whiff" e $\circ \mathrm{pH}$, os quais serão apresentados posteriormente, na discussão sobre a vaginose bacteriana. ORTAYLI e col (2000), referem a ocorrência de vaginose bacteriana em pacientes com DST, com uma associação significativa $(p<0,05)$. 
Na mesma tabela, verifica-se que o teste de "Schiller" foi positivo em $25,7 \%$ da população, no entanto, a descrição clínica de colo com ectrópio totalizou $33,3 \%$ de casos. SINGH e col. (2001) avaliaram o uso do teste de "Schiller" na detecção de displasias cervicais e obtiveram taxa de $58,8 \%$ de positividade no teste, com $40 \%$, atribuídos a casos de ectrópio.

Os resultados da tabela 10 mostram que o clínico fechou seu diagnóstico em $21,9 \%$ de vaginose bacteriana elou tricomoníase associada ou não à cervicite; $10,5 \%$ de candidíase associada ou não à cervicite, e $5,7 \%$ de cervicites por outras causas. O clínico diagnosticou $4,8 \%$ casos de infecção por C. trachomatís elou gonoréia, e os demais $13,3 \%$, infeccōes mistas.

Em relação ao estudo de MOHERDAUl e col. (1998), verificou-se uma discrepância quanto às infecções mistas, que é apontada com um percentual de $5 \%$. Essa diferença pode ser atribuida ao local onde foi conduzido o estudo, pois se tratava de ambulatório de referência de DST, onde presumidamente, os médicos têm maior experiência em casos de DST.

$O$ tratamento dessas mulheres e de seus parceiros (tabela 11) foi prescrito conforme o esquema recomendado pelo MINISTÉRIO DA SAÚDE (1999), ressaltando-se, que em alguns casos, o clínico optou por outro esquema, principalmente quando o quadro de infecção por $C$. trachomatis ou gonorréia foi atribuído apenas a escores de risco. Esse comportamento já foi relatado por BOSU (1999) quanto à insegurança que os clínicos têm em realizar diagnóstico, sem base clínica, e em prescrever esquema antimicrobiano devido a esse diagnóstico. $O$ clínico também fez sua opção pessoal ao tratar parceiros de pacientes com vaginose bacteriana e candidiase.

Outro dado importante foi que nenhuma paciente relatou fazer auto-medicação ou procurar outro tipo de atendimento, que não o médico, contrastando com a citação de ARAÚJO e col. (2002) que descrevem 
percentual de $78,6 \%$ de pacientes com alguma DST, os quais, tomaram antimicrobianos por conta própria, na tentativa de curar a doença. Infere-se, assim, que as pacientes da cidade de Tremembé têm confiança em seu médico e sempre o procuram em caso de doença, sendo esse fato também observado por FERNANDES e col. (2000) em $85,0 \%$ de mulheres argüidas sobre conduta de DST.

Nas tabelas 12, 13 e 14, são apresentados os resultados laboratoriais dos exames microbiológicos realizados. Destaca-se a total concordância entre os achados no exame direto "a fresco" e no exame com a coloração de Gram. Em relação à pesquisa de fungos, os dados referentes à sensibilidade de $83,3 \%$ e $100,0 \%$ de especificidade (tabela 20) contrapõem-se à maioria dos autores, que citam baixa sensibilidade do exame direto "a fresco", em torno de 50 a $70 \%$, justificando que há espécies de leveduras como C. glabrata, que não produzem pseudo-hifas, dificultando assim seu reconhecimento (CHECA e SANCHEZ 2001, DAVIES e PATRUNO 2000). Um fator para explicação dos dados ora apresentados seria a subjetividade intrínseca do leitor, pois ambos os exames foram lidos pelo mesmo biologista.

Por outro lado, a diferença de resultados dos exames bacterioscópicos e cultura de fungos, são também referidas pelos autores acima, e está relacionada à quantidade de microrganismos presentes na hora da coleta, pois somente $50 \%$ de pacientes sintomáticas apresentam teste direto positivo, justificando-se a realização do Gram e cultura, em casos de recorrência.

Todas as culturas positivas para fungo revelaram tratar-se de casos de candidiase da espécie albicans $(17,1 \%)$. Em pesquisa realizada num ambulatório de ginecologia da cidade de Taubaté, cidade vizinha de Tremembé, NASCIMENTO e col. (1999) relataram prevalência de $20,2 \%$ de Candida sp, sendo que $78,5 \%$ eram da espécie albicans. DI BARTOLOMEO 
e col. (2002) descrevem percentuais de $17,8 \%$ de Candida sp, em secreções de mulheres adultas, e PÁJARO e col. (2001) reportam 21,3\% de mulheres com C. albicans, citando ainda $5,1 \%$ de associações de vaginose bacteriana com candidiase, percentuais próximos aos obtidos neste trabalho, considerando-se apenas os resultados de cultura.

Quanto ao diagnóstico de vaginose bacteriana, verificou-se que $18,1 \%$ dos esfregaços apresentavam esse padrão, segundo os critérios de Nugent, associado, ainda, à presença de mais de $20 \%$ de clue cells, as quais também foram observadas em igual número de lâminas, ao exame direto "a fresco". Na literatura, encontram-se percentuais bastante variados, nos quais se inserem os dados apresentados. Assim, CANTO-DE-CETINA e col. (2001) reportam percentuais de $39,4 \%$, em clínica de planejamento familiar; MÉNDEZ e col. (2001), de 33,0\% em um centro de saúde rural; NAVARRETE e col. (2000), em centro de saúde com Programa de Panejamento Familiar, apontam $31,8 \%$ de casos; DI BARTOLOMEO e col. (2002), em estudo de prevalência de microrganismos presentes em secreção vaginal, revelam percentuais de $23,8 \%$; RODRÍGUEZ e col. (2000) descrevem percentuais de $19,7 \%$, em estudo com pacientes com queixa de leucorréia.

Classicamente, a vaginose bacteriana é diagnosticada pela avaliação clinica, empregando-se três dos quatro critérios de Ansel. No entanto, muitos autores adotam também critérios de Nugent, com base no esfregaço corado por Gram, como reportam NAVARRETE e col. (2000) e DI BARTOLOMEO (2002). Verifica-se também na literatura, controvérsia em relação à sensibilidade dos critérios da medida de $\mathrm{pH}$. Porém, de acordo com a maioria dos autores, o que se aceita efetivamente é o teste de aminas positivo e a presença de clue cells (ROSSI e col. 2000, POZO e col. 2000).

NAVARRETE e col. (2000) descrevem que as interferências ocorrem em razão de alterações no $\mathrm{pH}$ devido ao uso de duchas, à presença 
de esperma e infecções por T. vaginalis. SOBEL (1997), acrescenta o quadro de vaginite atrófica, contribuindo todos eles para a elevação do $\mathrm{pH}$. Por essa razão, alguns casos com teste de "Whiff" fracamente positivo, mas com presença de clue cells e escore superior a sete no Gram, foram considerados casos de vaginose bacterina para o estudo em tela.

Em relação às floras intermediárias observadas, verificou-se que ocorreu num percentual um pouco acima do descrito por NAVARRETE e col. (2000), que foi de 12,9\%. Vale destacar, que segundo o estudo de ESCHENBACH e col. (2000), no qual pesquisou-se a flora de mulheres em três períodos do ciclo menstrual, os autores observaram modificações do meio vaginal, assinalando um aumento da flora intermediária do primeiro ao quinto dia do ciclo menstrual; portanto, alguns casos de desequilíbrio da flora vaginal podem estar relacionados apenas com o dia do ciclo e não necessariamente a um possivel quadro de vaginose.

Um achado interessante foi o aspecto citolítico observado em esfregaços tipicamente lactobacilares. Embora seja um processo normal, SOBEL (1997) e HALBE (2001) sugerem que alguns corrimentos podem ser de causa citolítica e muito semelhantes clinicamente, à vaginite por Candida.

A ocorrência de tricomoníase foi constatada em apenas dois casos, estando um deles associado à candidíase. WALRAVEN e col. (2001) citam 6,2\% de casos, enquanto no estudo de MÉNDEZ e col. (2001), os autores relatam $4,0 \%$ de mulheres infectadas por $T$. vaginalis, percentual semelhante ao encontrado por RODRÍGUEZ e col. (2000), que foi de 4,3\%. GERBASE e col. (1999), numa revisão de dados referentes às DST na América Latina, afirmam que a prevalência no Brasil gira em torno de $3,6 \%$. Dentre esses autores, alguns sinalizam a diminuição da prevalência nos últimos anos e a ocorrência de associações de $T$. vaginalis, principalmente com vaginose bacteriana, fato este, que não foi percebido neste estudo. 
Quanto aos quadros de tricomoniase observados no exame direto e Gram, verificou-se perfeita concordância entre as duas metodologias. A facilidade e simplicidade do teste, frente às dificuldades técnicas em realizar a cultura nesse trabalho, foram razōes para adotar como padrão "ouro" os resultados de exame direto, Gram e Papanicolaou. Segundo GRIMES e SHULZ (2002), o uso combinado de testes diagnósticos pode levar a melhores resultados de sensibilidade. Por outro lado, WIESE e col. (2000), na revisão meta-analítica na qual comparam resultados do exame "a fresco" com o teste de Papanicolaou, frisam que em locais de prevalência menor ou igual a $1 \%$, o exame de Papanicolaou pode ser aplicado como teste diagnóstico, desde que as mulheres sejam sintomáticas. Partindo-se do princípio, de que o presente trabalho pesquisou mulheres com corrimento vaginal, tratavam-se portanto, de casos sintomáticos. A sensibilidade e especificidade de ambos os testes, foi excelente no diagnóstico de tricomoníase como mostra a tabela 20.

A avaliação dos esfregaços endocervicais corados por Gram não revelou nenhum caso de diplococo intracelular que pudesse sugerir gonorréia, bem como a cultura do microrganismo, e também não mostrou nenhum caso positivo. $O$ mesmo resultado foi referido por DI BARTOLOMEO e col. (2002), CANTO-DE-CETINA e col. (2002), GERBASE e col. (1999), WALRAVEN e col. (2001).

CODES e col. (2002), encontrando $0,5 \%$ de gonorréia nas mulheres pesquisadas, dão uma explicação bastante lógica em relação a essa baixa prevalência, afirmando que a gonorréia sendo sintomática no homem, faz com que ele procure rapidamente o tratamento, reduzindo dessa forma as chances de transmissão à sua parceira.

Por outro lado, a contagem semi-quantitativa de leucócitos no esfregaço endocervical teve por objetivo testar sua eficiência como fator preditor de infecções por $C$. trachomatis ou $N$. gonorrhoeae em fluxogramas 
de abordagem sindrômica, sempre que houver disponibilidade de exames de laboratório, pela facilidade da técnica.

Inicialmente, em alguns protocolos, indicava-se contagem maior ou igual a cinco leucócitos por campo, como parâmetro indicativo de infecção por $C$. trachomatis e N. gonorrhoeae. Porém, de acordo com o CDC (1998), esse número só era aplicável em mulheres sintomáticas e em regiões de alta prevalência. IGLESIAS e col. (2000), citando o trabalho de Holmes, referem contagem maior ou igual a 30 neutrófilos e presença de muco, como parâmetros. SELLORS e col. (1998), IGLESIA e col. (2000) referendam a contagem igual ou superior a 10 polimorfonucleares para um melhor desempenho do teste. PÁJARO e col. (2001) confirmam que uma contagem superior ou igual a 10 leucócitos por campo microscópico, melhora a especificidade do exame, para o diagnóstico de infecções por $C$. trachomatis.

Neste trabalho, a contagem de leucócitos maior ou igual a 10 polimorfonucleares em campo microscópico de 1000X, não teve significância estatística, não sendo recomendado seu uso como ferramente auxiliar no diagnóstico de cervicites mucopurulentas. A sensibilidade encontrada no teste para esse fim foi de $66,7 \%$, especificidade $62,7 \%$ e valor preditivo positivo de apenas $5,0 \%$ (tabela 20 )

No presente estudo, foram detectados três casos de $C$. trachomatis empregando-se a pesquisa de antígenos no teste de imunofluorescência direta (IFD), como recomenda o MINISTÉRIO DA SAÚDE (1999). Atualmente, as técnicas de eleição são baseadas em procedimentos moleculares. No entanto, nenhuma delas, nem tampouco a cultura celular, é aplicável em laboratórios de saúde pública (MARTINEZ, 2001) 
GERBASE e col. (1999) referem taxas de $22,8 \%$, em estudo brasileiro de população usuária de centro de saúde, empregando a mesma metodologia. BASTOS e col. (2002), pesquisando população de grávidas e não-grávidas com um sistema automotizado "Mini-Vidas" para $C$. trachomatis reportam uma prevalência de $3,4 \%$ em mulheres não-gestantes de um centro de saúde do Rio de Janeiro. CODES e col. (2002), citam $11,4 \%$ de casos em clínica de planejamento familiar da rede pública, empregando teste molecular em amostras de urina. Assim, confirma-se grande variabilidade dos resultados que, segundo MARTíNEZ (2001), pode ser atribuida a diversos fatores tais como, prevalência e metologia empregada.

Em relação ao teste de IFD, MELLES e col. (2000), complementam que a sensibilidade do método está na dependência do ponto de corte da contagem dos corpúsculos elementares, do número de células coletadas e da capacitação na leitura. Na pesquisa em tela, todas as lâminas tinham material suficiente e nenhum resultado foi considerado "borderline", uma vez que o técnico que avaliou o material, microscopicamente, era profissional especializado.

O resultado de $2,8 \%$ casos de infecção por $C$. trachomatis evidenciados neste trabalho, embora deva ser considerado com ressalvas, diante das limitaçōes da metodologia e da amostra pesquisada, trouxe sem dúvida, valiosa contribuição ao conhecimento da prevalência dessa DST em mulheres do município de Tremembé visto que, não havia nenhum dado a respeito da doença em nivel local e, nem sequer, em nível regional.

Nas tabelas 15, 16 e 17, que apontam os dados obtidos em relação ao teste de Papanicolaou, verifica-se que $83,8 \%$ das pacientes tinham citologias inflamatórias e, dessas, $47,6 \%$ apresentaram metaplasia escamosa, a qual, na maioria das vezes, é patognomônica de quadros de cervicite. Assim, nota-se que esse percentual tem estreita relação com o 
número também elevado de colos uterinos com ectrópio encontrados no trabalho.

MOTTA e col. (2001) descrevem um número bem inferior em relaçāo a casos de citologia inflamatória, pesquisados num ambulatório de ginecologia, cujo percentual foi de $59,9 \%$, bem como para os casos de NIC II $(0,2 \%)$. Em relação ao efeito citopático do HPV, os autores relatam percentual de 3,3\%. Segundo o INCA (2002), na avaliação do projeto piloto do Programa Viva Mulher, a taxa de casos com efeito citopático do HPV variou de $4,4 \%$ a $11,5 \%$, e de NIC II, entre $1,7 \%$ a $5,6 \%$, sendo que as taxas mais elevadas ocorreram, nas regiōes brasileiras do Norte e Nordeste.

Quanto à flora microbiológica, sugerida no teste de Papanicolaou, há diversas controvérsias na literatura, principalmente no que diz respeito ao local da coleta. No teste de Papanicolaou, geralmente colhe-se material endo-ectocervical, enquanto que para o diagnóstico de vaginites, o local ideal é o fundo de saco vaginal. Mesmo assim, constatase uma boa especificidade do teste (EGAN L LPSKY 2000, CHECAe SANCHEZ2001, HALBE 2001).

No presente estudo, o teste de Papanicolaou evidenciou 12,4\% casos sugestivos de Gardnerella vaginalis e $4,8 \%$ de candidíase, obtendo $61,1 \%$ de sensibilidade e $97,7 \%$ de especificidade; $27,7 \%$ e $100,0 \%$, respectivamente (tabela 20). Autores da área de citopatologia admitem que, mesmo sendo inferior a outras técnicas, o método de Papanicolaou ainda alcança sensibilidade suficiente para ser indicativo para esses diagnósticos (MOTTA e col. 2001, AVILÉS e col. 2001). Os mesmos autores referem, em seus trabalhos, prevalência de $8,6 \%$ de Gardnerella vaginalis e $33,9 \%$ de candidiase em esfregaços corados pelo método de Papanicolaou, citando porém, sensibilidade em torno de $20 \%$ e especificidade de mais de $90 \%$ para candidiase, e $60 \%$ a $90 \%$ de sensibilidade e especificidade para vaginose bacteriana, respectivamente, valores semelhantes aos encontrados neste estudo (tabela 20). 
Segundo HALBE (2000), IGLESIAS e col. (2000), para o diagnóstico de $T$. vaginalis, há melhor aceitação do teste, por suas propriedades tintoriais; pela fixação da lâmina em álcool, que preserva as estruturas do protoparasita; bem como por alterações citopáticas características, o que remete à ótima sensibilidade, confirmada também nesse trabalho (tabela 20)

No inicio da década de 80 , vários trabalhos faziam referência à presença de vacúolos citoplasmáticos com inclusões, em células da camada profunda ou em células metaplásicas, como presuntivos de diagnóstico de C. trachomatis.

Ao longo do tempo, outras pesquisas comprovavam que tais vacúolos tratavam-se de outros processos do metabolismo celular e que não tinham relação com a infecção por $C$. trachomatis. Porém, o que se firmou é que a presença de linfócitos, histiócitos e outras células de linhagem plasmocítica, associadas ou não à metaplasia escamosa, estariam verdadeiramente envolvidas com esse processo inflamatório (KIVIAT e col. 1985).

Nesse sentido, BASTOS e col. (2002) afirmam que atipias em células metaplásicas e endocervicais podem ser observadas na junção escamo-colunar, onde células metapásicas imaturas se localizam em maior quantidade e em maior atividade metabólica. Estas células são expostas à ação de virus oncogênicos, aos quais, são mais suscetiveis e, por conseguinte, a metaplasia atípica induzida por C. trachomatis, poderia tornar - local também suscetivel ao HPV, o qual tem sub tipos potencialmente oncogênicos. Assim, os autores justificam a associação entre infecção por $C$. trachomatis e de neoplasia intraepitelial cervical do colo uterino, fato que poderia explicar o encontro dessa associação em uma das mulheres desta pesquisa. 
A partir dessas premissas, delineou-se a proposta de um escore de risco, que pudesse vir a ser útil no diagnóstico de cervicite por $C$. trachomatis, uma vez que, na nossa realidade, outras técnicas mais sensiveis não são acessíveis, e o diagnóstico tal como sugerido no protocolo de citopatologia, é sabidamente ultrapassado e incorreto. Soma-se a esses fatos, o de que o clínico tem no Papanicolaou o seu único instrumento auxiliar de diagnóstico microbiológico na maioria dos serviços da rede pública. É obvio que há de se mudar tal realidade, porém foge ao escopo da fundamentação técnica, passando para uma área mais complexa que envolve as políticas de saúde.

Verificou-se que a indicação da contagem de leucocócitos equivalente a $2+$, associada à presença de células endocervicais reativas e/ou presença de metaplasia escamosa, tiveram sensibilidade de $66,7 \%$, especificidade de $83,3 \%$ e OR=5,3 (tabela 21), evidenciando que o indicador proposto neste estudo para o diagnóstico presuntivo de $C$. trachomatis, poderia ser empregado. Esses valores são superiores aos referidos por SELLORS e col. (1998), avaliando a presença de leucócitos, como indicador presuntivo da doença que foram de $18,9 \%$ de sensibilidade e $97,0 \%$ de especificidade.

Sem dúvida, estudos mais amplos devem ser realizados para confirmar sua utilização, especialmente, no que diz respeito ao baixo valor preditivo positivo encontrado, inerente ao tamanho da amostra e a prevalência de $C$. trachomatis nesta população. No entanto, diante da importância de se ter a mão o diagnóstico da doença, e, diante das dificuldades em se empregar as técnicas laboratoriais que continuam inacessiveis em ambulatórios da rede pública, parece válido, investir num projeto mais amplo que confirme ou não seu uso. 
Nas tabelas 18 a 25, os resultados são avaliados estatisticamente destacando-se também o perfil sociodemográfico, gineco obstétrico e comportamental dos casos positivos.

A abordagem sindrômica evidenciou melhor sensibilidade e valor preditivo positivo daquela descrita por MOHERDAUI e col. (1998). Considerando-se que aquele estudo foi realizado em unidade de referência de DST, onde a metodologia tem melhor desempenho e alta prevalência, verifica-se que os dados aqui descritos foram de $66,7 \%$ de sensibilidade, $83,3 \%$ de especificidade e $10,5 \%$ de valor preditivo positivo.

Em todos os estudos empregando-se a abordagem sindrômica em corrimentos, referem o baixo valor preditivo positivo, ou seja, menor que $25 \%$. As explicações dizem respeito à: baixa prevalência; caracteristica assintomática e inespecífica da infecção. Logo, em todos eles, o que mais se investiga, é a associação com os possiveis fatores de risco, que poderiam trazer um aumento efetivo ao valor preditivo positivo e também à sensibilidade. Em vários estudos analisados por DALLABETTA e col. (1998), os autores referem sensibilidades reportadas de 30 a $60 \%$ em média; especificidade de 60 a $80 \%$ e valor preditivo positivo, na maioria das vezes, menor que $25 \%$. É interessante destacar, que embora tenha se trabalhado com uma amostra muito menor do que a referida pelos autores, os valores obtidos no presente estudo, foram extremamente satisfatórios.

A tabela 22 evidencia as principais características identificadas como de risco às DST. $A$ idade das pacientes não teve associação significativa, bem como outras variaveis clássicas, tais quais, os aspectos clínicos do colo (friabilidade, dor à mobilização) e DST prévia ou do parceiro, dentre outras. Caracterizaram-se como de risco, o comportamento sexual da paciente e outras variávies de natureza clínica, como cor da leucorréia, medida de $\mathrm{pH}$ e teste de Whiff. Confirmou-se também, a associação significativa do escore do risco proposto pelo Ministério da Saúde. 
SELLORS e col. (2000), estudando características visuais de leucorréia, associou significativamente à infecção por $C$. trachomatis, a cor "amarela opaca" da leucorréia com valores de ODDS de 2,8 .

Em relação ao aspecto do corrimento, as diferentes caracterizaçōes da leucorréia são muito abstratas, uma vez que adjetivos como "homogênea", "cremosa" ou tonalidades tão indistintas, como "brancoamarelado" tornam sua interpretação um problema de ordem semântica. Assim diversos autores, já questionaram tais características, para definir o aspecto do corrimento (ROSSI e col. 2000, EGAN e LIPSKY 2000). Ainda assim, verificou-se que, em relação à sensibilidade do escore em estudo o resultado foi satisfatório, frente a outros escores descritos na literatura.

A partir da identificação dessas variáveis, foram propostos alguns modelos, onde acrescentou-se cada uma das variáveis significativas, aos escores já indicados para uso no Brasil com finalidade de testar os resultados de sensibilidade, especificidade e valor preditivo positivo.

De todos os modelos propostos, a associação que obteve um discreto aumento na especificidade e no valor preditivo positivo, foi a variável cor da leucorréia "amarela ou outra" (tabela 24), com sensibilidade de $66,7 \%$, especificidade de $79,4 \%$ e valor preditivo positivo de $12,5 \%$.

Esse resultado, leva a inferência que sendo a especificidade boa, identifica os verdadeiros casos negativos da população, assim, evita sobretratamentos, o que torna válida a adoção dos escores propostos. Um dos grandes entraves na abordagem sindrômica, é o custo elevado gerado no Sitema de Saúde, diante de tratamentos desnecessários (MINISTÉRIO DA SAÚDE 1999, HAWKES 1999). 
Outro fator é de ordem psicossocial, visto que um resultado falsopositivo, podera ter graves consequências na vida conjugal do casal, bem como contribuir para que a mulher se sinta discriminada, no seu convivio social (FERNANDES e col. 2000).

Comparando-se com outros estudos, como o de WARD e col. (2001) na Jamaica, em que foram testados vários escores de risco, os autores não validaram a proposta de escores de risco com baixos valores preditivos positivos; em torno de $25,0 \%$. Por outro lado, FONCK e col. (2000), também encontraram associação positiva entre DST e mulheres com cor da leucorréia amarela, porém ressaltam que a sensibilidade foi de $55,0 \%$, especificidade de $29,0 \%$, embora com OR=3,0.

Em ralação aos microrganismos identificados no estudo, verificouse que a vaginose bacteriana teve uma boa especificidade e sensibilidade no diagnóstico realizado através da abordagem sindrômica e teve o melhor valor preditivo positivo $(55,9 \%)$ (tabela 20 ). No trabalho de HAWKES e col. (1999) o resultado foi bem inferior em relação à vaginose bacteriana, que teve uma especificidade zerada. Nos algoritmos testados por FONK e col. (2000), os valores preditivos obtidos tiveram taxas variando de $18 \%$ a $22 \%$. A candidíase teve o pior desempenho em relação à sensibilidade, no entanto teve uma boa especificidade $(88,5 \%)$, porém obteve valores superiores aos descritos pelos autores acima, variando de 42 a $73 \%$ em vários modelos testados.

$\mathrm{Na}$ tabela 25, são apresentadas as associaçōes significativas para os quadros de vaginose bacteriana e candidíase. Nos casos de candidiase, estavam associados significativamente ao fator escolaridade e medida de ph< 4,5. No caso de vaginose, o método contraceptivo e o número de filhos, teve significância estatística. Ambos foram discutidos nos tópicos anteriores deste trabalho. O comportamento sexual, como era de se esperar, foi significativo estatisticamente para as pacientes positivas para DST, não 
sendo significativo para aquelas que apresentaram infecções endógenas, tal como também descreve HAWKES e col. (1999).

Esses resultados mostram que, a proposta de um algoritimo para o município de Tremembé seria a mesma, já preconizada pelo Ministério da Saúde, podendo ser acrescentado o escore de risco cor da leucorréia.

O escore de risco, empregando-se o método de Papanicolaou, poderia ser aplicado, como diagnóstico presuntivo de cervicite por $C$. trachomatis, porém demanda de articulações interinstitucionais mais amplas, integrando os Programas de Prevenção de Câncer do Colo Uterino com o Programa DST/ AIDS.

Diante da realidade nacional, parece claro e necessário uma ação conjunta em todos os níveis, no sentido de apreveitar estruturas existentes e investir em tecnologias simples e baratas, muitas vezes já existentes, que promovam a saúde da população.

Assim, este trabalho mostrou que a abordagem sindrômica, ainda que com limitaçãoes nas taxas de valor preditivo positivo, vislumbra a possibilidade de nortear o procedimento do clínico no seu diagnóstico, tanto, das DST, quanto, das vaginites e vaginoses, empregando métodos extremamentes simples e baratos.

Isso o conduzirá, no mínimo, a elaborar um diagnóstico mais preciso, e assim, não serão instituidos tratamentos desnecessários, o que do ponto de vista econômico, é também extremamente favorável ao provedor de saúde. Por outro lado, a mulher também estará protegida dos efeitos psicossociais de um diagnóstico falso-positivo. 


\section{CONCLUSÕES}

A abordagem sindrômica para corrimentos vaginais foi validada para o emprego no Município de Tremembé, por ser uma técnica simples e barata, atingindo bons níveis de especificidade em todos os diagnósticos e consequentemente, evitando sobretratamentos.

A prevalência de $T$. vaginalis foi de, $1,9 \% ; C$. trachomatis, de $2,8 \%$; Candida sp, de 17,1\% e vaginose bacteriana também de $17,1 \%$.

Os casos de $C$. trachomatis e $T$. vaginalis tiveram associação estatisticamente significativa com o comportamento sexual em relação à multiplicidade de parceiros num período menor de tempo, bem como com a cor "amarela ou outra" do corrimento $(p<0,08)$; medida de $\mathrm{pH}>4,5(p=0,08)$; teste de "Whiff" $(p=0,08)$.

A associação das variávies estatisticamente significativas, destacaram o melhor desempenho de sensibilidade, especificidade e valor preditivo positivo, quando se fez a associação dos escores comportamentais " $\geq 2$ " do Ministério da Saúde, com a variável cor da leucórreia "amarela ou outra".

O escore testado na leitura complementar de Papanicolaou, correspondente a leucócitos quantificados em 2+, associado à presença de metaplasia escamosa com vacúolos, sem inclusões intracitoplasmáticas e presença de células endocervicais reativas, mostrou significância estatística, $\mathrm{OR}=5,3182$ e taxas de sensibilidade, especificidade e valor preditivo positivo de $66,7 \% ; 83,3 \% ; 10,5 \%$, respectivamente. 


\section{REFERÊNCIAS BIBLIOGRÁFICAS}

1. Adad SJ, Lima RV, Sawan ZTE, Gobo MLS, Souza MAH, Saldanha JC, Cunha VAAFAH, Murta EFC Frequency of Trichomonas vaginalis, Candida $\mathrm{sp}$ and Gardnerella vaginalis in cervical-vaginal smears in four different decades. São Paulo Med J. 2001: 119 (6): 200-205

2. AIDSCAP/Family Health Intemacional. Making Prevention Work Global Lessons Learned from the AIDS Control and Prevention. Arlington, Vriginia; 1998 (AIDSCAP project 1991-1997).

3. Amaral E. Current Aproach to STD management in women. Int J Gynecol \& Obst 1998; 63 Suppl 1: 183-189.

4. Antonio MAD, Hawes SE, Hillier SL. The identification of vaginal Lactobacillus species and the demographic and microbiologic characteristics of women colonized by these species. J of Inf Dis 1999;180:1950-1956

5. Araújo MAL, Bucher JSNF, Bello PY. Análise das fichas de atendimento de pacientes com doenças sexualmente transmissiveis nas unidades de referência de Fortaleza, 2000 e 2001. J bras Doenças Sex Transm 2002; 14 (4): $18-22$.

6. Avilés AGP, Zaragoza CO, Barrera, LT, Vasquez RM, Rosas, RP ¿ Es útil la tinción de Papanicolaou como auxiliar del diagnóstico de algunas infecciones de transmisión sexual? Aten Primaria 2001; 27: 222-226.

7. Bastos CA, Bravo RS, Lopes HR, Figueiredo. Identificação de Chlamydia trachomatis, Micoplasma hominis e Ureaplasma urealyticum, em gestantes e não gestantes. J bras Doenças Sex Transm. 2002; 14 (1): 31-37.

8. Belda W. Importância atual das uretrites nas doenças sexualmente transmissiveis. J Inform Urológicas 1985 b, 19 [Encarte]. 
9. Belda W. Sifilis - atualidade permanente. J Inform Urológicas 1985 a, 17 [Encarte].

10. Belda, W. Conceito e Classificação. In: Passos, M.R.L. Doenças sexualmente transmissíveis. $3^{a}$ ed. Rio de Janeiro: Cultura Médica, 1991. p. 1-7.

11. Benzaken AS, Pedrosa V, Garcia EG, Dutra J, Sardinha JCG. Utilidade do escore de risco padrão no Brasil na avaliação da infecção gonocócica em mulheres com corrimento vaginal. J bras Doenças Sex Transm 2001 13(5): 4-7

12. Bier O. Microbiologia e Imunologia. São Paulo: Melhoramentos, 1994

13. Bosu WK. Syndromic management of sexually transmitted diseases: is it rational or scientific? Trop Med International Health. 1999; 4(2): 114-119.

14. Brabin L. Clinical management and prevention of sexually transmitted diseases: a review focusing on women. Acta Tropica 2000; 75: 53-70.

15. Canto-de Cetina TE, Polanco-Reyes, González VF, Dzul GC Prevalência de vaginosis bacteriana en un grupo de mujeres de una clínica de planificacion familiar. Gac Méd Méx 2002; 138 (1): 25-30.

16. Cardoso J A S. DST na Infecção HIV. In: I Congresso Virtual HIVIAIDS; [comunicação on line]. 3/10/2000 e 01/12/2000. AidsPortugal. com. Disponivel em <URL: http://www.aidscongress.net/article.php?sid=82/> [2002 jun]

17. Castle PE, Hillier, SL, Rabe LK, Hildesheim A, Herrero R, Bratti MC, Sherman ME, Burk RD, RODRIGUEZ AC, Alfaro M, Hutchinson ML, Morales J. Schiffman M. An association of cervical inflammation with high-grade 
cervical neoplasia in women infected with oncogenic Human Papillomavirus (HPV) Cancer Epid Biomarkers \& Prevention 2001; 10: 1021-1027.

18. Catchpole M. Sexually transmitted infections: control strategies [Editorial]. BMJ 2001; 332: 1156-1136.

19. [CDC] Center of Diseases Control. Cervical cancer screening for women who attend STD Clinics or have a history of STDs. Guidelines for Treatment of Sexually Transmitted Diseases. MMWR 1998; 47(RR-1);1-118.

20. [CDC] Centers for Disease Control and Prevention. Division of STD Prevention. Tracking the Hidden Epidemics-Trends in STDs in the United States 2000. Atlanta, 2000.

21. Checa E V, Sánchez EV. Vaginitis. Salud Total de la Mujer 2001;3(2):96105.

22. Codes JS, Cohen DA, Melo NA, Santos AB, Codes JJG, Silva Junior JC, Rizzo R. Deteç̧ão de Doenças Sexualmente Transmissiveis em Clínica de Planejamento Familiar da Rede Pública no Brasil. Rev bras ginecol obstet 2002 24(2): 101-106.

23. Dadian MJ. Syndromic Management: Promoting Effective STD Diagnosis in Resource-Poor Settings. AIDScaptions [serial online] 1996; 3 (1). Available from: <URL:http: //www fhi. org/ en/ aids/ aidscap /aids pubs/serial/ captions / $33-1 / \mathrm{cp} 313 . \mathrm{html}>$ [2001 mar].

24. Dallabeta GA, Gerbase AC, Holmes KK. Problems, solutions and challenges in syndromig management of sexually transmitted disease. J sex transmitted infection. 1998; 74 Supl1:1S-11S

25. Davies MF, Patruno JE. Vaginitis: Case Studies Obst and Gynec 2000: 6 (3): $2-16$ 
26. Di Bartolomeo S, Fermepin MR, Sauka DH, Torres RA. Prevalencia de microorganismos asociados a secreción genital femenina, Argentina. Rev Saúde Pública 2002; 36(5): 545-52

27. Egan ME, Lipsky MS. Diagnosis of vaginistis. Am Fam Physician 2000; 62: 1095-1104.

28. Eschenbach DA, Thwin SS, Patton DL, Hooton TM, Stapleton AE, Agnew K, Winter C, Meier A, Stamm WE. Influence of the normal menstrual cycle on vaginal tissue, discharge and microflora. Clin Inf Dis. 2000; 30: 901-907

29. Fernandes AMS, Antonio DG, Bahamondes LG, Cupertino CV. Conhecimento, atitudes e práticas de mulheres brasileiras atendidas pela rede básica de saúde com relação às doenças de transmissão sexual. Cad Saúde Pub. 2000; 16(supl. 1): 103-112.

30. Fernández ML, Lombardia J. Vulvovaginitis y cervicitis en la práctica diaria. SEMERGEN. 2002; 28 (1): 15-20.

31. Fonck K, Kidula N, Jaoko W, Estambale B, Claeys P, Ndinya-Achola J, Kirui $P$, Bwayo J, Temmerman M. Validity of the vaginal discharge algorithm among pregnant and non-pregnant women in Nairobi, Kenia. Sex Transm Inf 2000; 76:33-38.

32. Formenti L. Governo quer controlar doenças sexualmente transmissiveis. $\mathbf{O}$ Estado de São Paulo jjomal on line] São Paulo 2002; Disponivel em <URL: http:// www. estado. estadao. com. br/ editorias/2002/08/28/ger016.html> [2002 ago].

33. Fundação Perseu Abramo. A mulher brasileira nos espaços público e privado. Pesquisa Nacional 2001-Núcleo de Opinião Pública. [on line] São Paulo 2002; Disponível em <URL: http :/l www. fpabramo. org. brl nop/mulheres/apresentacao.htm $>$ [2002 ago] 
34. Fundação SEADE. Informações dos Municípios Paulistas [on line] São Paulo 2002; Disponivel em <URL: http://www.seade.gov.br/cgibin/lingcv98/spd_01.ksh?n1=25> [2002 dez].

35. Gardner E, Gray DJ, Rahilly RO. Anatomia. $4^{\mathrm{a}}$ ed. Rio de Janeiro: Guanabara, 1988.

36. Gerbase AC, Toscano C, Titan S, Cuchi P, González-Salvatierra R, Zacarias. Sexually transmitted diseases in Latin América and the Caribbean. Rev Panam Salud Publica. 1999; 6(5): 363-370.

37. Giraldo MV, Botero SE, Acevedo LT, Arredondo MV, Peña MEV. Validación de la prueba de Papanicolaou en el diagnóstico de vaginosis bacteriana. Antioquia, Colômbia. IATREIA 2002; 15 (1):50-55

38. Grimes DA, Schulz KF. Uses and abuses of screening tests. Lancet 2002; 359: 881-883.

39. Halbe HW Corrimento vaginal: deve-se tratá-lo antes do resultado dos exames complementares? Sinopse de Ginecol e Obst [periódico on line] 2000; 3. Disponivel em <URL: http: //www. cibersaude. com.br / revistas. asp? Fase $=002 \&$ id_edição $=160>$ [2001 maio]

40. Hawkes S, Morison L, Foster S, Gausia K, Chakraborty J, Peeling RW, Mabey D. Reproductive-tract infections in women in low-income, lowprevalence situations: assessment of syndromic management in Matlab, Bangladesh. Lancet 1999; 354: 1776-81.

41. Hyppólito SB. Status of STD Screening, Diagnosis and Treatment in Ceará, Brazil In: Issues in Management of STDs in Family Planning Setting STDs Workshop Proceedings; 1995 Apr 19-21; Baltimore (USA); 1996. p. 40-41. 
42. [IBGE] Instituto Brasileiro de Geografia e Estatistica. Censo 2000Informações sobre os 5.507 municipios brasileiros [on line] 2002. Disponivel em: <URL: http://www.ibge.gov.br/ instituto brasileiro de geografia e estatística_arquivos/20122002censo.htm $>$ [dez 2002].

43. Iglesias EA, Alderman E, Fox AS. Use de wet smears to screen for sexually transmitted disease. Infect med 2000; 17(3): 175-185.

44. [INCA] Instituto Nacional de Câncer. Coordenação de Programas de Controle de Câncer - Pro-Onco. Programa Viva Mulher[home page] 2002. Disponivel em: <URL: http: //www. inca. org.br/prevencao/pro gramas/viva_mulher/index. html> [dez 2002].

45. Jiménez AL, Gotlieb SLD, Hardy E, Zaneveld LJD Prevenção de doenças sexualmente transmissíveis em mulheres: associação com variáveis sócioeconômicas e demográficas. Cad Saúde Pub. 2001; 17(1):55-62

46. Kiviat NB, Paavonen JA, Brockway J, Critchlow CW, Brunham RC, Stevens CE, Stamm WE, Kuo CC, Derouen T, Holmes KK. Cytologic manifestations of cervical and vaginal infections. I- Epithelial and inflammatory cellular changes. JAMA1985; 253: 989-96,

47. Larsen B, Monif GRG Understanding the Bacterial Flora of the Female Genital Tract. Clin Inf Dis 2001;32: 69-77

48. Martinez MA. Diagnóstico microbiológico de Chlamydia trachomatis:estado actual de un problema. Rev chil infectol 18 (4): 275-284

49. Mayaud P, Hawkes S, Mabey D Advances in control of sexually transmitted diseases in developing countries Lancet 1998; 351 (suppl III): 2932

50. Melles H H B, Colombo S, Linhares I, Siqueira LFG. Avaliação de parâmetros para o diagnóstico laboratorial de infecção genital feminina por 
Chlamydia trachomatis. Rev Soc Bras de Medicina Tropical 2000; 33(4):355-361.

51. Meloni EV, Badianib R, Dal Fabbroa AL, Rodrigues Junior AL. Características do uso de métodos anticoncepcionais no Estado de São Paulo. Rev Saúde Pública 2001; 36(3):263-70.

52. Mendes C. Método de Gram auxilia no diagnóstico das infecções genitais femininas [artigo on line] Fleury - Centro de Medicina Diagnóstica. São Paulo(SP); 2001. Disponivel em <http://www. fleury. com. br / index _ ie. $h t m>[2001 \mathrm{dez}]$

53. Méndez M, Calderón J, Soria A, Yui M, Apaza N. Vaginosis bacteriana: diagnóstico y prevalência em um Centro de Salud. Ginecol Obstet Peru 2001; 47 (1): 58-61.

54. Ministério da Saúde. Coordenação Nacional de DST e Aids. Vigilância Aprimorada das DST- Situação Atual. Bol Epidem de DST [periódico on line].1998a; Disponivel em <URL: http://www .aids. gov .br/ udtv/ bol_dst 98/ vig_aprimorada.htm $>[2001$ mar].

55. Ministério da Saúde. Coordenação Nacional de DST e Aids. Vigilância epidemiológica das DST por meio da notificação de casos [documento on line] 2002; Disponivel em <URL :http ://www .aids .gov. br/ uvad /vigidst $. h t m>[2002$ mar] .

56. Ministério da Saúde. Secretaria de políticas de saúde. Coordenação Nacional de DST e Aids. Documento de referência para a política de controle das DST no Brasil. [documento on line]. agosto 1998b; Disponivel em <URL: http://www.aids.gov.br/assistencia/politica.htm> [2001 mar].

57. Ministério da Saúde. Caderno de Informações de Saúde. Demografia Município:Tremembé. [documento on line] 2002a; Disponivel em <URL: 
http://portalweb02.saude.gov.br/saude/aplicacoes/tabfusion/tabfusion.cfm> [agosto 2002]

58. Ministério da Saúde. Secretaria de Projetos Especiais de Saúde. Coordenação de Doenças Sexualmente Transmissíveis e Aids. Manual de Controle das Doenças Sexualmente Transmissíveis. $3^{\mathrm{a}}$ ed. Brasilia (DF); 1999: $142 \mathrm{p}$.

59. Moherdaui $F$, Vuylsteke $B$, Siqueira $L F$, dos Santos Junior $M Q$, Jardim $M L$, de Brito A M, de Souza M C, Willers D, Sardinha J C, Benzaken A S, Ramos $M C$, Bueno $H$, Rodrigues $L G$, Chequer $P$ J. Validation of national algorithms for the diagnosis of sexually transmitted diseases in Brazil: results from a multicentre study. Sex Transm Infect 1998; 74 Suppl 1:S38-43.

60. Motta EV, Fonseca AM, Bagnoli VR, Ramos LO, Pinotti JA. Colpocitologia em ambulatório de ginecologia preventiva. Rev Ass Med Brasil 2001; 47 (4): 302-10.

61. Nascimento RC, Santos SIS, Maria A. Prevalência das espécies do gênero Candida em pacientes usuárias de um ambulatório de ginecologia municipal de Taubaté. Rev biociên 1999; 5 (2): 25-30.

62. Navarrete PW, Domínguez MY, Castro E, Zemelman RZ. Evaluación de los criterios de Nugent y Amsel para el diagnóstico de vaginosis bacteriana Rev Méd Chile 2000; 128: 767-71.

63. Nyirjesy P. Chronic Vulvovaginal Candidiasis. Am Fam Physician 2001; 63:697-702.

64. Olinto M T, Galvão L W. Características reprodutivas de mulheres de 15 a 49 anos: estudos comparativos e planejamento de ações. Características reprodutivas de mulheres. Rev Saúde Pública 1999; 33 (1): 64-72 
65. ONUSIDA. Enfoques de salud pública para el control de las ETS: Actualización técnica del ONUSIDA (Colección Prácticas Óptimas del ONUSIDA: Actualización técnica). Ginebra, ONUSIDA, mayo de 1998.

66. Ortayli N, Sahip Y, Amca B, Say L, Sahip N, Aydin D. Curable Sexually Transmitted Infections Among the Clientele of a Family Planning Clinic in Istanbul, Turkey. Sex Transm Diseases 2001; 28 (1): 58-61

67. Pajaro MC, Barberis IL, Rodino S, Pascual L, Agüero M. Epidemiology of sexually transmitted diseases in Rio Cuarto, Argentina. Rev Latinoam Microbiol 2001; 43(4): 157-160.

68. [PATH/UNFPA] Prevenção de HIV I AIDS em locais com poucos recursos Washington; 2001 (Out Look-série especial sobre HIVIAIDS).

69. Periman SE, Kahn JA, Emans J. Should pelvic examinations and Papanicolaou cervical screening be part of preventive health care for sexually active adolescent girls? J of Adol Health 1998; 23: $62-67$.

70. Platz-Christensen JJ, Larsson PG, Sundstrom E, Wiqvist N. Detection of bacterial vaginosis in wet mount, Papanicolaou stained vaginal smears and in Gram stained smears. Acta Obstet Gynecol Scand 1995; 74: 67-70.

71. Powers $C N$ Diagnosis of infectius diseases a cytopathologists perspective. Clin Microbiol Rev 1998; 11: 341-365.

72. Pozo RIC, Moliner RB, Brugueras MC, González LO, Barrera MER. Vaginosis bacteriana. Rev Cub Obst Ginecol 2000; 13 (2): 63-75

73. Rado AM, Mere JF, Garcia M. Riesgo de lãs complicaciones de vaginosis bacteriana em gestantes. Ginecol Obstet (Peru) 2001; 47(3):177-183 
74. Rodríguez CO, Ley $\mathrm{Ng} \mathrm{M}$, Acebo $\mathrm{CL}$, Martinez CA. Vaginosis bacteriana em mujeres com leucorrea. Rev. Cubana Obstet Ginecol 2000; 26 (2): 74-81.

75. Rossi P, Neme RM, Ribeiro RM, Pinotti, JA. Vulvovaginites. Rev Bras Med [periódico on line] 2000; 58(5). Disponivel em <URL: http://www.cibersaude.com.br/revistas.asp?fase=ro03\&id_materia=1456> [2001 mar].

76. Seadi CF, Oravec R, von Poser B, Cantarelli W, Rossetti ML. Diagnóstico laboratorial da infecção pela Chlamydia trachomatis: vantagens e desvantagens das técnicas. J Bras Patol e Med Laboratorial. 2002; 38(2): 125-32

77. Schwebke JR, Richey CM. Correlation of behaviors with microbiological changes in vaginal flora. $\mathrm{J}$ of Infec Dis. 1999; 180:1632-1636.

78. Secretaria de Estado da Saúde de São Paulo. Divisão de Doenças Sexualmente Transmissiveis. Centro de Vigilância Epidemiológica. Doenças Sexualmente Transmissíveis. São Paulo, 1989,.(TBVE: 1 a 5)

79. Secretaria de Estado da Saúde. Grupo de Epidemiologia - Programa Estadual DSTIAIDS - CVE - SES -SP. Relatório dos casos notificados de Doenças Sexualmente Transmissiveis no período de 1987 a 1997 (13/11/97), Estado de São Paulo. Bol Epidem.- SP 1998; 1. Disponivel em <URL: http:// www. aids. gov. brl udtv/ bolestados/ sp1/relat_caso.htm> [2001 mar]

80. Sellors JW, Howard WM, Pickard L, Jang D, Mahony J, Cherneski M. Chlamydial cervicitis: testing the practice guidelines for presumptive diagnosis. CMAJ 1998; 158:41-46.

81. Sellors JW, Howard WM. A new visual indicator of chlamydial cervicitis. Sex Transm Inf 2000; 76: 46-48. 
82. Silva AM, Gomes AML, Matos D, Sant'Anna JV, Melhem MSC e col. Aspectos gerias dos fungos, coloração, reagentes, meios de cultura e principais micoses associadas à AIDS. São Paulo; 1997 (Instituto Adolfo Lutz-Manual de micologia médica, 1).

83. Singh VK, Dubay P, Bhagoliwal A, Kapoor A. Use of Schiller's Test of the cervix to increase the detection rate of cervical dysplasias. J Obstet and Gynecol of India 2001; 51(5):170-172

84. Siqueira LFG, Almeida RG. O laboratório de DST em caráter de pronto atendimento. São Paulo; 1990. [Apostila do Curso do Programa Latino Americano de Aperfeiçoamento em Laboratório de DST-Faculdade de Saúde Pública da USP].

85. Sobel JD. Vaginitis. New Eng J of Med 1997; 26: 1896-1903.

86. Storck MAL, Saraiva AS, Rodrigues AM, Soares CCX. Doenças sexualmente transmissiveis no contexto das "donas de casa". J. bras Doenças Sex Transm. 2001; 16(6): 41-48.

87. Takahashi M. Aparelho genital feminino. $2^{\text {a }}$ ed. São Paulo: Manole 1982 Atlas colorido de citologia do câncer; p. 161-242.

88. [UNAIDSNHO] United National Programme on HIVIAIDS, World Health Organization Brazil-Epidemiological Fact Sheets on HIVIAIDS and Sexually Transmitted Infections 2002 update. Geneva; 2002 (Epidemiological Fact Sheets).

89. Valdivia-Blondet L, Escalante-Jibaja E. El manejo sindrómico de las enfermedades de transmisión sexual. Dermatol Peruana 2000; 10 (Supl. 1) Disponivel em <URL: http: // 200.10.68.58 / bibvirtual / revistas I dermatologia / vol10 sup1/manejo_sind.htm 
90. Vallor AC, Antonio MAD, Hawes SE, Hillier SL. Factors associated with acquisition of, or persistent colonization by, vaginal Lactobacilli: Role of hydrogen peroxide production. 2001; J of Inf Dis 184:1431-1436

91. van Dam CJ. HIV, STD and their current impact on reproductive health: the need for control of sexually transmitted diseases. Int J of Gynecol \& Obst 1995; 50 Suppl 2: S121-129.

92. Vieira EM, Badiani R, Dal Fabbro AL, Rodrigues Jr AL. Características do uso de métodos anticoncepcionais no estado de São Paulo. Rev Saúde Pública 2001; 36(3):263-70

93. Walraven G, Scherf C, West B, Ekpo G, Paine K, Coleman R, Bailey R, Morison. The burden of reproductive-organ disease in rural women in the Gambia, West Africa. Lancet 2001; 357: 1161-1166.

94. Ward E, Spruyt A, Fox L, Johnson L, Wong E, Behets F, Figueroa P, Morris J. Strategies for detection of sexually transmitted disease infection among family planning clients in Jamaica. Int Fam Planning Perspectives 2001; 27 (3): 201-207.

95. [WHO] World Health Organization. Advisory Group on Sexually Transmitted Disease Treatment. Guidelines for the management of sexually transmitted infections.Geneva; 2001a.

96. [WHO] World Health Organization. Global Prevalence and Incidence of Selected Curable Sexually Transmitted Infections Overview And Estimates.Geneva; 2001b.

97. WHO] World Health Organization. Regional Office for the Western Pacific STI, HIV and AIDS Focus. Laboratory Tests for Detection of Reproductive Tract Infections. Manila; 1999a. 
98. [WHO] World Health Organization. Regional Office for the Western Pacific STI, HIV and AIDS Focus. Sexually Transmitted Infections Prevalence Study Methodology - Guidelines for the implementation of STI prevalence surveys. Manila; 1999b.

99. Wiese W, Patel SR, Patel SC, OhI CA, Estrada CA. A meta-analysis of the Papanicolaou smear and wet mount for diagnosis of vaginal trichomoniasis. Am J Med. 2000; 108:301-308.

100. Ziarrusta GB. Vulvovaginitis candidiásica. Rev Iberoam Micol 2002; 19: 22-24. 


\section{ANEXO 1. ALGORITMO PARA ABORDAGEM SINDRÔMICA DE CORRIMENTOS (MINISTÉRIO DA SAÚDE, 1999)}

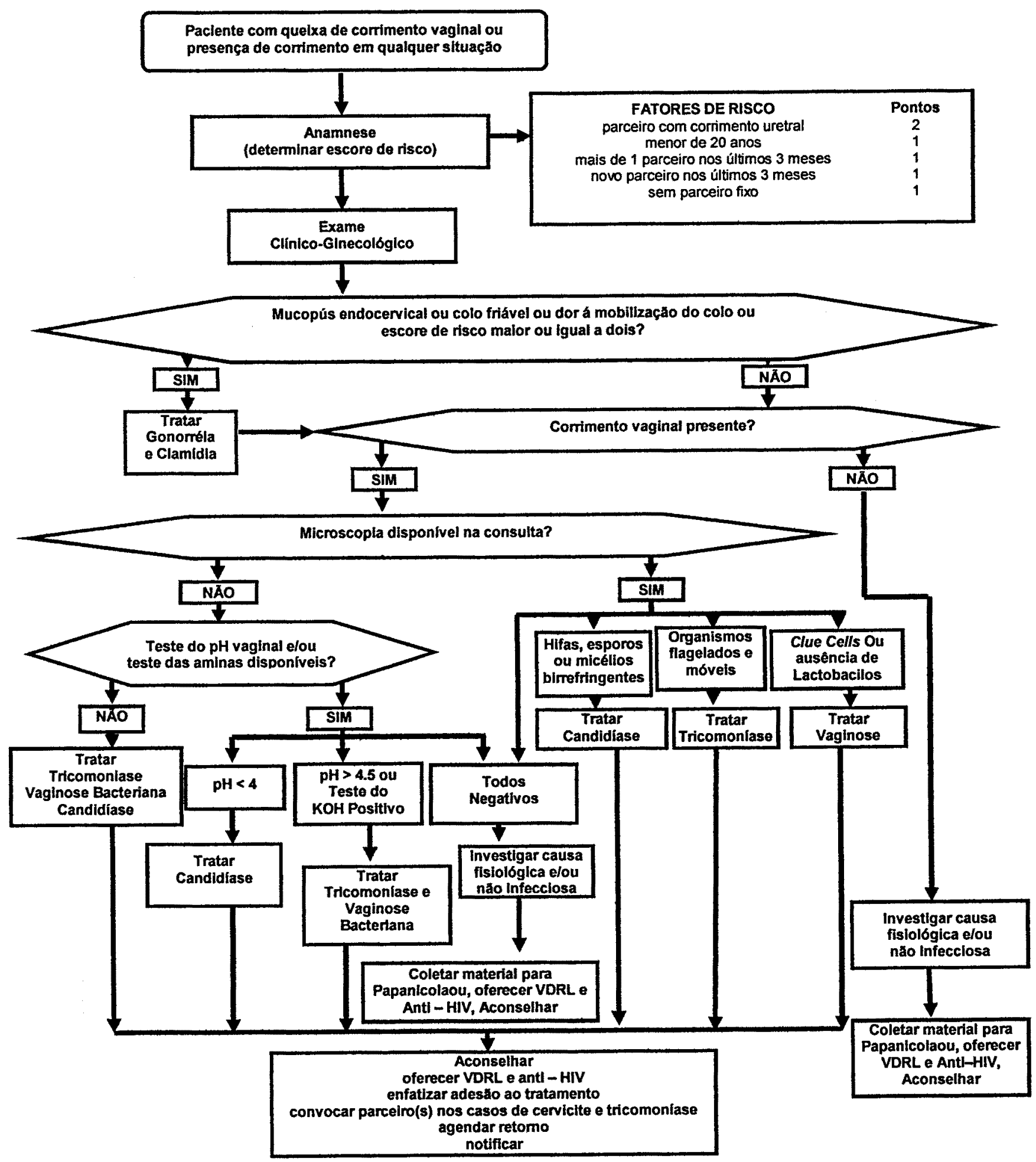




\section{ANEXO 2. CONSENTIMENTO INFORMADO}

Eu, RG: abaixo assinado, declaro que concordo em participar voluntariamente da pesquisa "EMPREGO DA ABORDAGEM SINDRÓMICA DE DOENÇAS SEXUALMENTE TRANSMISSIVEIS EM AMBULATÓRIO DE GINECOLOGIA DA REDE PÚBLICA DO MUNICIPIO DE TREMEMBE - SP”, coordenada por Sandra Irene Sprogis dos Santos, estando ciente e de acordo com os itens descritos abaixo:

$\left.1^{\circ}\right)$ A pesquisa não tem qualquer fim comercial ou lucrativo, nem acarretará despesa de nenhuma natureza, destinando-se a complementar os estudos da coordenadora.

$2^{\circ}$ ) Os objetivos da pesquisa săo aprimorar o diagnóstico dos corrimentos para prevenir contra doenças sexualmente transmissiveis mais graves, como a AIDS, ou de transmiti-las para seus parceiros ou mesmo ao seu bebé, caso venha a engravidar.

$\left.3^{\circ}\right)$ Os exames serăo coletados pelo clínico, após introdução do espéculo vaginal, e a secreção vaginal será obtida de forma indolor, não trazendo nenhum dano à saúde, através de uma espátula de madeira, no caso do teste de Papanicolaou e também com um swab (cotonete) para a realização de cada um dos procedimentos microbiológicos referentes à identificaçăo de: Candida $\mathrm{sp}$. Trichomonas vaginalis, Neissenia gonormoe; pesquisa de Chlamydia trachomatis; pesquisa de leveduras, parasitas e bactérias pelo método de Gram. O teste de "Whiff" e medida do pH vaginal, serăo realizados no momento da consulta, pelo próprio clínico. O material será encaminhado ao laboratório, sendo descartado após seu processamento técnico. Todos os exames såo métodos consagrados na literatura e vocé terá a oportunidade, ao realizá-los, de contribuir para o futuro diagnóstico de corrimento das mulheres da sua comunidade. Porém, se de alguma forma vocé se sentir constrangida, tanto ao responder os itens do questionário, quanto no decorrer da coleta, poderá pedir o desligamento da pesquisa, sem nenhum prejuizo ao andamento normal da consulta, nem aos procedimentos que o médico realiza rotineiramente;

$\left.4^{\circ}\right)$ E garantida a total confidencialidade, privacidade e anonimato dos seus dados pessoais, divulgados na forma de pesquisa, e qualquer dúvida você poderá perguntar ao médico(a) ou entrar em contato com a coordenadora, no Instituto Adolfo Lutz de Taubaté.

$5^{\circ}$ ) Este TERMO DE CONSENTIMENTO, atente às exigências da Resoluçăo 196/96 do Ministério da Saúde e será preenchido em duas vias sendo uma via do paciente e a outra da coordenadora.

Tremembe, de de 2.002 


\section{ANEXO 3. PROTOCOLOS PADRONIZADOS}

Nome da Unidade de Saúde Iniciais do nome No do Prontuário

Idade: Estado civil: Ocupaçăo

Endereço: (rua, avenida, $n^{\circ}$ )

Ponto de referência tel. (contato)

Bairro CEP tel. (contato)

Escolaridade: $\square$ Nenhuma $\square 1^{a}$ a $4^{a}$ série $\square 5^{a}$ a $8^{a}$ série $\square 2^{\circ}$ Grau $\square$ Superior

$\begin{array}{lllll}\text { Renda familiar em salários mínimos } \quad \square \text { até } 2 & \square 3 \text { a } 6 & \square 7 \text { a } 10 \quad 10\end{array}$

Ocupaçăo do parceiro

\section{ANAMNESE}

Inicio da atividade sexual aos anos

$N^{\circ}$ de partos vaginais

$N^{\circ}$ de cesarianas

Mantém atividade sexual? [ NAXO

Parceria fixa? \NÅO D SIM

Relaçôes sexuais nos últimos 5 anos $\square$ só com homens $\square$ só com mulheres $\square$ com homens e mulheres

Mais de um parceiro nos últimos 3 meses? $]$ NÃO $\square$ SIM Novo parceiro no último mês $\square$ NÃO $\square$ SIM

Parceiro refere DST ou outra queixa da área genital? [Não D SIM Qual? Há quanto tempo?

Abortos [ Năo D SIM

No de Espontâneos

No de Provocados

Cauterizaçőes

[ Não [ SIM

Quantas?

Menopausa aos anos

Doença de base: Toma algum medicamento de uso continuo? Qual

Usa ducha elou absorvente intimo? [ NÃO $\mathrm{S}$ SIM Refere DIP, parto prematuro? 0 Năo $]$ SIM

Refere DST anterior ? $]$ Não SIM Qual?

Onde recebeu tratamento? $\square$ farmácia $\square$ médico $\square$ auto-medicaçăo $\square$ outro (especificar)

Usa método contraceptivo? [ Năo $\quad$ SIM

D preservativo masculino

Se sim, a frequência é:

Data da UM I

DDIU — Doral

DOutros Por quanto tempo?

Especificar:

Queixa ginecologica: $\square$ Prurido $\square$ Comimento $\square$ dor/desconforto pélvico $\square$ Outras (especificar) 


\section{AVALIAÇÃO CLINICA}

Colo: $]$ Normal 7 Patológico

Apresenta lesåo? $]$ NÃO $\square$ SIM

Aspecto: $\square$ vesiculosa $\square$ ulcerada $\square$ papilomatosa $\square$ tumoral $\square$ lesס̄es extragenitais onde?

Achados clinicos: $\square$ colpite $\square$ ectrópio $\square$ vulvite $\square$ outro Especificar:

Apresenta leucorréia $\square$ NÃO $\square$ SIM

Quantidade: $\square$ grande $\square$ moderada $\square$ pouca

Cor: $\square$ branca $\square$ amarela $\square$ escura $\square$ com sangue $\square$ outra:

Aspecto: $\square$ aquoso $\square$ pastoso $\square$ mucoso $\square$ Aderente à parede $\square$ outro:

Cheiro: $\square$ azedo $\square$ peixe $\square$ ausente $\square$ outro:

Observaçס̌es:

pH $\quad \square>4,5 \quad \square<4,5$ Teste de "Schiller" $\square$ negativo $\square$ positivo Teste de "Whiff" $\square$ negativo $\square$ positi

Hipótese diagnóstica:

Tratamento instituido:

Foi recomendado tratamento do parceiro? $\square$ Năo $]$ SIM Qual?

Data da colheita: Nome e carimbo do responsável pela colheita do material 


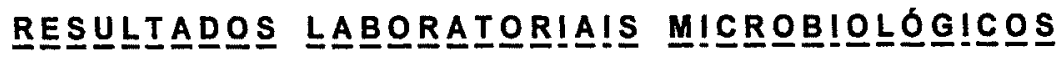

NNDA AMOSTRA

\section{Exame Direto:}

$\begin{array}{llll}\text { Trichomonas vaginalis } & \square \text { Positivo } & \square \text { Negativo } & \square \text { Não realizado } \\ \text { Leveduras/hifas } & \square \text { Positivo } & \square \text { Negativo } & \square \text { Năo realizado } \\ \text { “Clue cells" } & \square \text { Positivo } & \square \text { Negativo } & \square \text { Năo realizado } \\ \text { Outros } & \square \text { Positivo } & \square \text { Negativo } & \text { Especificar: }\end{array}$

\section{Método de Gram:}

Lámina de secreçăo endocervical

$$
\text { Leucócitos em } \square<\text { de 10/campo } \square>\text { de 10/campo em } 5 \text { campos năo adjacentes }
$$

\section{Lámina de secreção vaginal}

Eritrocitos

$$
\square \text { ausentes } \quad 1+\quad \square 2+\quad \square 3+
$$

\begin{tabular}{lllll|l} 
Bacilos de Döderlein (Lactobacillus acidophilus) & $\square$ ausentes & $\square 1+$ & $\square 2+$ & $\square 3+$ & \\
Gardnerella vaginalis e Bacteróides sp & $\square$ ausentes & $\square 1+$ & $\square 2+$ & $\square 3+$ & $\square$ Escore $\geq 7$ \\
Bacilos Gram-negativos curvos (Mobiluncus sp) & $\square$ ausentes & $\square 1+$ & $\square 2+$ & $\square 3+$ & \\
"Clue cells" & $\square$ ausentes & $\square 1+$ & $\square 2+$ & $\square 3+$ & $\square$ Escore <7 \\
Difteróides & $\square$ ausentes & $\square 1+$ & $\square 2+$ & $\square 3+$ \\
Cocos Gram-positivos & $\square$ ausentes & $\square 1+$ & $\square 2+$ & $\square 3+$ \\
Diplococos Gram-negativos intracelulares & $\square$ ausente & $\square$ presente & \\
Trichomonas vaginalis & $\square$ Negativo & $\square$ Positivo & \\
Leveduras/hifas & $\square$ Negativo & $\square$ Positivo & \\
Outros & &
\end{tabular}

Cultura de Candida sp : $\square$ Não realizada $\square$ Negativa $\square$ Positiva

Cultura de Neisseria gonomhoea: [ Não realizada $\quad[$ Negativa $\quad[$ Positiva

Pesquisa de Clamídia por Imunofluorescéncia Direta: $[$ Não realizada $\square$ Negativa $\square$ Positiva

OBS.

Data do resultado: ' Responsável técnico: 


\section{RESULTADO DO EXAME CITOPATOLOGICO}

\section{Numero do Exame}

1-Dentro dos limites da Normalidadı II- Alteraçőes em células epiteliais

1] Sem células anormais

Em células escamosas

(1] Alteraçőes celulares benignas

[ inflamação

(]) Metaplasia escamosa

(] Reparaçăo

(] Atrofia com inflamação

[] Radiaçăo

1] Outros

(1) Atipias de significado indeterminado

(] Efeito citopático compativel com HPV

[ $\mathrm{NICl}$

[ NIC II

[] NIC III

(1) Carcinoma escamoso Em células glandulares

(1) Atipias de significado indeterminado

[. Adenocarcinoma "in situ"

(1) Adenocarcinoma invasor

Recebido em:

III- Microbiologia

L Lactobacilos

(1) Cocos

7 Bacilos

(1) Sugestivo de Chlamydia s;

(1) Actinomyces sp

1 Candida sp

1. Trichomonas vaginalis

4 Virus do grupo Herpes

[] Gardenerella vaginalis

7) Outros

\section{Leitura complementar}

A) Presença de leucócitos na endocérvice (porçăo distal da lâmina) observados, em aumento de 400X, em 5 campos nãoadjacentes, segundo os escores abaixo:

Q zero $=$ nenhum polimorfo

1+ =menos da metade das células do campo microscópico, estiver obscurecida por leucócitos

[ 2+ = quando mais da metade de células presentes no campo microscópico estiver obscurecida por leucócitos polimorfonucleares

B) células endocervicais reativas (isoladas, representadas por núcleos desnudos e aumentados)

Dpresentes $\square$ ausentes

C) células metaplásicas com vacúolos sem inclusర́es

Dpresentes $\square$ ausentes
IV- Amostra: [ Satisfatória
[ Satisfatória, mas limitada
Q Insatisfatória

Observaçő gerais:

Data do resultado: I 


\section{ANEXO 4.}

Quadro 1. Causas de vaginites

\section{Vaginite Infecciosa}

Causas mais freqüentes:

Vaginose Bacteriana (40-50\% casos).

Vulvovaginite por Candida sp (20-25\% casos).

Tricomoniase (15-20\% casos).

Causas menos freqüentes:

Vaginite atrófica com infecção bacteriana secundária.

Corpo estranho com infecção secundária.

Vaginite descamativa inflamatória (produzida por clindamicina).

Vaginite por Streptococcus (grupo A).

Vaginite ulcerativa associada com Staphylococcus aureus.

Vulvovaginite idiopática ulcerativa associada à AIDS.

Vulvovaginite viral (HVS, HPV).

\section{Vaginite Não-Infecciosa}

Vaginite traumática ou por agentes químicos e outros irritantes.

Alergia, hipersensibilidade e dermatite de contacto (líquen simples).

Vaginite atrófica pós-puberal.

Vaginite inflamatória descamativa (produzida por esteróides).

Líquen plano erosivo.

Enfermidades vasculares do colágeno, Síndrome de Behçet, Pênfigo.

Vaginite idiopática.

Fonte: Sobel 1997 
Quadro 2. Comparação dos sistemas de escores, desenvolvidos por Nugent e Spiegel, para o diagnóstico de vaginoses bacterianas, empregando-se o método de Gram.

\begin{tabular}{|c|c|}
\hline CRITÉRIOS DE NUGENT & CRITÉRIOS DE SPIEGEL \\
\hline $\begin{array}{l}\text { O sistema de escore varia de zero a } 7+^{*} \\
\text { A. Lactobacillus acidophilus (grandes } \\
\text { bacilos Gram-positivos) } \\
\text { B. Gardnerella vaginalis e Bacteroides } \\
\text { sp (pequenos bacilos Gram- } \\
\text { variaveis ou Gram-negativos) } \\
\text { C. Mobiluncus sp (pequenos bacilos } \\
\text { Gram-negativos curvos) } \\
\text { O escore final é a soma dos pesos } \\
\text { atribuídos para os três morfotipos } \\
\text { bacterianos descritos acima. } \\
\text { Escores para serem atribuidos de } \\
\text { acordo com o número de morfotipos } \\
\text { bacterianos, observados por campo de } \\
\text { 1000X, sob óleo de imersão: } \\
\text { Zero }=\text { nenhum morfotipo } \\
1+=\text { menos de 1morfotipo } \\
2+=1 \text { a } 4 \text { morfotipos } \\
3+=5 \text { a } 30 \text { morfotipos } \\
4+=\text { mais de } 30 \text { morfotipos } \\
\text { * A soma dos escores (A }+ \text { B }+ \text { C) } \\
\text { representa: } \\
\text { de zero a } 3 \rightarrow \text { flora normal; } \\
4 \text { a } 6 \rightarrow \text { flora indeterminada; } \\
7 \text { ou mais } \rightarrow \text { vaginose bacteriana }\end{array}$ & $\begin{array}{l}\text { Normal: predominância de Lactobacillus } \\
\text { acidophilus ( } 3+\text { ou } 4+) \text {, com ou sem } \\
\text { Gardnerella vaginalis. } \\
\text { Vaginose Bacteriana: flora mista } \\
\text { mostrando bactérias Gram-positivas, } \\
\text { Gram-negativas ou Gram-variáveis e } \\
\text { ausência ou decréscimo de L. } \\
\text { acidophilus (zero a } 2+\text { ). } \\
\text { A. L. acidophilus (grandes bacilos } \\
\text { Gram-positivos) } \\
\text { B. G. vaginalis (pequenos bacilos } \\
\text { Gram-variáveis) } \\
\text { Escores para serem atribuídos de } \\
\text { acordo com o número de morfotipos } \\
\text { bacterianos, observados por campo de } \\
\text { 1000X, sob óleo de imersão: } \\
\text { Zero }=\text { nenhum } \\
1+=\text { menos de 1morfotipo } \\
2+=1 \text { a } 5 \text { morfotipos } \\
3+=6 \text { a } 30 \text { morfotipos } \\
4+=\text { mais de } 30 \text { morfotipos }\end{array}$ \\
\hline
\end{tabular}

Fonte: Egan e Lipsky (2000) 